
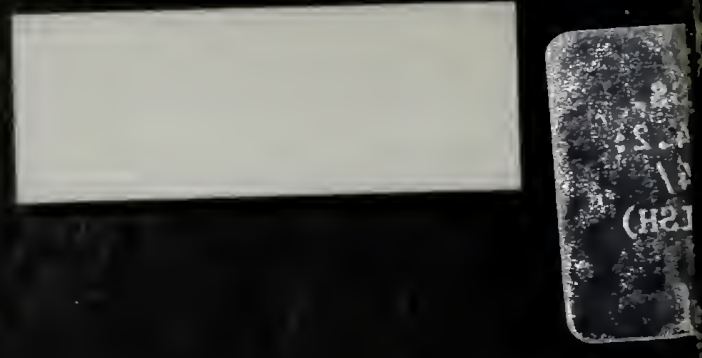


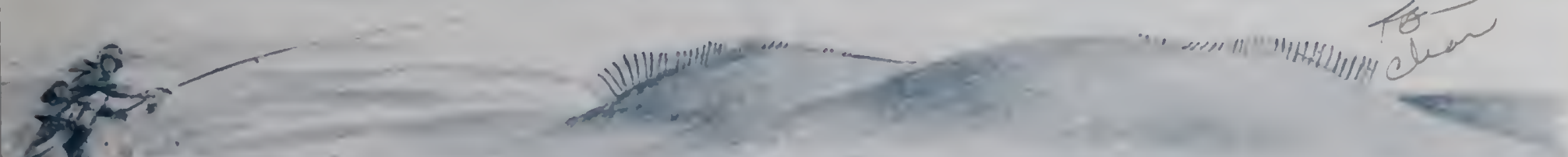

\section{Marine Recreational Fisheries of Massachusetts}

$$
\text { Bluefish }
$$

$\mathrm{T}$

he bluefish, a trophy species hotly pursued by anglers due to its reputation as a champion

battler and a voracious predator, is native to both the American and European-African

coasts of the Atlantic Ocean. Along the western Atlantic it is abundant from Argentibaituersipje of Miassachusetts Cod, and it occasionally occurs as far north as Nova Scotia.

Bluefish is something of a misnomer, as this species is most commonly a sea-green color above,

fading into a silvery shade on its lower sides and belly.

The adult blue-

fish has a stout body and a large mouth that extends posteriorly below and beyond the eye. The lower jaw juts out noticeably. Both the upper and lower jaws are fully armed with large, conically shaped canine teeth. The dorsal fin (A on diagram above) is divided into two sections. The first section, about half as long and high as the second, has a

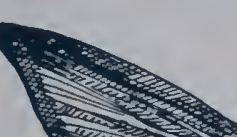

A

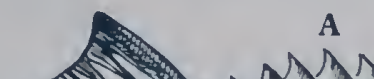
sh series of stiff spines supporting the soft tissues of the fin. The second or posterior dorsal fin is equal in length to the anal fin ( $\mathrm{B}$ above).

Bluefish rarely exceed 20 pounds and 40 inches in length. The North American record bluefish, caught in North Carolina, weighed 31 pounds 12 ounces. The Massachusetts record fish, landed at Graves Light in 1982, weighed 27 pounds 4 ounces. The larger fish caught during a given year generally run between $10-15$ pounds. The graph on the back page shows the relationship between the average weight and length of bluefish from 1 to 14 years of age.

Both male and female bluefish reach sexual maturity by the time they are 2 years old. The fecundity (number of eggs produced) of females is related to their size, with a 21 -inch female producing about 900,000 eggs and a 23 -inch female about $1,100,000$ eggs per year.

\section{Habits}

$\mathrm{B}$ luefish inhabit both inshore and offshore areas of coastal regions, with young-of-the-year fish (those in the first year of life), called "snappers," often frequenting estuaries and river mouths. This species normally travels in large schools, which may contain up to several thousand individuals. One unusually large school sighted in Narragansett Bay in 1901 was estimated to be spread over a 4 to 5 mile distance.

Bluefish display an annual migration pattern that is keyed to the seasonal warming and cooling of coastal waters. They begin arriving along the southern New England coast during April and May. The earliest catches in southern Massachusetts waters occur in mid-May, but substantial 
available, many types of cut bait also do well. Wire leaders are a must when bait fishing, in order to prevent a hooked bluefish from cutting the line with its sharp teeth.

Bluefish anglers fish from boat or shore along nearly every harbor entrance, town dock, beach, and jetty in the state. Cape Cod and the Islands (Martha's Vineyard and Nantucket), the Cape Cod Canal (particularly Sandwich and Sagamore), the Boston Harbor Islands, Marblehead, Manchester, Cape Ann up to Salisbury, Plum Island, and the mouth of the Merrimac River all attract a large number of anglers.

As with most fish, the quality of the flesh, and thus its flavor, will be best if the bluefish is gutted and iced as soon as possible after capture. The soft-textured bluefish flesh has a high oil content. When concentrated, fish oils (recently discovered to be of great importance in maintain-

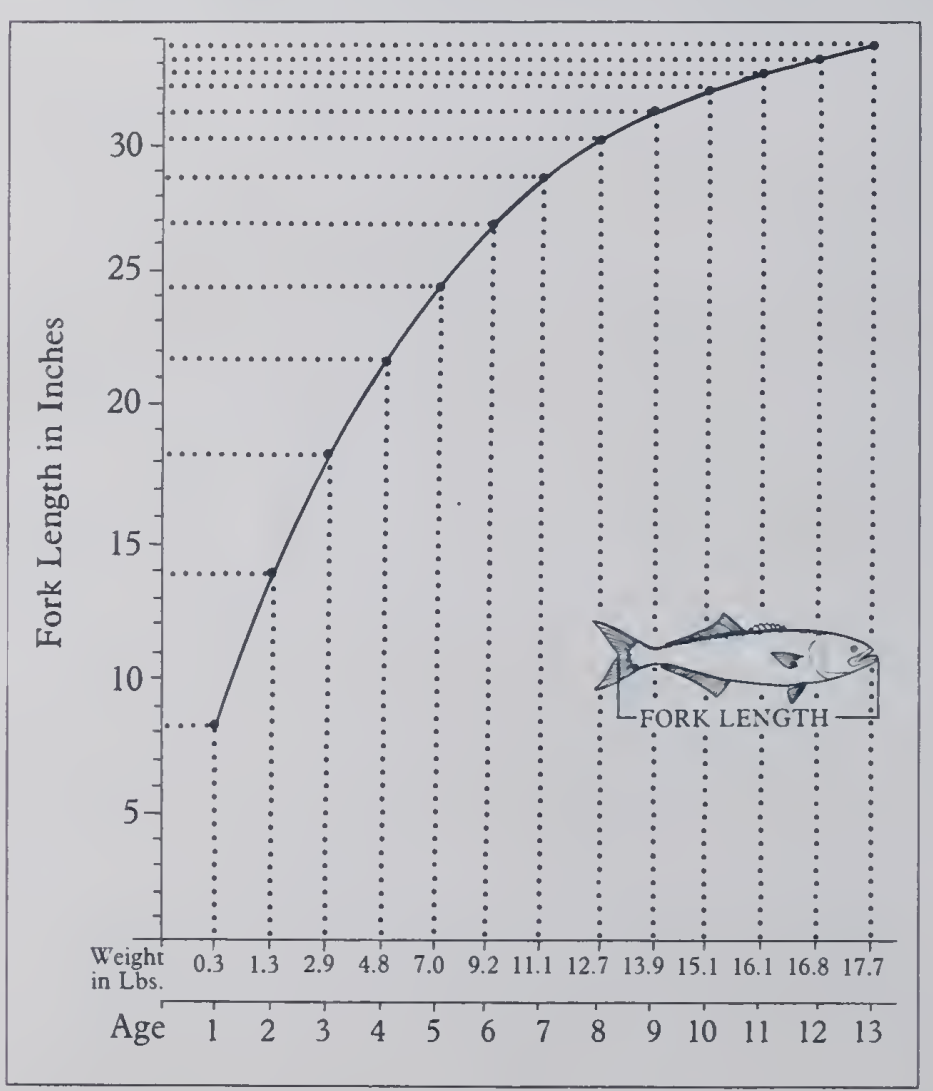
ing human cardiovascular health) can create a strong flavor that is not favored by many people. Bluefish fillets can be marinated in acidic foods such as vinegar, lemon or lime juices, or wine, or they can be cooked with fresh vegetables such as tomatoes and onions. These methods will lighten the flavor as well as retain the oils that confer the full health benefits associated with eating fish.

Michael R. Ross

Department of Forestry and Wildlife Management

University of Massachusetts

Robert C. Biagi

Cooperative Extension

University of Massachusetts

Supported by Federal Aid in Sport Fish Restoration Act, through the Massachusetts Division of Marine Fisheries, Department of Fisheries, Wildlife, and Environmental Law Enforcement, Executive Office of Environmental Affairs.

Produced by Cooperative Extension Communications Center. Liz Scott, design; Nancy Haver, Roy Lewando, illustration. University of Massachusetts, United States Department of Agriculture, and Massachusetts counties cooperating. Issued by E. Bruce MacDougall, Dean, in furtherance of the Acts of May 8 and June 30, 1914. Cooperative Extension offers equal opportunity in programs and employment. When a product name is mentioned, no discrimination is implied against similar or equivalent products. CR60:12/87-10M

This publication is part of the Marine Recreational Fisheries series, available from the Division of Marine Fisheries, 100 Cambridge Street, Boston, MA 02202. 


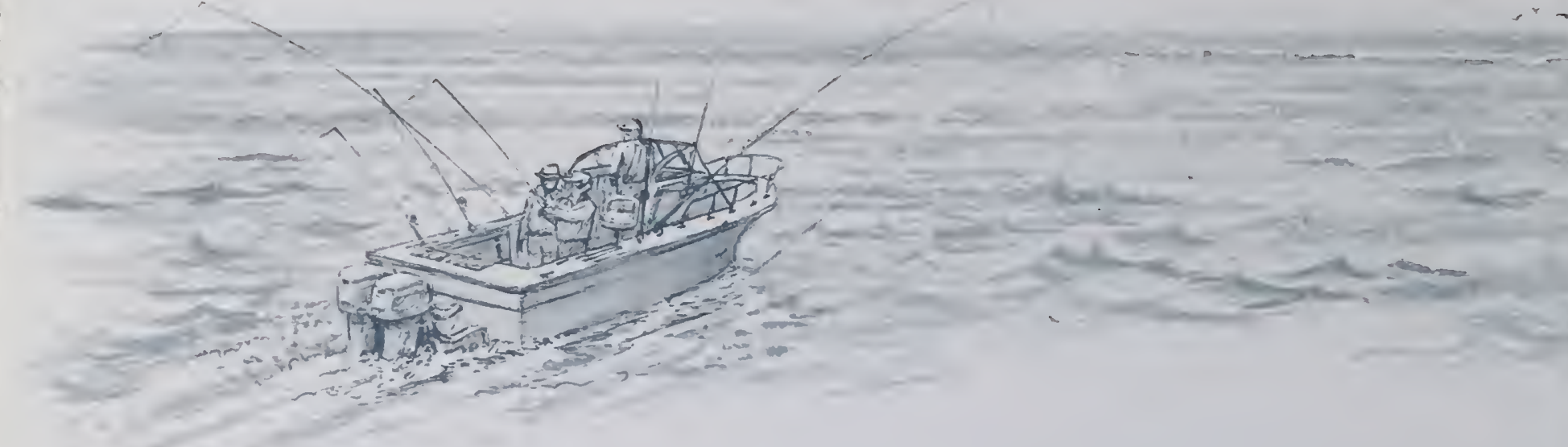

are known to travel extensively between Nantucket Shoals and Cape Hatteras at depths to nearly 1100 feet. In the spring this species displays a general northward and inshore movement, expanding its range as far north as Cape Cod from May to October. During the summer, adult sea bass gather around rocky bottoms, sunken wrecks, old pilings, and wharves. At this time of year they are most abundant at depths of less than 120 feet. Young-of-the-year and yearlings tend to summer in estuaries, which are critically important nursery grounds for this species. In southern Massachusetts, young-of-the-year start to enter estuaries in August and move offshore to depths of from 180 to 360 feet during the fall. The largest adults in southern New England tend to begin their annual offshore and southerly migration as early as August, while juveniles and smaller adults migrate later in the fall.

Black sea bass reproduce from February to July, with the spawning season starting earliest in the southern portion of their range and progressing northward as spring passes. Off the southern New England coast, they reproduce from mid-May until the end of June. The eggs are buoyant, floating in the water column until they hatch $1 \frac{1}{2}$ to 5 days after fertilization. The larvae drift in bays, inlets, and offshore areas; they become bottom-dwelling when they have grown to about $1 / 2$ inch in length.

Juvenile and adult black sea bass feed upon a variety of benthic (bottom-dwelling) invertebrates such as rock crabs, hermit crabs, squids, and razor clams.

\section{Management}

$\mathrm{T}$ he abundance of black sea bass along the East Coast has been declining for over three decades. Furthermore, the average size fish harvested both commercially and recreationally has been decreasing since about 1950, indicating that larger, older fish have become increasingly scarce.

Commercial harvests have been based upon otter trawl and wooden pot (similar to a lobster trap) fisheries. Annual landings from trawlers are typically greatest from September to March, when black sea bass are distributed more of fshore than in summer months. The total annual catch from trawl fisheries peaked in the early 1950s. Yearly landings for the entire mid-Atlantic region peaked at nearly $21,000,000$ pounds in 1952, and then plummeted to less than $5 \%$ of that level by 1970.

Pots are fished from spring through late fall, enabling fishermen to harvest sea bass in areas where rugged underwater terrain makes trawling ineffective. Pot fisheries developed rapidly along much of the East Coast in the 1950s. After an initial period of annual increases in harvest, pot fisheries have usually declined fairly rapidly even when the number of pots fished continued to increase. Data from the New York State pot fishery clearly exhibit this trend. In 1961, a total of 400 pots harvested 77,000 pounds of black sea bass in New York's waters. In 1965, a five-fold increase in the number of pots fished produced only 2.4 times as great a catch. By 1967, over 40 times as many pots produced a catch that was $17 \%$ smaller than in 1961, and by 1971 catch levels were $37 \%$ 


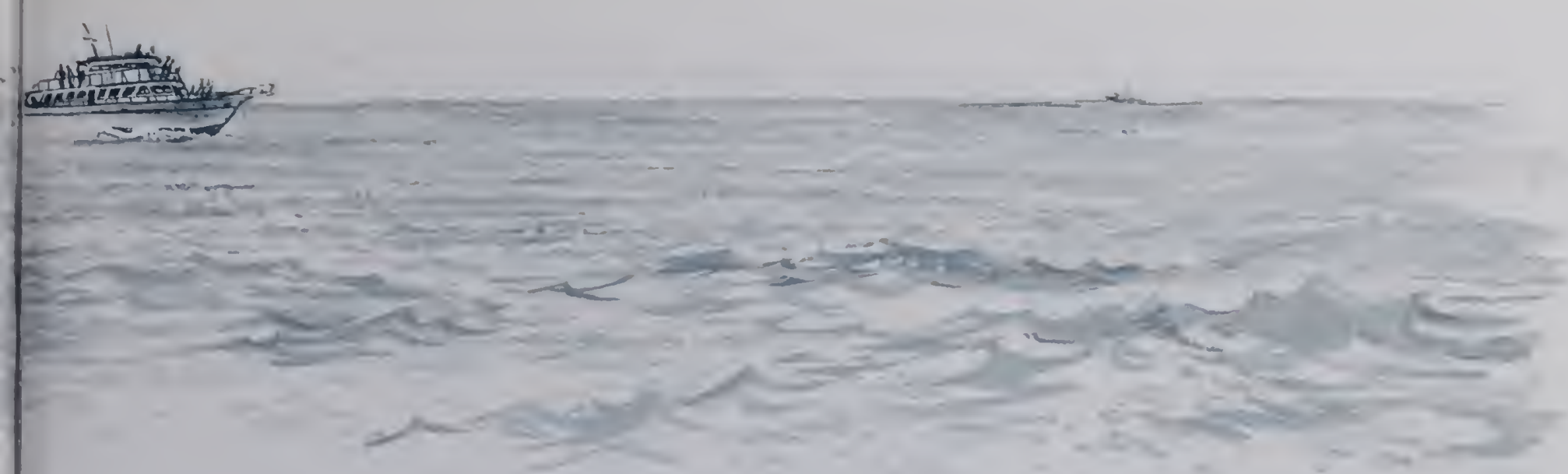

lower than in 1961. The pot fishery off Massachusetts developed more recently than in other more southerly waters, but has been expanding rapidly over the last five years, particularly in Nantucket Sound. This expansion has caused increasing concern over issues of overharvest and gear conflict in Massachusetts waters.

The recreational fishery has added to the decline in population abundance along the Atlantic Coast. In 1965 over half of the total catch of black sea bass was credited to recreational fishing. One survey indicated that, by 1970 , the recreational catch was at least several times as great as the commercial harvest. Angling pressure has increased markedly in recent years. In the north Atlantic region, including Cape Cod, recreational harvest increased nearly 500 percent between 1981 and 1986. Over the same time period, recreational harvest increased about 1400 percent in the mid-Atlantic region. From Cape Hatteras to Nova Scotia, harvest increased from $8,100,000$ to $31,200,000$ fish between 1985 and 1986; in 1986, the black sea bass ranked second to scup in numbers harvested recreationally in that geographic area. As with the commercial fisheries, the average size of fish caught by anglers has decreased in recent years. The average size black sea bass caught in 1986 was 9 to 10 inches in length.

The expansion in both the pot fishery and the level of recreational harvest in recent years led the Massachusetts Division of Marine Fisheries to establish a minimum legal size limit (12 inches in 1987) to protect this valuable fishery in Massachusetts waters.

$\mathrm{W}$

\section{Angling and Handling Tips}

hen many anglers hear someone mention "bass," they often think first of stripers or freshwater black bass. Yet the black sea bass provides a fight and a flavor that attract a strong angler following. Long known by commercial fishermen as "rock bass," this species also carries the somewhat endearing name of "old humpback," due to the enlarged area above the head that is characteristic of many old males.

The best time to fish for black sea bass is from May through summer, when they are closest to shore. Any underwater structures, such as those associated with wrecks, jetties, and piers, will attract this species. Although they can be found from near shore to depths of about 120 feet, the
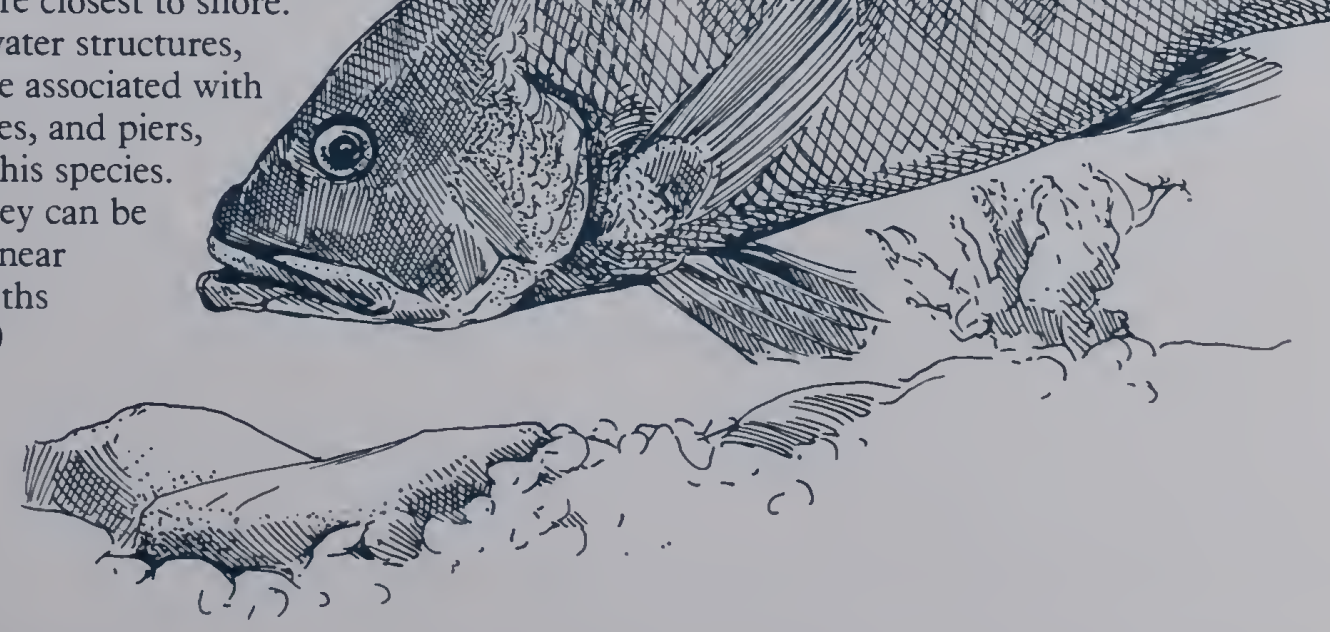


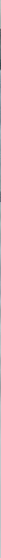

largest males tend to be found in deeper waters within this depth range.

The black sea bass is predominantly a bottom-feeder, although it will occasionally strike at plugs, jigs, or lures. Thus, bait fishing with strips of squid or fish is the most productive method. The most commonly caught fish weigh from $1 / 2$ to 2 pounds. You can receive the greatest enjoyment when catching fish in this size range by using a medium-weight spinning outfit with 8 -pound test line. Although a sea bass has a large mouth, use a $\# 2$ bait-holder hook tied above a small sinker; this fish normally hesitates to grab bait strung on large cod hooks.

The firm, white flesh of this species is a favorite of many. Bass are easy to fillet, especially when chilled, and yield a thick slice of meat. Some fillets are thick enough to slice lengthwise or to cut into nuggets for frying. Larger fish can be cut into steaks and cooked like striped bass. In restaurants, black sea bass are often offered as "squirrel fish," and Chinese restaurants will serve delicious whole deep-fried bass as "Hunan fish."

Try broiling black sea bass fillets. When broiling, fold under the thin section from the tail area to allow more even cooking. Place the fish in a greased pan, sprinkle with fresh ground pepper and paprika, and dot with butter or olive oil. Broil 5 to 6 minutes on each side, depending upon thickness, until the fillets are golden-brown. Be careful not to cook too long, as the fillets will dry and become somewhat leathery.

Michael R. Ross and Laura A. Thorpe

Department of Forestry and Wildlife Management

University of Massachusetts

Robert C. Biagi

Cooperative Extension

University of Massachusetts

Supported by Federal Aid in Sport Fish Restoration Act, through the Massachusetts Division of Marine Fisheries, Department of Fisheries, Wildlife, and Environmental Lazo Enforcement, Executive Office of Environmental Affairs.

Produced by Cooperative Extension Communications Center. Liz Scott, design; Nancy Haver, Roy Lewando, illustration. University of Massachusetts, United States Department of Agriculture, and Massachusetts counties cooperating. Issued by E. Bruce MacDougall, Dean, in furtherance of the Acts of May 8 and June 30, 1914. Cooperative Extension offers equal opportunity in programs and employment. When a product name is mentioned, no discrimination is implied against similar or equivalent products. CR60:12/87-10.M

This publication is part of the Marine Recreational Fisheries series, available from the Division of Marine Fisheries, 100 Cambridge Street, Boston, MA 02202. 


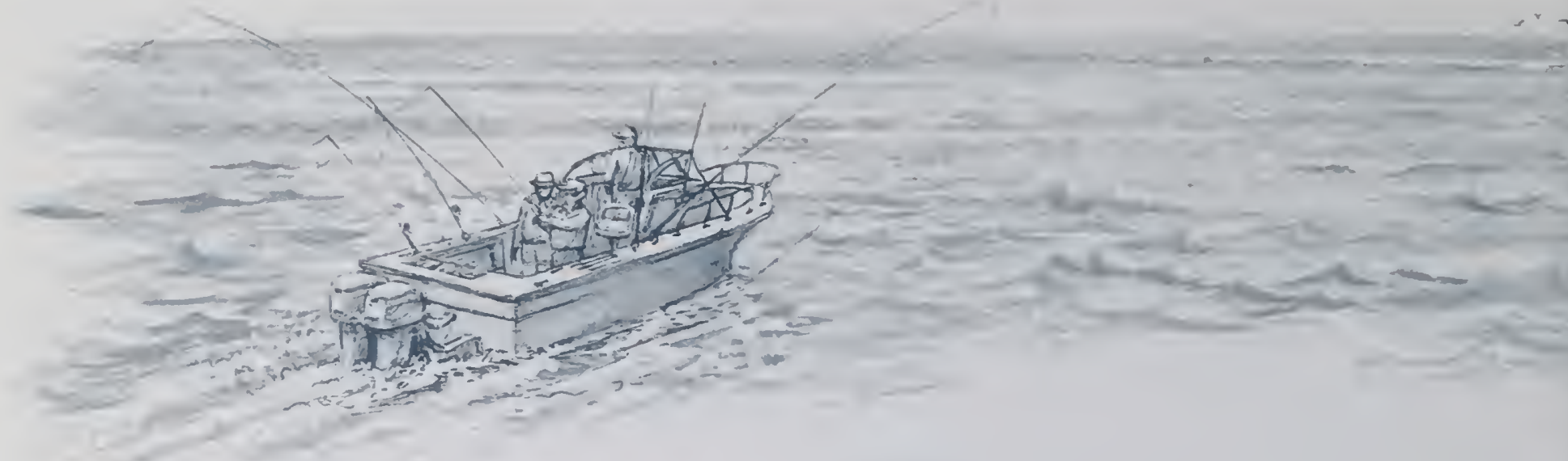

\section{Habits}

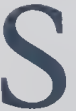

triped bass are rarely found more than several miles from the shoreline. Anglers usually catch stripers in river mouths, in small, shallow bays and estuaries, and along rocky shorelines and sandy beaches. The striped bass is a schooling species, moving about in small groups during the first two years of life, and thereafter feeding and migrating in large schools. Only females exceeding 30 pounds show any tendency to be solitary.

Schools of striped bass less than three years of age (sometimes called "schoolies" by anglers) occasionally travel far upstream into rivers such as the Hudson, Connecticut, and Merrimac. Although adult striped bass move into rivers to reproduce, fish less than three years old probably make such journeys to take advantage of a river's abundant food resources.

Striped bass normally do not migrate during the first two years of life. However, adult stripers generally migrate northward in the spring and summer months and return south in the fall. Individuals that hatch in the Hudson River generally do not migrate beyond Cape Cod to the north and Cape May to the south. Fish hatched in the Chesapeake Bay exhibit more extensive migrations, some being captured as far north as the Bay of Fundy in coastal Canada.

Stripers are strictly spring to fall transients in Massachusetts. Only a few fish inhabiting coastal Massachusetts waters in the summer have been known to overwinter in the mouths of southern New England streams. Some stripers frequenting coastal Massachusetts in the summer will overwinter in the mouth of the Hudson River, while many spend winter along the New Jersey coast or in the Delaware and Chesapeake Bays.

Stripers reproduce in rivers and the brackish areas of estuaries. Spawning occurs from the spring to early summer, with the greatest activity occurring when the water warms to about 65 degrees $F$. The eggs drift in currents until they hatch $1 \frac{1}{2}$ to 3 days after being fertilized. Because newly hatched larvae are nearly helpless, striped bass suffer their highest rate of natural mortality during the several weeks after hatching.

The major spawning activity for the entire East Coast fishery occurs in the Hudson River, the Chesapeake Bay, and the Roanoke River-Albermarle Sound watershed. Striped bass are most abundant in the New England and mid-Atlantic states following years when reproduction in the Chesapeake Bay has been particularly successful, suggesting that much of the East Coast is strongly dependent upon the success of spawning in that one watershed.

Striped bass eat a variety of foods, including fish such as alewives, flounder, sea herring, menhaden, mummichogs, sand lance, silver hake, tomcod, smelt, silversides, and eels, as well as lobsters, crabs, soft clams, small mussels, annelids (sea worms), and squid. They feed most actively at dusk and dawn, although some feeding occurs throughout the day. During midsummer they tend to become more nocturnal. Stripers are particularly active in areas with tidal and current flows and in the wash of breaking waves along the shore, where fish, crabs, and clams become easy prey as they are tossed about in the turbulent water.

\section{Management}

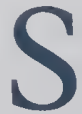

triped bass populations have a history of periods of abundance interspersed with periods of scarcity. A major coast-wide reduction in abundance occurred at the end of the 19th century. No catches of stripers were reported north of Boston for 30 years after 1897. Populations had recovered somewhat by 1921, and an unusually successful year of reproduction in 1934 was followed by 6 years of markedly increased abundance. Great numbers of juvenile fish were recorded in Massachusetts waters in the mid-1940s, and high numbers of increasingly larger individuals followed for a period of years. Such information suggests that striped bass populations are dominated for extended periods by fish hatched 


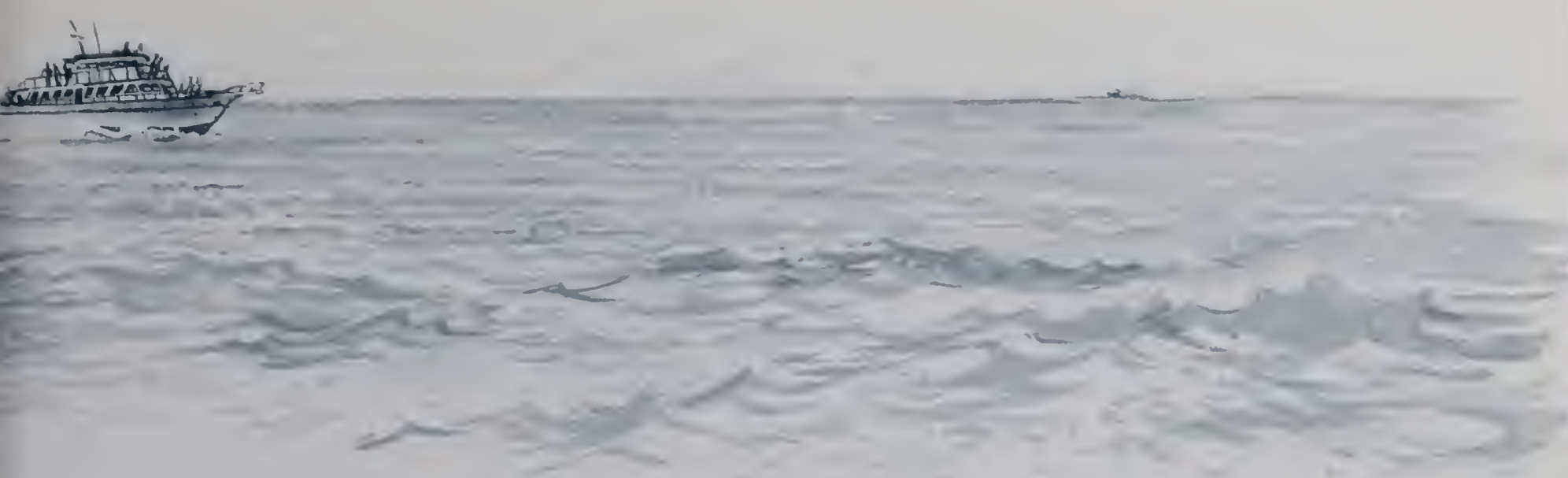

during occasional years of unusually successful reproduction. Also, a year of successful reproduction is often followed by a series of years when spawning fails or is so limited in success that relatively few new fish enter the population. The last peak year of reproductive success in the Chesapeake Bay was 1970 (note figure). Levels of reproduction have been consistently low since then; 1982 represents the only year

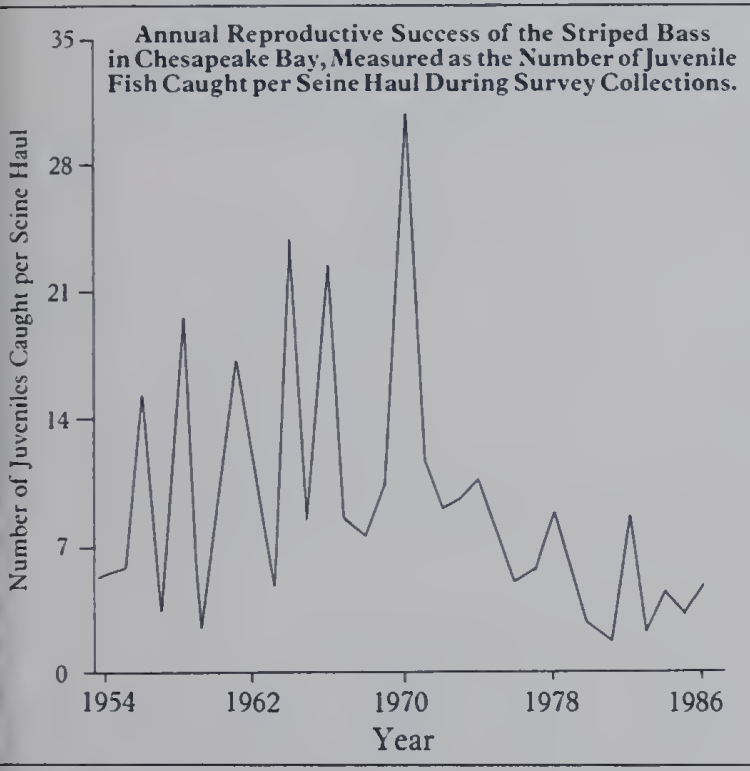
in this decade in which even modest numbers of juveniles have been produced. Thus, most of the bass harvested in the last ten years have come from the spawning effort of 1970. The recent extremely prolonged period of reproductive failure has caused a steady decline in striped bass abundance. This decline has been reflected in decreasing success by anglers. For example, the estimated catch by anglers from the Gulf of Maine to the mid-A tlantic region fell from $6,600,000$ pounds in 1979 to $1,700,000$ pounds in 1985 .

The decline in the abundance of stripers coming from the Chesapeake Bay is felt to be caused by a combination of factors, including the presence of a variety of pollutants in spawning grounds, fishing pressure, and feeding and nutritional problems of larvae.

A rapidly changing management plan has been developed in response to the severely depleted status of the striped bass. Prior to the mid-1970s, management of striped bass was carried out more or less independently by each coastal state. In 1979, Congress amended the Anadromous Fish Act to create the Emer-

gency Striped Bass Study Program. In 1981, the Atlantic States Marine Fisheries Commission (ASMFC) adopted a coastwide management plan, to be acted upon by each coastal state. This plan recommended minimum size limits for fish caught in nursery rivers and in coastal areas, and restricted fishing on spawning grounds during the spawning season. In response to constantly dwindling numbers of stripers on the East Coast, this plan was amended in 1984 to reduce the number of fish harvested by an additional $50 \%$, and further amended in 1985 to protect females hatched in 1982 until they have spawned at least once. This last amendment proposed a minimum size limit of 33 inches for the fall of 1987, which corresponds to the size at which most females have reached sexual maturity. In cooperation with this amended coastwide plan, the Massachusetts Division of Marine Fisheries established closed seasons to commercial harvest and a one fish per day recreational catch and possession limit in 1984, and increased the minimum legal size limit to 33 inches for 1987. Congress recently extended the Atlantic Striped Bass Conservation Act, which requires all coastal states to abide by provisions of the amended ASMFC Management Plan.
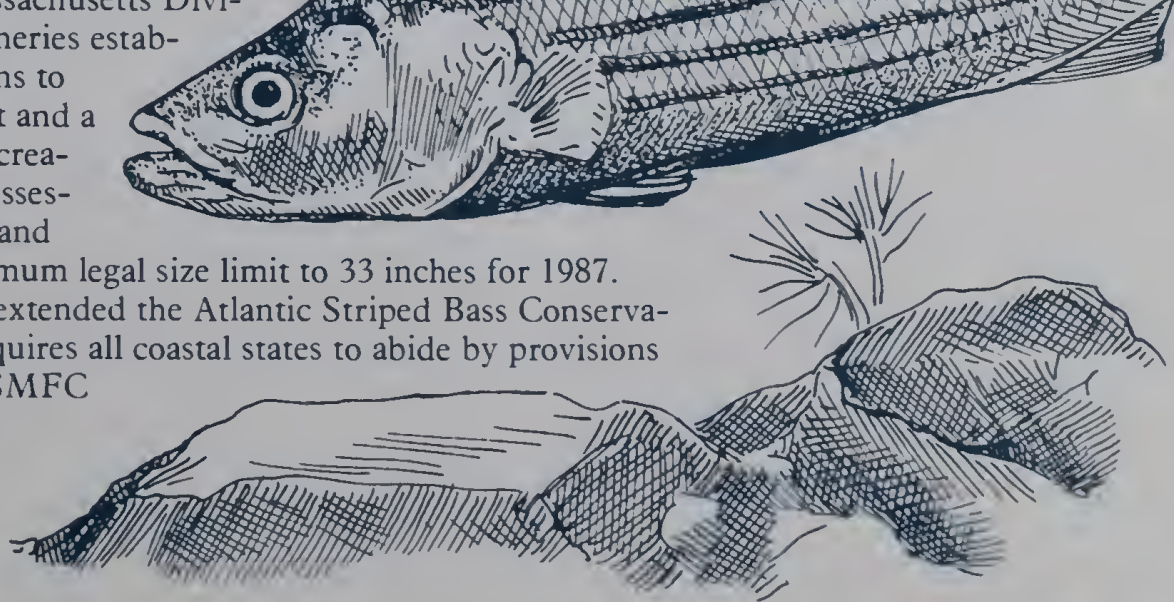


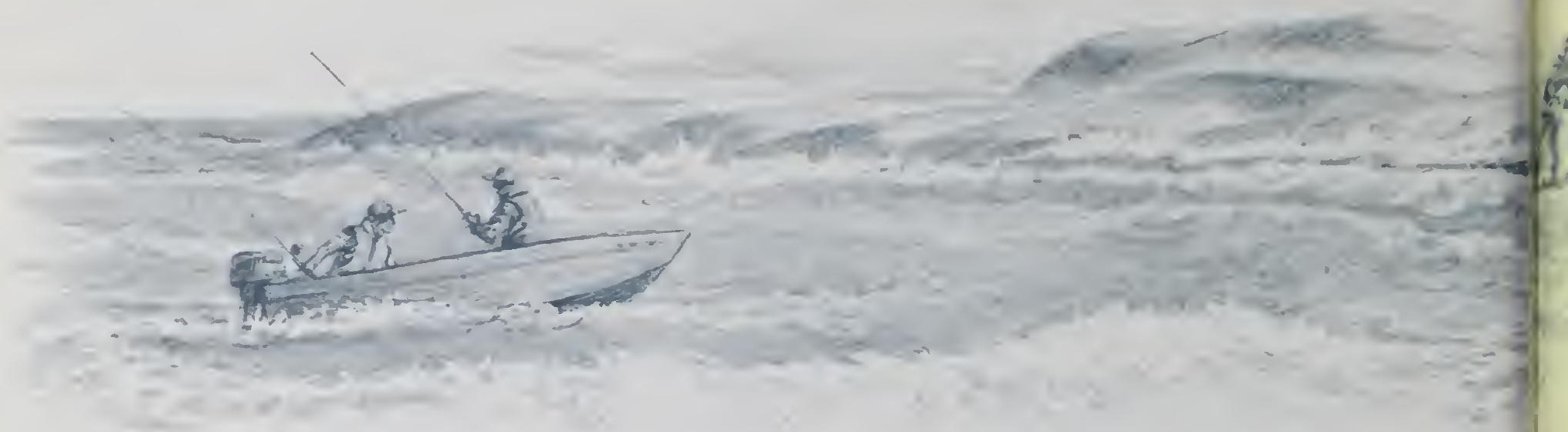

Meanwhile, a new management plan currently in preparation is to become effective when striped bass populations are restored to more desirable levels. Unlike the existing plan, which can only effect changes through a lengthy amendment process, the new plan is expected to identify a range of management options that can be considered as changing population levels dictate.

\section{Angling and Handling Tips}

$\mathrm{T}$

he striped bass is so highly prized for its size, battle on the line, and culinary merit, that many anglers consider it the premier game fish in Massachusetts. This species can be found from May to November along the entire Massachusetts coastline. Angling at dusk or dawn provides the greatest success during most of the season, but night fishing is often best during the midsummer "doldrums." Anglers are most successful when fishing the shoreline in areas where tidal rips, strong currents, or wave action create turbulent, "live" water.

Some anglers who ply the beaches with swimming plugs and live eels, prefer the 10- to 12-foot surf rod and conventional reel spooled with 30 - to 40 -pound line. However, a medium to heavy spinning rod with 12- to 20-pound test line is considered ideal by many anglers for plugging, jigging, or offering bottom-fished baits to bass. Lures are attached directly to the line with a snap swivel. When bait fishing, the preferred rig consists of a pyramid sinker attached as a fish finder, and a long leader with a brightly colored float attached close to the hook. The float keeps the bait away from bottom-dwelling crabs and skates.

Live lining of "herring," menhaden (pogies), or mackerel can be a very productive means of taking large bass. A fairly stiff boat rod with a conventional reel is the preferred rig. Bait fish are hooked through the back or snout using either a single or treble hook.

When trolling for bass adjacent to shoreline areas, the rod should be equipped with a high-ratio conventional reel and carboloy guides to prevent line wear. By choosing among monofilament, lead-core or wire lines, depths from the surface to the bottom can be trolled. Many lures, including swimming plugs, jigs, tubes, and umbrella rigs - as well as live herring and menhaden-lend themselves well to trolling for stripers.

Large bass can be steaked, then baked, broiled or grilled. If steaks are cut particularly thick, they can be stuffed with slices of bacon, onions, tomatoes, green peppers, parsley, apples, and even cranberries, and spiced to taste. Place the lightly-floured fish in a foiled baking dish, add one cup of mild red wine and bake at 400 degrees until the flesh flakes.

Michael R. Ross

Department of Forestry and Wildlife Management

Robert C. Biagi

Lniversity of Massachusetts

Cooperative Extension

U'niversity" of Massachusetts

Supported by Federal Aid in Sport Fish Restoration Act, through the Massachusetts Dizision of Marine Fisheries, Department of Fisheries, W'ildlife, and Enzironmental Laz' Enforcement, Executite Office of Encironmental Affairs.

Produced by Cooperative Extension Communications Center. Liz Scott, design; Nancy Hater, Roy Lewando, illustranon. L'niversity of Massachusetts, L'nited States Department of Agriculture, and Massachusetts counties cooperating. Issued by E. Bruce. MacDongall, Dean, in furtherance of the Acts of May 8 and June 30, 1914. Cooperatize Extenston offers equal opportunity in programs and employment. W'hen a product name is mentioned, no discrimination is implied against similar or equizalent products. CR60:12/87-10.11

This publication is part of the Marine Recreational Fisheries series, available from the Division of Marine Fisheries, 100 Cambridge Sireet, Boston, MA 02202 


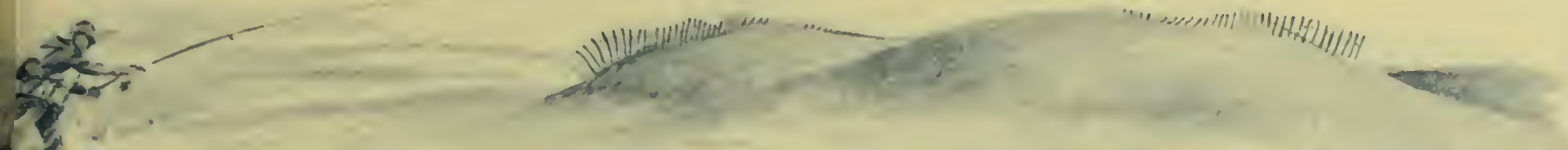

\section{Marine Recreational Fisheries of Massachusetts Atlantic

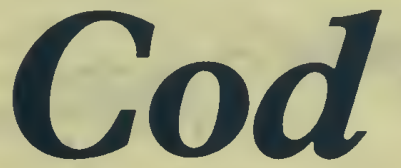

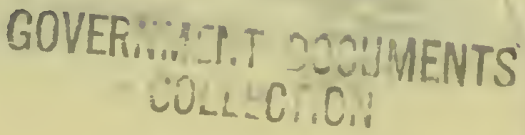

$\mathrm{P}$

erhaps more than any other member of Massachusetts' rich array of natural resources, the Atlantic cod is recognized as a symbol of the Commonwealth's natural heritage. This species, so entwined in the early history of settlement of coastal Massachusetts that a model (referred to as the "Sacred Cod") hangs in the statehouse, is native to most of the North Atlantic Ocean. In the northwest Atlantic it inhabits waters from western Greenland south to Cape Hatteras, North Carolina, and is most abundant from the coast of northern Labrador to the Nantucket Shoals region off Massachusetts.

Cod are easily distinguished from most other marine fish by their three rounded dorsal fins (A on diagram above) and two anal fins (B above) that are mirror images of the second and third dorsals. They also have a prominent barbel ("whisker") on the chin.
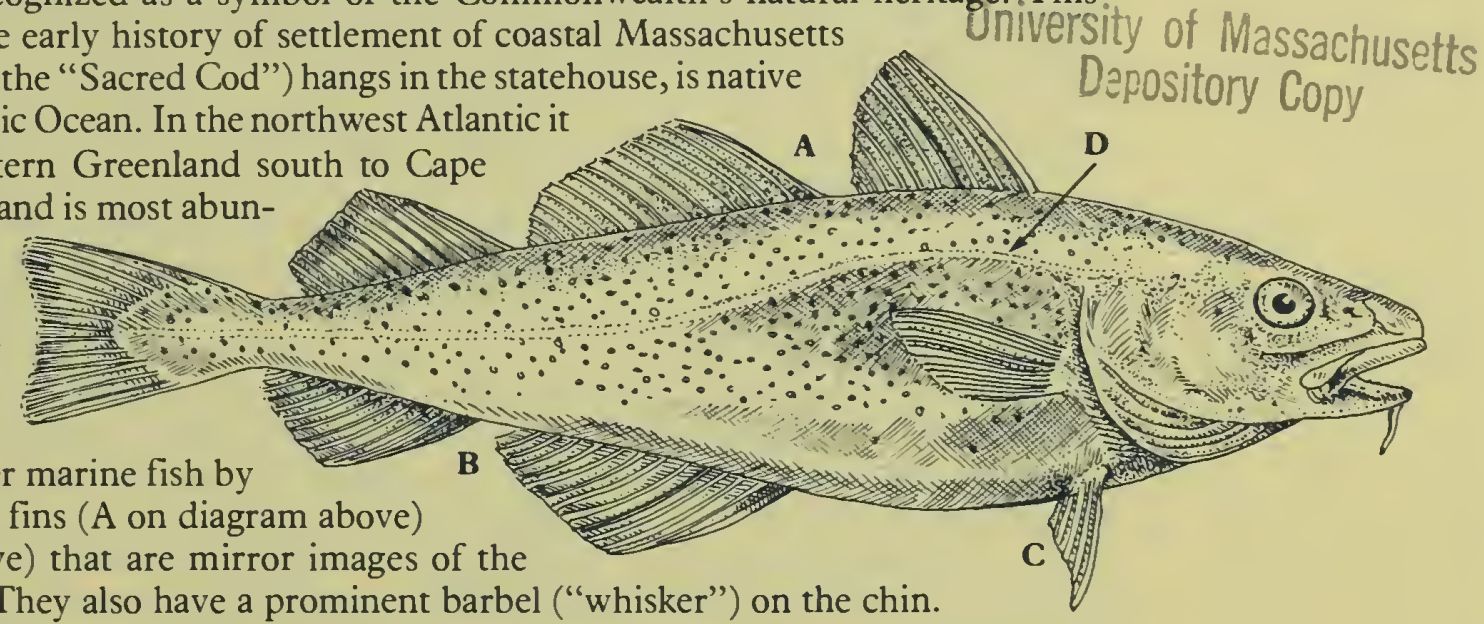

Cod lack the large dark blotch on the side that is characteristic of the closely related haddock. The square or indented outline of the cod's tail differs from the rounded tail of the tomcod. The cod also lacks the slender, elongate extensions of the pelvic fins (fins marked $\mathrm{C}$ above) characteristic of the tomcod.

Individuals vary widely in color. Most cod are grayish green to reddish brown on their backs and sides, and white on their bellies. They are speckled on the upper portion of their bodies, the sides of their heads, and their fins and tails. The lateral line ( $D$ above), a series of pores that allows fish to detect disturbances in the water, is conspicuously lighter than the dark sides of the body.

Cod occasionally reach lengths in excess of 5 to 6 feet. The heaviest fish on record, caught off the Massachusetts coast by a commercial vessel, weighed over 200 pounds. The Massachusetts angling record was set by a fish weighing 85 pounds 10 ounces, boated on Jeffries Ledge in 1984. In recent years, harvested cod very rarely weigh more than 100 pounds, with 50 - to 60 -pound fish normally the largest sizes taken. Offshore cod tend to be larger than inshore ones, the former frequently reaching sizes of 25 pounds and 40 to 42 inches in length while the latter usually weigh 6 to 12 pounds and measure 27 to 34 inches in length. One-year-old fish are typically 7 to 12 , 2 -year-olds 14 to 17 , and 3-year-olds 19 to 22 inches in length.

Both sexes usually reproduce for the first time when 5 or 6 years old. The fecundity (number of eggs produced in a given year) of females increases with size and age. A 40-inch female may lay about 3 million eggs, and a 50-inch female up to 9 million eggs in one spawning season. 


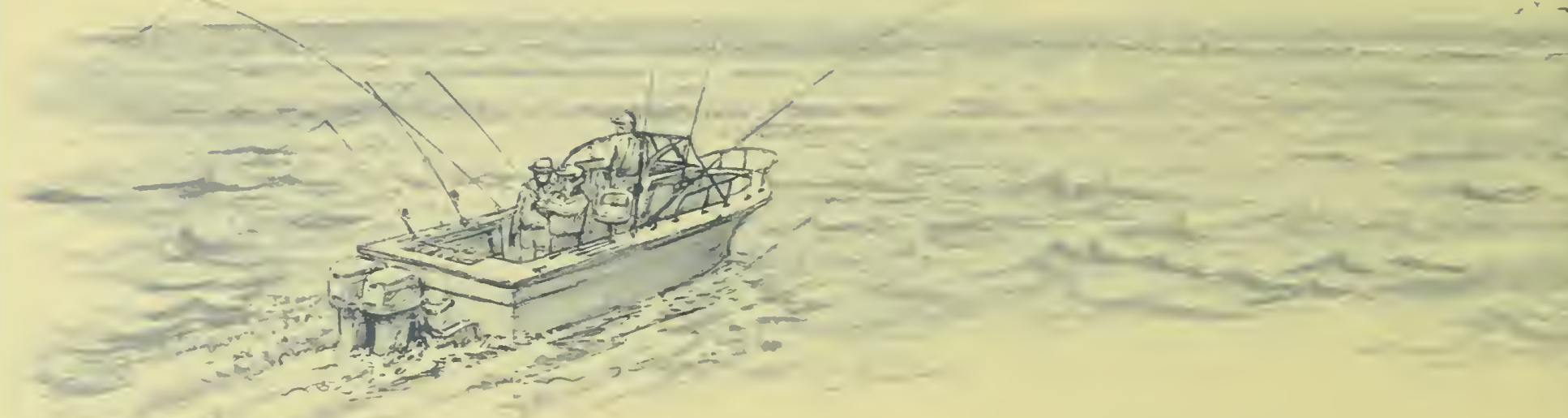

\section{Habits}

$\mathrm{A}$ tlantic cod live in a variety of habitats but generally are found at depths of 200 to 360 feet and in temperatures ranging from 34 to 46 degrees $F$ in the summer, and at depths of 295 to 440 feet and in temperatures of 36 to 39 degrees $F$ in the winter. They seldom are found deeper than 660 feet.

Cod undergo seasonal migrations in the more northerly and southerly reaches of their range in the northwest Atlantic. Those fish inhabiting polar waters in the summer and autumn migrate to more southerly and deeper waters in winter and spring, while fish summering in the Nantucket Shoals region overwinter along the New Jersey coast. Fish inhabiting the region between coastal Nova Scotia and Cape Cod do not exhibit predictable seasonal migrations. Some move considerable distances in search of food or in response to overcrowding at certain spawning grounds, but generally adults in our region remain within limited areas of uniform physical conditions. Cod do not swim about in large schools, but they do travel in small groups when searching for food.

The cod is a winter spawner. It reproduces from November to December along the coast of southern New Ento 350 feet, with the greatest activity occurring in about 200 feet of water. Adults inhabiting inshore areas generally move offshore to reproduce.

Larvae measuring about 0.2 inches hatch from 10 to 40 days after spawning, depending upon water temperatures. The larvae inhabit the open water column feeding upon microscopic copepods for 2 to 3 months after hatching. Then they move to the bottom where they hide and feed among rocks and algae until they are large enough to swim away from predators.

The smaller bottom-dwelling cod feed mainly upon small crustaceans such as shrimp and amphipods. Adults will eat almost anything small enough to fit into their mouths, including clams, cockles, mussels, and other mollusks, as well as crabs, lobsters, and sea urchins. Adults also pursue schooling fish, eating substantial numbers of herring, capelin, shad, mackerel, silver hake, young haddock, and other species. Voraciously pursuing a variety of potential food, cod will occasionally dine upon some very exotic items; ducks, shoes, jewelry, and rope have been found in the stomachs of captured cod.

Young cod are eaten by many species of fish, including pollock and larger cod. Once juvenile cod grow to about 8 inches, they can effectively swim away from many of their potential predators. Adult cod occasionally fall prey to spiny dogfish and sharks. 


\section{Management}

$\mathrm{T}$

he cod has been an extremely valuable resource for several centuries in Massachusetts. Its extensive use as a food dates back to the earliest period of European settlement in coastal New England. In colonial times, it was deemed so important that in 1639 the General Court of the Massachusetts Bay Colony ordered that cod could no longer be used as fertilizer by farmers. This action was one of the first recorded attempts at natural resource conservation and management on this continent.

Although one of the earliest fisheries resources to be broadly utilized after European settlement in New England, cod populations along the U.S. coast proved to be very resilient. Cod apparently withstood more than 3 centuries of harvest without displaying major, long-term reductions in abundance. However, mid-twentieth century advances in fishing technology and the introduction into the northwest Atlantic of distant-water foreign fishing fleets during the late 1950s led to a period of reduced abundance and major annual fluctuations in population size. During the mid- 1980 s commercial vessels captured mostly 3 -to- 5 year-old fish, indicating that few larger, older individuals remain along the North American coast.

Recreational harvest constitutes a modest portion of the total cod landed. From 1979 to 1984, recreational harvest averaged about $13 \%$ of the total cod harvest in the Gulf of Maine, and about $10 \%$ on Georges Bank and areas to the south.

Cod harvest in the Fishery Conservation Zone (FCZ; 3 miles to 200 miles from the shoreline) falls under the Northeast Multispecies Fishery Management Plan of the New England Fisheries Management Council. Regulations under this plan include minimum legal size limits for commercial and recreational harvest (17 inches for the latter), area closures, and mesh size regulations for commercial trawl nets. In Massachusetts territorial waters, the Massachusetts Division of Marine Fisheries has established minimum legal size limits (15 inches for recreational fishing and 19 inches for commercial fishing for 1987) to protect the spawning potential of cod populations. In the fall of 1987, a proposal was under consideration to increase the minimum size limit for the recreational fishery in inshore areas to 17 inches in order to standardize regulations with those in the FCZ.

\section{Angling and Handling Tips}

$M$ any anglers fish for cod on offshore grounds in private or party boats. A $71 / 2$ - to 9 -foot medium to stiff rod with a conventional $4 / 0$ reel is required when pursuing this species offshore. The reel should be spooled with 50 -pound test dacron line. Many of the most successful anglers use jigs with teasers. Ten- to 20 -ounce Vike or Norwegian-style jigs are popular; some anglers prefer to replace the treble hook on such lures with a 10/0 or larger hook that has a red surge tube over the shank. Jigs should be tied to a monofilament leader fastened to the rod's line by a black swivel. The lure is completed by attaching a red, green, black, or white tube teaser worm on 


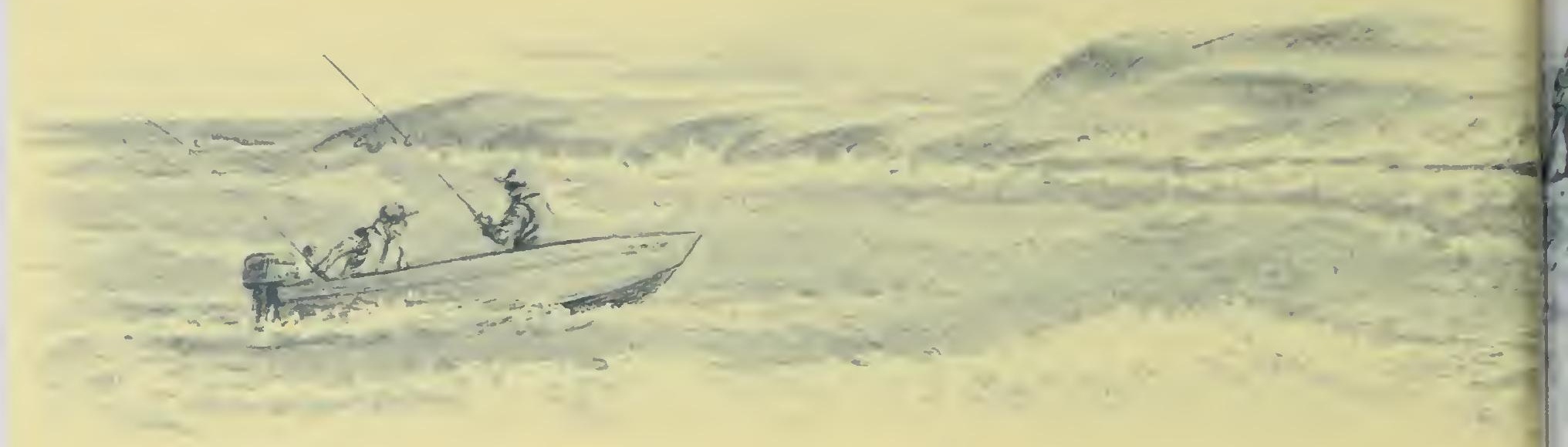

a large $8 / 0$ hook to the swivel. Such a rigging resembles a large fish chasing smaller bait fish, an effect that causes many fish to strike at the teaser being "chased" by the jig.

Although jigs produce big fish, bait also brings good luck to the angler. When rigging for bait, attach a 10-to 20-ounce sinker to a 3-way swivel using line that is lighter than that on the reel; if the sinker snags the bottom, all of the rig except the sinker can be recovered. Eighteen inches of 80 -pound test monofilament with one or two $4 / 0$ or $5 / 0$ snelled Sproat hooks tied along its length should be attached to the second swivel leg. A commercial "Scotsman" or double-hook cod rig can be substituted for the homemade rig. Sand eels, mackerel, strips of herring and other fish, or crabs can be used as bait. However, a large piece of clam with its entrails trailing from the hook is the favored bait of many anglers. Clam hunks should be replaced when they turn pale.

In the early spring as water temperatures are beginning to rise, cod can be fished along the shoreline during early morning or from late evening until night. Typical gear includes a rod and reel with 15- to 20-pound test line rigged with a 2-ounce or larger pyramid sinker on a fish finder. Sea worms or clams on 3/0 hooks are used as bait.

Cod should be iced after capture to retain their delicate flavor; if they are iced in a large cooler, the melt water should be drained occasionally so the fish do not soak in warming water.

The white, flaky meat of cod has traditionally been Massachusetts' equivalent to "a chicken in every pot." This flavorful fish can be baked, broiled, boiled/poached, fried, made into cakes or chowder, or salted for long-term storage without loss of flavor or nutrition. The roe (eggs), tongues, and especially cheeks are considered delicacies by many. Poaching is nearly universally enjoyed as a method of cooking this species. To poach, add cod fillets or steaks and slices of lemon to rapidly boiling, lightly salted water. When the water resumes boiling, remove the pot from the stove and let it stand for 5 to 10 minutes until the meat flakes. Drain and cover with a sauce or add melted butter or margarine. For an excellent baked dish, stuff a cod with a "hot" breakfast sausage roll mixed with Italian-flavored bread crumbs or mashed potatoes. Bake at 350 degrees until the cod flakes.

Michael R. Ross and Laura A. Thorpe Department of Forestry and Wildlife Management University of Massachusetts
Robert C. Biagi

Cooperative Extension

University of Massachusetts

Supported by Federal Aid in Sport Fish Restoration Act, through the Massachusetts Division of Marine Fisheries, Department of Fisheries, Wildlife, and Environmental Law Enforcement, Executive Office of Environmental Affairs.

Produced by Cooperative Extension Communications Center. Liz Scott, design; Nancy Haver, Roy Lewando, illustration. University of Massachusetts, United States Department of Agriculture, and Massachusetts counties cooperating. Issued by E. Bruce MacDougall, Dean, in furtherance of the Acts of May 8 and fune 30, 1914. Cooperative Extension offers equal opportunity in programs and employment. When a product name is mentioned, no discrimination is implied against similar or equivalent products. CR60:12/87-10.M

This publication is part of the Marine Recreational Fisheries series, available from the Division of Marine Fisheries, 100 Cambridge Street, Boston, MA 02202. 


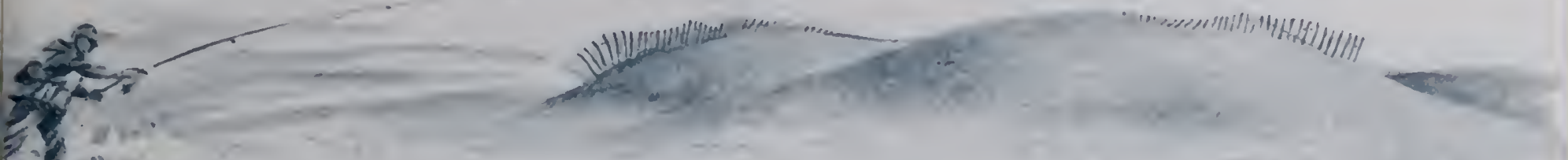

\section{Marine Recreational Fisheries of Massachusetts}

\section{Cunner}

$\mathrm{T}$ he cunner, a ubiquitous little species occurring all along the Massachusetts coastline, is native to the northwest Atlantic from Newfoundland to the Capes of New Jersey and occasionally to the Chesapeake Bay. It is most abundant within the Massachusetts Bay region.

The cunner is distinctive in appearance, differing markedly from most other species of fish caught by anglers in Massachusetts waters. This species has a small mouth containing several rows of jaw teeth which are arranged in a manner that gives the fish a "buck-toothed" appearance. The cunner has a single, long dorsal fin (A on diagram), the anterior three-quarters of which possesses a series of about 18 sharp spines. The pectoral fins (B), pelvic fins $(\mathrm{C})$, and tail are rounded in outline. The roof of the mouth and floor of the throat each contain a patch of knoblike teeth that are used for grinding food. The cunner is similar to the closelyrelated tautog, but differs from this species in having a slimmer body, a more pointed snout, and noticeably thinner lips.

The color of the cunner is as variable as the wide number of background colors found in the habitats in which it lives. For example, fish caught among red seaweeds tend to display reddish or rust-colored tones, those found on mud bottoms are often dark sepia, those on sandy substrates are pale brown speckled with black dots, and those taken from deep waters may be a rich red. Any of these colors may have a striking bluish iridescence or be mingled together in a mottled pattern.

Cunner may reach a maximum size of 3 pounds and 15 to 17 inches in length. However, most fish are 6 to 10 inches long and weigh less than one pound, and few individuals exceed 12 inches in length. One-year-old fish are generally 2 inches, 3 -year-olds 5 to 6 inches, and 6 -year-olds about 8 to 10 inches in length. Males and females become sexually mature by the age of 2 .

\section{Habits}

unner inhabit very shallow inshore waters from the tide mark downward in the northern part of their range, but tend to be found at depths of at least 15 to 20 feet south of New York. Cunner often move up into the larger salt creeks of estuaries. They generally remain within 5 or 6 miles of shore throughout their range, although occasional fish have been collected in the shallow areas of Georges Bank. Cunner do not form into schools; they are found on the bottom alone or in small groups, resting or swimming slowly among the eelgrass and rocks. 
Supported by Federal Aid in Sport Fish Restoration Act, through the Massachusetts Division of Marine Fisheries, Department of Fisheries, Wildlife, and Environmental Law Enforcement, Executive Office of Environmental Affairs.

Produced by Cooperative Extension Communications Center. Liz Scott, design; Nancy Haver, Roy Lewando, illustration. University of Massachusetts, United States Department of Agriculture, and Massachusetts counties cooperating. Issued by E. Bruce MacDougall, Dean, in furtherance of the Acts of May 8 and fune 30,1914. Cooperative Extension offers equal opportunity in programs and employment. When a product name is mentioned, no discrimination is implied against similar or equivalent products. CR60:12/87-10M

This publication is part of the Marine Recreational Fisheries series, available from the Division of Marine Fisheries, 100 Cambridge Street, Boston, MA 02202. 


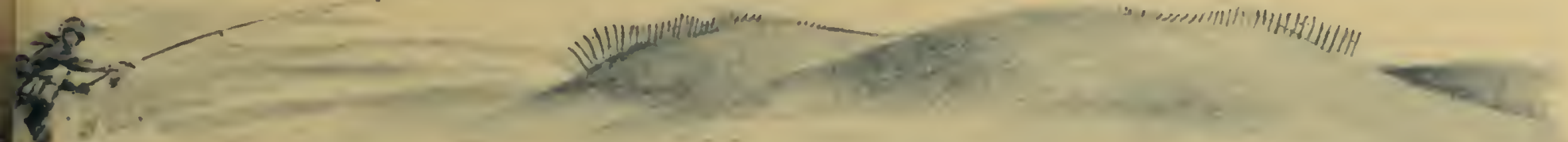

\section{Marine Recreational Fisheries of Massachusetts}

\section{S \\ ummer Flounder}

$\mathrm{T}$ he summer flounder, or "fluke," a flatfish noted for its fighting ability and flavor, is found in coastal waters from the southern Gulf of Maine to Florida. Important recreational and commercial fisheries for this species occur from Cape Cod to Cape Hatteras, North Carolina.

Like other species of flatfish, the fluke has both eyes on one side of its head and rests on the ocean floor on its side (refer to the bulletin on winter flounder in this series for a more detailed description of this adaptation). The fluke is called a left-handed flatfish because its eyes are on the upper surface of the head when the fish is facing left. This species has a very large mouth that extends below and beyond its eyes. The left-handed windowpane flounder differs from the summer flounder in having a much rounder body; in addition, the anterior rays in the dorsal fin (the dorsal fin of the fluke is marked A) of the windowpane are branched, forming a conspicuous fringe, and the posterior outline of the tail is rounded. The physically similar fourspot flounder differs from the fluke in having four large dark spots encircled by faint pinkish rings on its body.

Summer flounder are called the chameleons of the sea because of their ability to change color to match the bottom on which they are found. Generally they are white below and darker above, but they can turn various shades of gray, blue, green-orange, and almost black. The upper part of the fluke's body is marked with scattered spots that are darker than the general body color.

The angling record for summer flounder in Massachusetts is 21 pounds 8 ounces. Although the largest fluke may weigh up to 26 pounds, the average adult weighs 2 to 5 pounds and measures 17 to 25 inches long. A 15- to 16 -inch fish (which is only 2 to 3 years old) weighs about 1 to $11 / 4$ pounds, a 20 -inch fish about 3 to $3 \frac{1}{2}$ pounds, a 30 -inch fish 10 pounds, and a 37 -inch fish 20 pounds. Females may live up to 20 years and weigh more than 20 pounds, while males rarely exceed 7 years of age and 3 to 5 pounds in weight.

Both males and females become sexually mature at the age of 3. The fecundity (number of eggs produced in a single spawning season) of females increases with size and weight. A 14 -inch female produces about 460,000 , and a 27 -inch female about $4,200,000$, eggs in a season. 


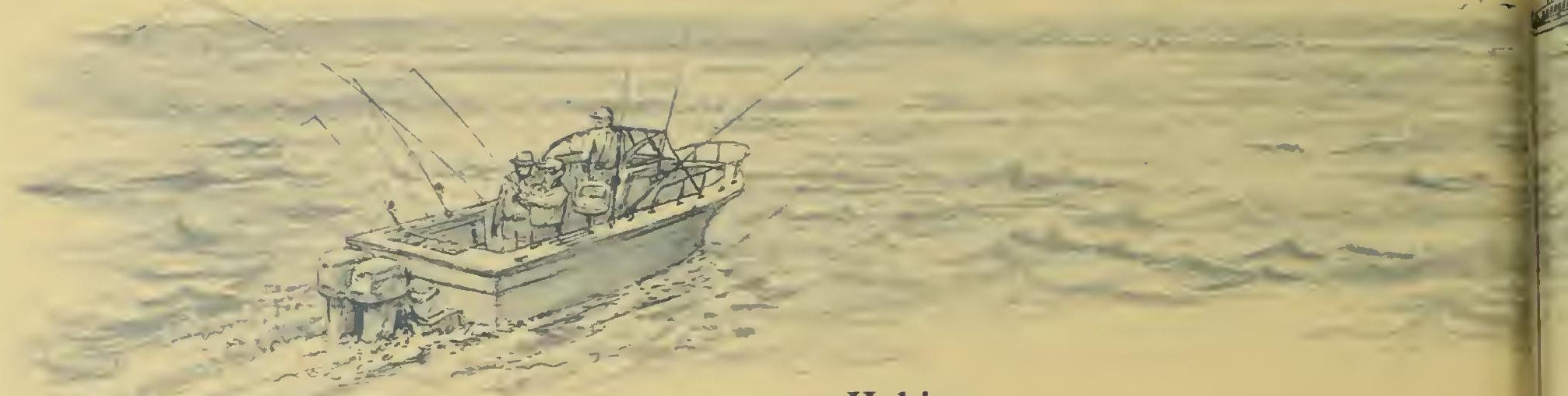

\section{Habits}

S

ummer flounder inhabit inshore areas of Massachusetts during the warmer periods of the year. Fluke prefer eelgrass beds and wharf pilings because of the protection they offer. When threatened, they quickly bury all but their beady eyes in the sand or escape at surprisingly high speeds. In the summer, small and medium-sized adults are found on the sandy and muddy bottoms of bays, harbors, and along the open coastline. Most of the larger fish tend to stay in somewhat deeper water ( 50 to 60 feet). With the approach of fall, summer flounder migrate to more offshore waters in depths from 150 to more than 500 feet.

Reproduction takes place in the fall, as soon as the fish begin migrating to wintering grounds. Peak spawning activity occurs from early September through early November in water temperatures of 53 to 66 degrees $F$ and at depths of 60 to 160 feet. The center of spawning activity occurs off the coasts of New York and New Jersey, with less concentrated activity occurring in southern New England waters.

The eggs float in the water column, hatching 72 to 75 hours after being laid. After hatching, the larvae are carried into bays and estuaries where they will spend the early portion of their lives. Autumn water-circulation patterns in southern New England tend to distribute surviving larval fish southward along the coast, resulting in the virtual absence of young summer flounder in Massachusetts waters.

The summer flounder, which depends upon sight to capture its food, feeds most actively during daylight hours. Juveniles feed upon small shrimp and other crustaceans, while adults eat a variety of fish, including small winter flounder, menhaden, sand lance, red hake, silversides, bluefish, weakfish, and mummichogs, as well as invertebrates such as blue crabs, squid, sand shrimp, opossum shrimp, and mollusks. Adults are very active predators, often chasing schools of small fish to the surface and leaping out of the water in pursuit of them. This behavior clearly distinguishes the summer flounder from the other more sluggish species of inshore flatfish.

\section{Status and Management}

$\mathrm{H}$ istorically, the summer flounder has been among the most important commercial and recreational flatfishes on the East Coast. The commercial catch in Massachusetts has been modest compared to catches along the mid-Atlantic states, but the population summering in Massachusetts coastal waters faces an intensive offshore otter trawl fishery in the winter and spring. Commercial catches in the southern part of the fluke's range were stable from the 1950 s to the early 1970s, while those in the northern portion of its range persistently declined over the same time period. In 1974 it was estimated that total commercial and recreational harvests exceeded a level that should be sustained for any extended period of time. Despite this caution, total harvest has exceeded the 1974 level in the 1980s.

Recreational fishing has always been a major component of the total fluke harvest, often 
exceeding commercial catches in the mid-Atlantic states. The recreational catch ranged from 26 to $60 \%$ of the total harvest from 1979 to 1984 on a coast-wide basis. Certain regions have historically supported tremendous recreational fishing. One such region, the Great South Bay of Long Island, reported as many as $2,000,000$ fluke landed yearly during the late 1950 s and early 1960 s. The total coastal recreational catch from 1979 to 1984 ranged from 5,000,000,000 to $18,900,000,000$ fish.

Although population levels in the 1980 s have been somewhat higher than they were in the 1960s and 1970s, persistently high harvest levels may once more reduce this species' abundance. The Atlantic States Marine Fisheries Commission developed a Summer Flounder Management Plan that was adopted by coastal states from Massachusetts to North Carolina in 1982. This plan established a minimum legal size limit of 14 inches to protect this important coastal fishery resource.

\section{Angling and Handling Tips}

$\mathrm{F}$ luke are well-known for the aggressive way they grab bait and battle when hooked. They offer a particular challenge to the angler bold enough to use light tackle. Average-sized fluke, sometimes called "flatties," weigh about 2 to 4 pounds, while the aptly named "doormats" (so-called due to their similarity in size to a welcome mat) weigh 8 or more pounds and provide memorable battles for the angler lucky enough to hook them.

Summer flounder start to move inshore in July and provide action until waters begin cooling near the end of September. They can be found on sandy or muddy bottoms in many inshore habitats and are particularly abundant in fast-moving rips that gather debris and bait fish.

Anglers troll, chum, still-fish, and cast for fluke, but the most popular method is drifting the bait along the bottom. When drifting, the bail of the reel should be open and the line held by the finger. Once the line stops drifting and is tugged, it should run free for a moment to let the fish get the bait

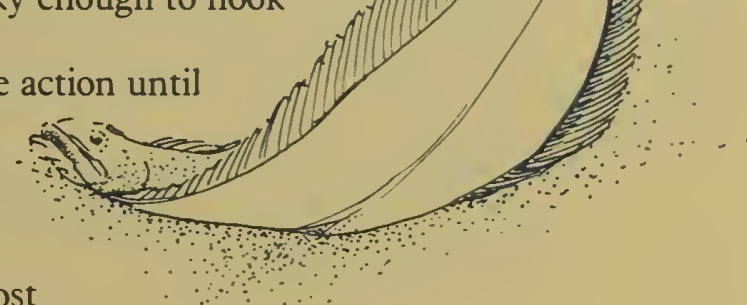




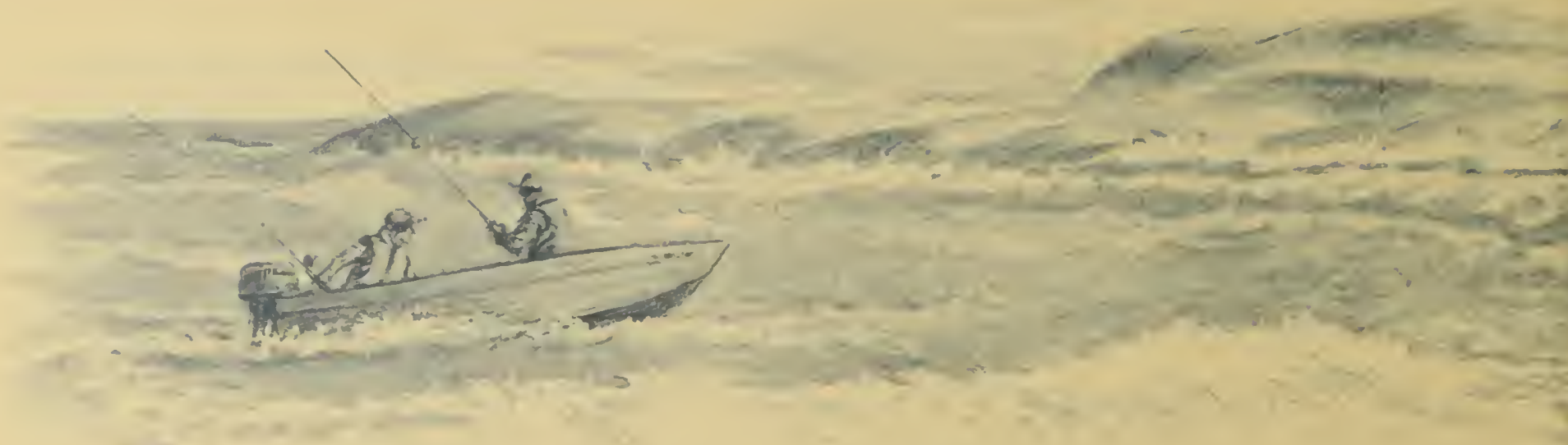

in its mouth before the hook is set. Casting a baited red and white bucktail rig from boat or shore can also be a rewarding approach. The jig should be retrieved with a slow, pumping action. When a fluke grabs the rig, the rod tip should be lowered to slacken the line; when the line tightens again, the hook can be set.

Shoreline anglers use medium-weight spinning gear spooled with 12-pound test line, while boat anglers fishing deeper water with strong currents need 15- to 20-pound test line on light to medium conventional gear to match the larger fish found there. Commercial rigs with spinners are used by many anglers. One favorite is a $3 / 8$ to $1 \frac{1}{2}$ ounce weighted bucktail that can be baited with strips of fresh or frozen squid or bait fish such as sand lance. If these baits aren't available, 4- to 5 -inch strips of meat cut from the tails of fish such as sea robins can be used. Some anglers prefer strips of meat from the belly area of a fluke or bluefish, or half of a snapper bluefish.

A few anglers prefer homemade rigs made by tying a l- to 2-ounce sinker to the end of the line and a "dropper loop" or three-way swivel 4 inches above the sinker. A 3-foot leader with a 1/0 to $3 / 0$ hook is attached to the loop or swivel. A 4- to 5-inch strip of squid split along half its length is attached to the hook along with a baitfish hooked through the lips. This rig is bounced along the bottom as the angler drifts or casts.

The white, flaky meat of the summer flounder is highly rated due to its delicate flavor and texture. This versatile fish provides delightful dining when steamed, poached, baked, broiled, sautéed, fried, or microwaved. Large "door mats" can be quarter-filleted for most recipes or cut into steaks and grilled over charcoal or gas.

Michael R. Ross and Laura A. Thorpe

Department of Forestry and Wildlife Management

University of Massachusetts

Robert C. Biagi

Cooperative Extension

University of Massachusetts

Supported by Federal Aid in Sport Fish Restoration Act, through the Massachusetts Division of Marine Fisheries, Department of Fisheries, W'ildlife, and Environmental Law Enforcement, Executive Office of Environmental Affairs.

Produced by Cooperative Extension Communications Center. Liz Scont, design; Nancy Haver, Roy Lewando, illustration. University of Massachusetts, United States Department of Agriculture, and Massachuselts counties cooperating. Issued by E. Bruce MacDougall, Dean, in furtherance of the Acts of May 8 and June 30, 1914. Cooperative Extension offers equal opportunity in programs and employment. When a product name is mentioned, no discrimination is implied agatnst similar or equivalent products. CR60:12/87-10:11

This publication is part of the Marine Recreational Fisheries series, available from the Division of Marine Fisheries, 100 Cambridge Street, Boston, MA 02202. 
S. UML1.2:M34 Flounle Wintir

University of Massachusetys Cooperative Extension - Massachusetts Division of Marine Fisheries

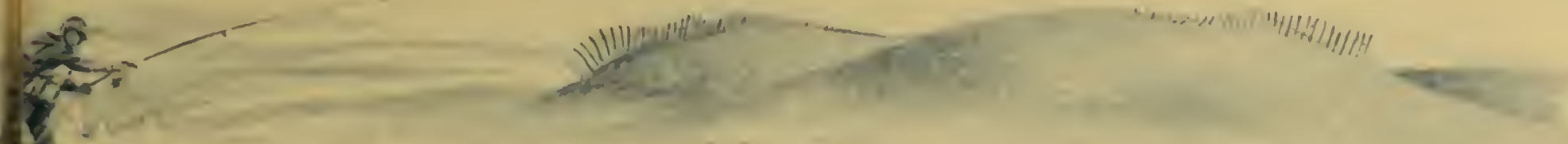

Marine Recreational Fisheries of Massachusetts

Winter Flounder

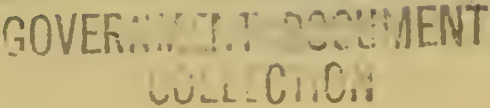

$\mathrm{T}$ he winter flounder, one of the most common and popular recreational species in New England, is highly favored because of its fine flavor and thick fillets. It ranges from southern Labrador to the waters of South Carolina and Georgia and is most abundant from the Gulf of St. Lawrence to the Chesapeake Bay. This species' name derives from its tendency to mbrejersity of Massachusett during the winter months to shallower inshore waters, where it is easily caught. It is frequently called a "blackback" when it is smaller than 3 pounds and a "lemon sole" when it is larger.

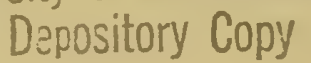

Like all flatfish, the winter flounder has both eyes on one side of the head. A newly hatched flatfish larva has one eye on each side of its head, but within months it adapts to a bottom-dwelling lifestyle, by which time one eye has moved to the other side of the head. Unlike most other bottom-dwelling fish that rest by lying on their bellies, a

flatfish rests and swims on its side. Having both eyes on one side of its head enables the flatfish to rest on the ocean's floor while directing both eyes upward.

The winter flounder is referred to as a right-handed flounder because the eyes are located on its upper surface when the fish is pointing to the right. This species is oval in shape, with a body that is about two times as long as it is wide. Its small mouth does not extend backward to below the eye. The lateral line (A on diagram above), a series of pores used to detect local turbulence in the water, runs in a nearly

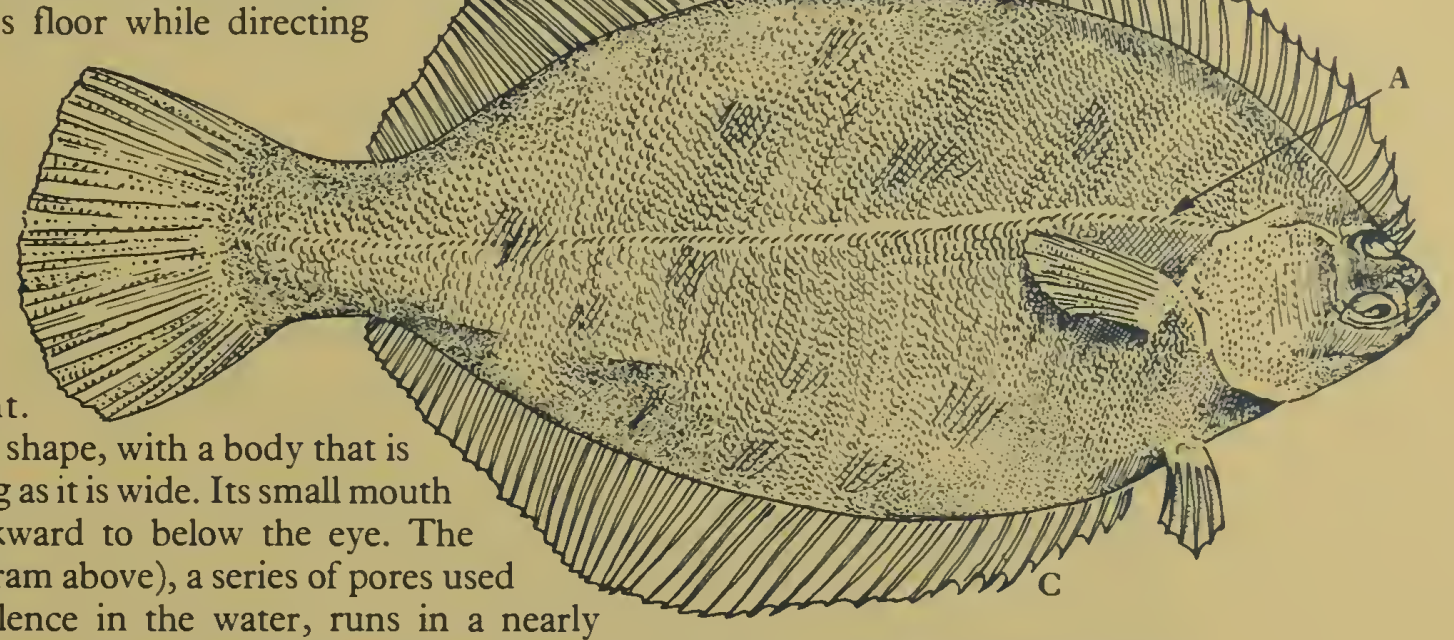
straight line from the head to the base of the tail. The dorsal fin ( $\mathrm{B}$ above) originates opposite the forward edges of the eyes and follows the length of the body at a uniform height. The anal fin (C above) also extends the length of the body, but is noticeably highest near its midpoint.

\begin{tabular}{|c|c|c|}
\hline Age & $\begin{array}{l}\text { South of Cape Cod } \\
\text { length in inches } \\
\text { male female }\end{array}$ & $\begin{array}{l}\text { Georges Bank } \\
\text { length in inches } \\
\text { male female }\end{array}$ \\
\hline 2 & $\begin{array}{ll}7.5 & 8.5\end{array}$ & $10.0 \quad 8.5$ \\
\hline 4 & 13.8 & 18.5 \\
\hline 6 & 16.5 & 22.0 \\
\hline 10 & 18.5 & 24.1 \\
\hline
\end{tabular}

The color of this species is highly variable, since the winter flounder can change color to mimic the bottom on which it rests. However, the scaled upper side of the body of most individuals ranges from a muddy or reddish brown to black, and the scaleless underside is white. Smaller fish are generally paler and have a less uniform color pattern than larger, older fish.

The largest recorded winter flounder caught by a commercial boat weighed 8 pounds and was 25 inches long. This fish was taken on Georges Bank, where many of the larger winter flounder are 


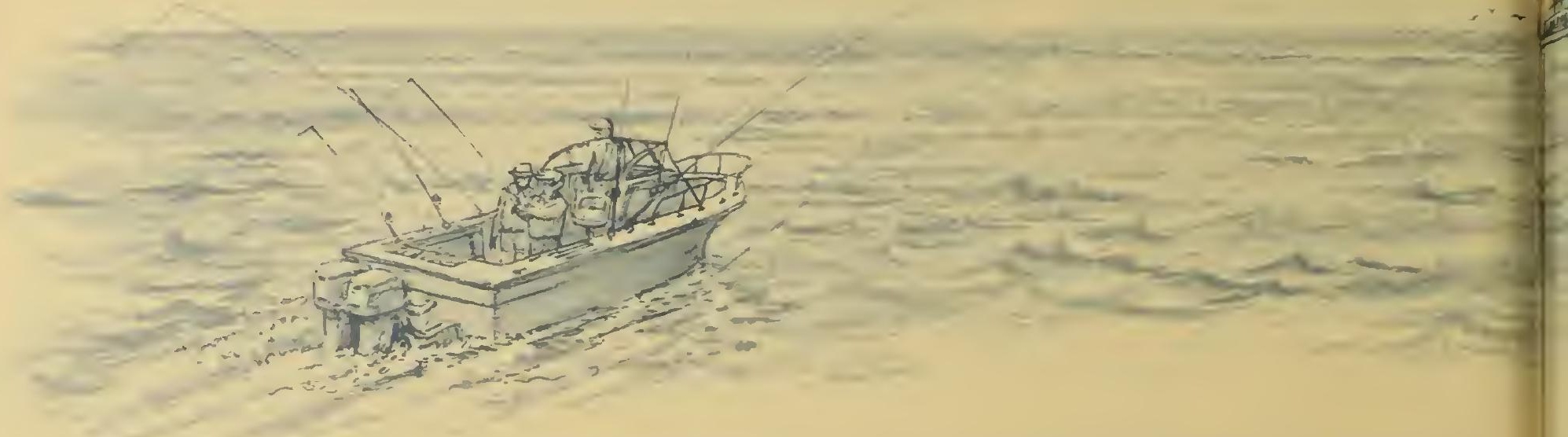

caught. The Massachusetts angling record, set by a fish caught in Massachusetts Bay in 1982, stands at 6 pounds. Female winter flounder grow faster than males and attain larger maximum sizes. The table on the preceding page lists average lengths at selected ages for winter flounder from two geographic regions.

Both male and female winter flounder normally reach sexual maturity at 3 years of age. The fecundity (number of eggs produced in a year) increases with body size, with smaller females producing about 500,000, and larger females around 1,500,000 eggs per year.

\section{Habits}

W inter flounder are caught in almost any shallow bay or estuary where the bottom is sandy or silty. They frequently move into the brackish water of river mouths and also range into the deeper waters of the Nantucket Shoals region and the shallower areas of Georges Bank. When they are on soft bottoms, they lie buried in the mud, dashing out occasionally to feed on invertebrates moving close by.

This is one of the most stationary of fishes, displaying a very limited seasonal migration. Fish overwinter in inshore areas. As summer approaches, the shallow inland waters become warm, and the larger fish move offshore to deeper water. Juveniles will remain in estuaries for up to 3 years, moving offshore as they grow older. Although a given population usually remains fairly stationary, there is evidence of wide-scale movement of some individuals, perhaps in search of food.

In New England, reproduction occurs in estuaries from January to May, with peak activity during February and March when water temperatures are the coldest of the year, ranging from 32 to 39 degrees F. Evidence suggests that specific individuals return for many years to the same site to spawn.

Unlike the floating eggs of all other local flatfish, eggs of the winter flounder clump together in masses on the bottom. Eggs, usually laid on clean sand, hatch 15 to 18 days after being released. By the time the larvae are $1 / 3$ inch long, they have undergone complete metamorphosis, the left eye having migrated to the right side of the body. Mortality is highest during larval stages, partly due to predators such as striped killifish and jellyfish.

Larval and juvenile winter flounder feed on the egg, larval, and adult stages of various invertebrates. Adults feed on a great variety of organisms including shrimp, clams, polychaete worms, fish fry, and bits of seaweed. Winter flounder will bite almost any bait, provided the hook is small enough. They feed mainly during daylight hours and are more active during flooding or ebbing tides than during slack water periods. 


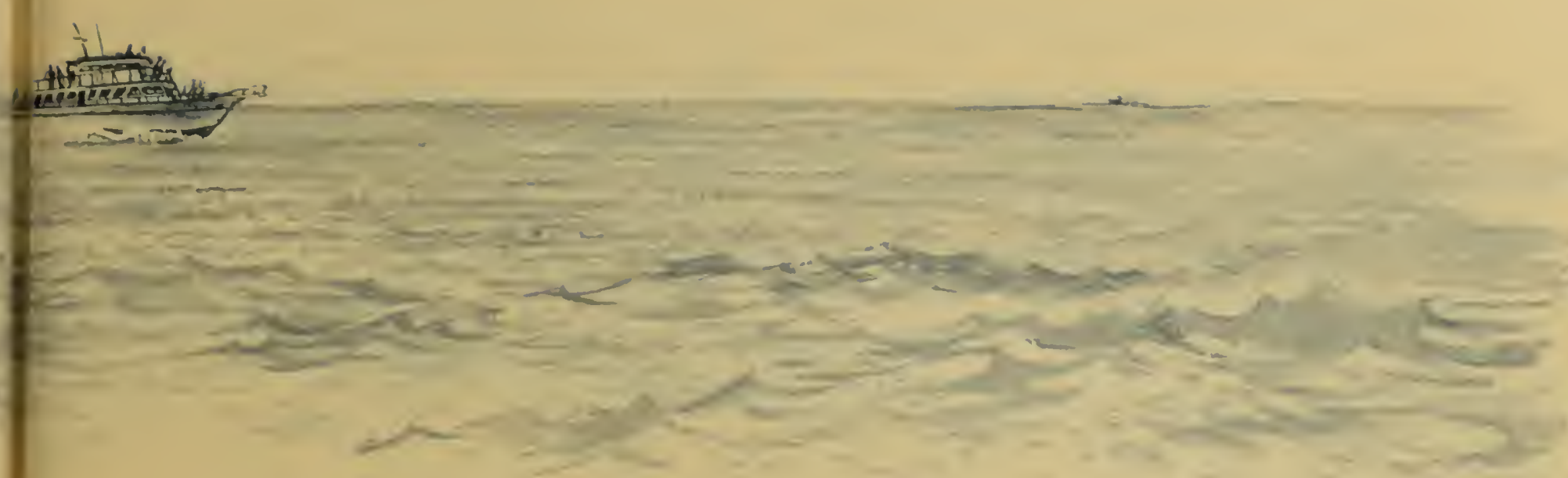

\section{Management}

$\mathrm{E}$ ach year anglers catch more winter flounder than any other species of fish in New England coastal waters. Presently only the bluefish attracts a greater number of anglers. Recreational angling is a major component of the total annual harvest of this species, accounting for $30 \%$ to $46 \%$ of the yearly poundage harvested between 1979 and 1985 .

Although winter flounder populations historically showed less tendency to fluctuate in abundance than did some other New England groundfish species, harvest levels had dropped by the mid-1930s. Improved fishing technology and the introduction of foreign distant-water fishing fleets into the New England region increased fishing pressure throughout the 1950s and 1960s. In 1976, the U.S. 200 -mile fishery management zone was established, markedly limiting fishing by foreign vessels within this protected area. However, since winter flounder fisheries include an important inshore component that was not exploited by foreign vessels, the establishment of the 200-mile fishery management zone in 1976 did not markedly reduce total harvests. Winter flounder fisheries were most heavily exploited in the late 1970s and early 1980s. Catches have declined almost yearly since 1981. It is now believed that this species is being harvested at levels that cannot be sustained in the future.

Commercial harvests are regulated under the Northeast Multispecies Fishery Management Plan of the New England Fishery Management Council. The plan includes minimum legal size limits and area closures to protect juvenile fish. The Massachusetts Division of Marine Fisheries has established regulations for inshore populations that include a minimum legal size limit for fish (12 inches in 1987) and a February 1 to April 30 closure of all waters within 1 mile of the shoreline.

This closure suspends all commercial harvests, and restricts recreational fishing to one line and two hooks per angler. Both of these regulations are meant to protect the reproductive potential of this species by preventing harvest until the fish reach an age where they have reproduced at least once, and by allowing

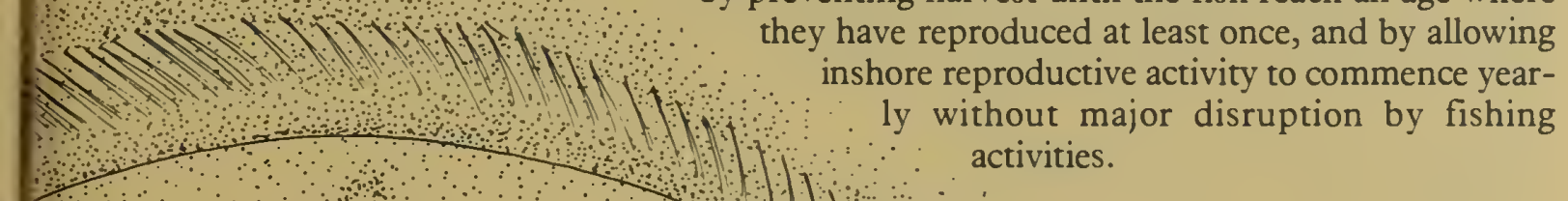




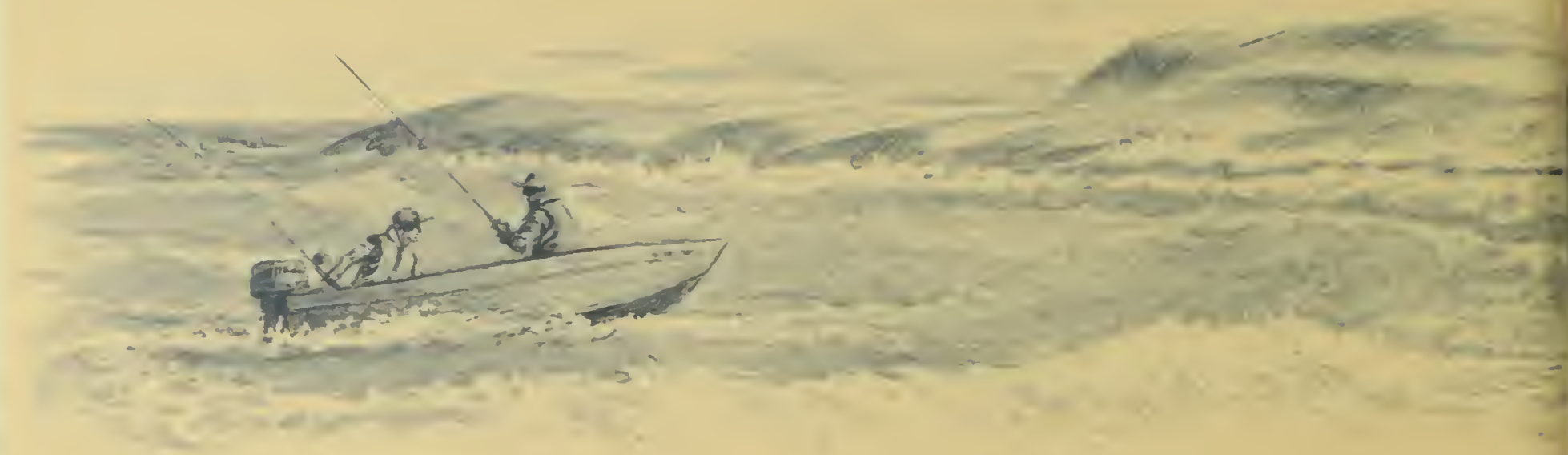

\section{Angling and Handling Tips}

I

nshore blackback fishing usually begins in early spring and lasts until the end of May, when flounder move farther offshore. When blackbacks return to inshore areas in September, anglers fish for them until the weather becomes too unpleasant in late fall. Anglers pursue this species from docks, jetties, and party and private boats in nearly all Massachusetts bays and estuary mouths. Areas characterized by sandy mud substrates and patches of eelgrass provide anglers with the greatest opportunity for success.

Winter flounder provide the most enjoyable action when caught on light tackle. Most anglers use 10 - to 15 -pound test line on a $61 / 2$ foot medium-action spinning rod or a small boat rod. Heavier equipment is needed when tidal currents require sinkers of more than 1 or 2 ounces to hold bait to the bottom-a must when fishing for this bottom fish. Flounder hooks with attached snells or leaders can be fastened to the end of a wire spreader with a sinker attached to its center, or tied directly to the line 12 to 18 inches below a sinker. Many anglers believe that attaching yellow beads above the hook or using yellow sinkers will attract greater numbers of blackbacks.

Many anglers recommend chumming. Ground or crushed clams or mussels in a mesh bag or "chum pot" are frequently used, while handfuls of corn from a freshly opened can are also favored. Sandworms are considered the best bait for winter flounder, but bloodworms and clams also are commonly used. Some anglers prefer strips of squid and even night crawlers. The key is to use very little bait; an inch of worm will work best. Blackbacks can quickly and quietly sneak in and take bait; thus, unattended rods lose fish. The rod should be raised often to check for fish as well as to attract them.

No fish lends itself to more imaginative dishes than does the winter flounder. Its texture and delicate flavor are well-suited to sauces, spices, fruits, vegetables, and other seafoods. Few species can be mixed with so many things and still stand out. Winter flounder can be fried, steamed, baked, microwaved, or broiled, and can be substituted for other species in most fish recipes.

Michael R. Ross and Laura A. Thorpe

Department of Forestry and Wildlife Management

University of Massachusetts

Robert C. Biagi

Cooperative Extension

University of Massachusetts

Supported by Federal Aid in Sport Fish Restoration Act, through she Massachusetts Division of Marine Fisheries, Department of Fisheries, Wildlife, and Environmental Law Enforcement, Executive Office of Environmental Affairs.

Produced by Cooperative Extension Communications Center. Liz Scotl, design; Nancy Haver, Roy Lewando, illustration. University of Massachusetts, United States Department of Agriculture, and Massachusetrs counties cooperaring. Issued by E. Bruce MacDougall, Dean, in furtherance of the Acts of May 8 and fune 30, 1914. Cooperative Extension offers equal opportunity in programs and employment. When a product name is mentioned, no discrimination is implied against similar or equivalent products. CR60:12/87-10.11

This publication is part of the Marine Recreational Fisheries series, available from the Dizision of Marine Fisheries, 100 Cambrige Street, Boston, MA 02202. 
UM4:2:MBe Had.

University of Massachusetts Cooperative Extension - Massachusetts Division of Marine Fisheries

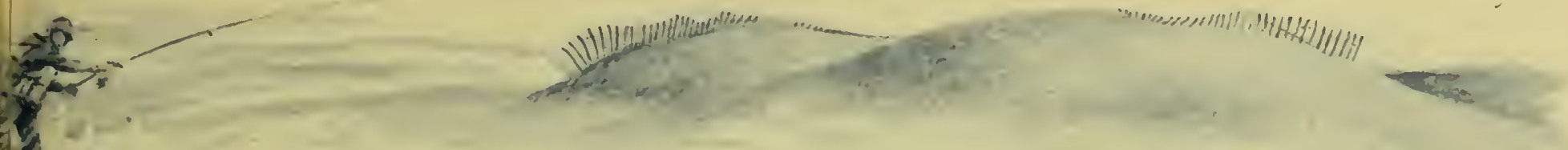

\section{Marine Recreational Fisheries of Massachusetts}

\section{Haddock}

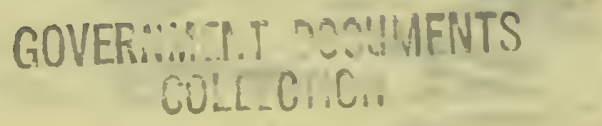

$\mathrm{T}$

he haddock, a member of the cod family renowned as splendid table fare, inhabits both the

American and European coasts of the Atlantic Ocean. In the northwest Atlantic, it ranges from the southern end of the Grand Banks to Cape Cod in the summer, and it extends its range southward to Cape Hatteras, North Carolina, in the winter.

Haddock, like the closely related cod, pollock, and tomcod, are easily distinguished from other coastal Massachusetts fish by their three dorsal and two anal fins (A and B, respectively, on diagram below). The front dorsal fin is triangular in shape and taller than the following two. The posterior two are squarish, the middle dorsal being slightly larger than the last. Of the two anal fins, the second or posterior one is a mirror image of the third dorsal fin. Haddock can be distinguished from the other closely related members of the cod family by a black lateral line (C on diagram; the lateral line is a series of sensory pores that detect local disturbances in the water) and a large spot on each side of the body over the pectoral fins (pectoral fin marked D).

The top of the head, the back, and the upper sides are a dark purplish-grey. The lower sides are shiny grey tinged with pink, and the belly and lower head are white. The haddock has dark dorsal fins, pectoral fins, and tail; the anal fins are pale and spotted with black at the base.

The largest recorded haddock, which was landed by a commercial vessel, weighed 37 pounds and measured 44 inches in length. The Massachusetts angling record for haddock is 20 pounds, set by one fish caught on Stellwagen Bank in 1972 and one at Boston Lightship in 1974. One-year-old fish may reach 6 inches, two-year-olds 12 inches, and three-year-olds about 17 inches in length. Few haddock exceed 20 to 24 inches in length, 3 to 5 pounds in weight, and 9 to 10 years of age.

Both males and females are sexually mature by the time they are 2 or 3 years old. The fecundity (number of eggs produced in a year) of females is related to their body size. Females weighing 2.2 pounds produce about 170,000 eggs, while the largest females may release as many as $3,000,000$ eggs in one spawning season.

\section{Habits}

$\mathrm{H}$ addock inhabit deep, cool waters, rarely entering estuaries or river mouths. They are primarily found at depths of 140 to 450 feet and generally avoid depths of less than 30 . Haddock prefer substrates of gravel, smooth rock, or sand littered with shells, and water temperatures of 35 to 50 degrees $\mathrm{F}$. They migrate seasonally to areas that provide optimal habitat 


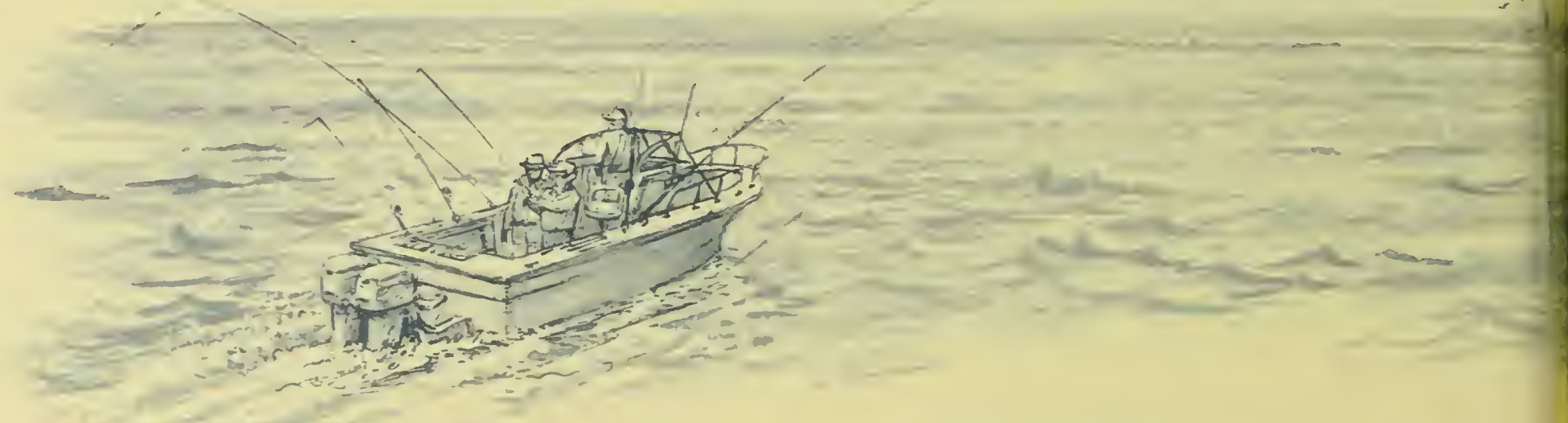

conditions. In winter, haddock move to deep water where the temperature is warmer and more constant than that in shallower areas. Most overwinter offshore from southern New Jersey to Cape Hatteras. By early spring they seek more northerly areas in New England, moving into shallower waters of the Gulf of Maine and Georges Bank, where they remain all summer.

The haddock off Massachusetts reproduce on sandy, rocky, or muddy bottoms from January to June, showing the greatest activity in March and April. Spawning occurs offshore at depths of 100 to 600 feet and in temperatures of 35 to 45 degrees F. Georges Bank is the most productive spawning area for haddock in the northwest Atlantic.

The buoyant eggs drift in the water, hatching in approximately 15 days. Young haddock will float near the surface for up to 3 months after hatching, drifting with the prevailing currents. Subsequently they will move to the ocean floor, which they inhabit for the rest of their lives.

Haddock suffer extremely high death rates during early life stages. Many die from starvation or predation by species such as cod and pollock. However, the number of larvae that survive in a given year is often chiefly determined by their location when they are ready to become bottom dwellers. If the currents in which they have been suspended have carried them far offshore from the continental shelf, few larvae will survive. Thus, the number of fishes surviving early life stages is highly variable and unpredictable from year to year. Haddock populations characteristically suffer through extended series of years when few fish survive early life stages. Recreational and commercial harvests have a great effect upon this species since individuals removed from the population by fishing are not necessarily replaced by reproduction.

Before descending to the ocean floor, larval haddock feed upon microscopic copepods. Bottom-dwelling juveniles and adults feed upon almost any slow-moving invertebrate including small crabs, sea worms, clams, starfish, sea cucumbers, sea urchins, and occasionally squid. Herring, sand lance, small eels, or other young fish only rarely occur in their diet.

\section{Management}

$\mathrm{H}$ istorically, the haddock was abundant throughout the open waters of the Gulf of Maine and on all offshore banks, especially Georges Bank. The Georges Bank-South Channel area was one of the most productive haddock grounds in the world. This species also occurred in many areas of the coastal belt within 15 to 20 miles of land.

In the 20 th century, however, the haddock has displayed wide fluctuations in abundance. The commercial fishing industry, boosted by new markets for fresh fish and frozen fillets; harvested over $220,000,000$ pounds of haddock in 1929. Annual harvests from 1930 to 1947 dropped to $25 \%$ to $67 \%$ of that in 1929 . Concern over this reduction in harvest was a major impetus in establishing the International Commission of Northwest Atlantic Fisheries (ICNAF), a multi-national attempt at managing fisheries resources. In the mid-1950s, foreign countries established distant- 


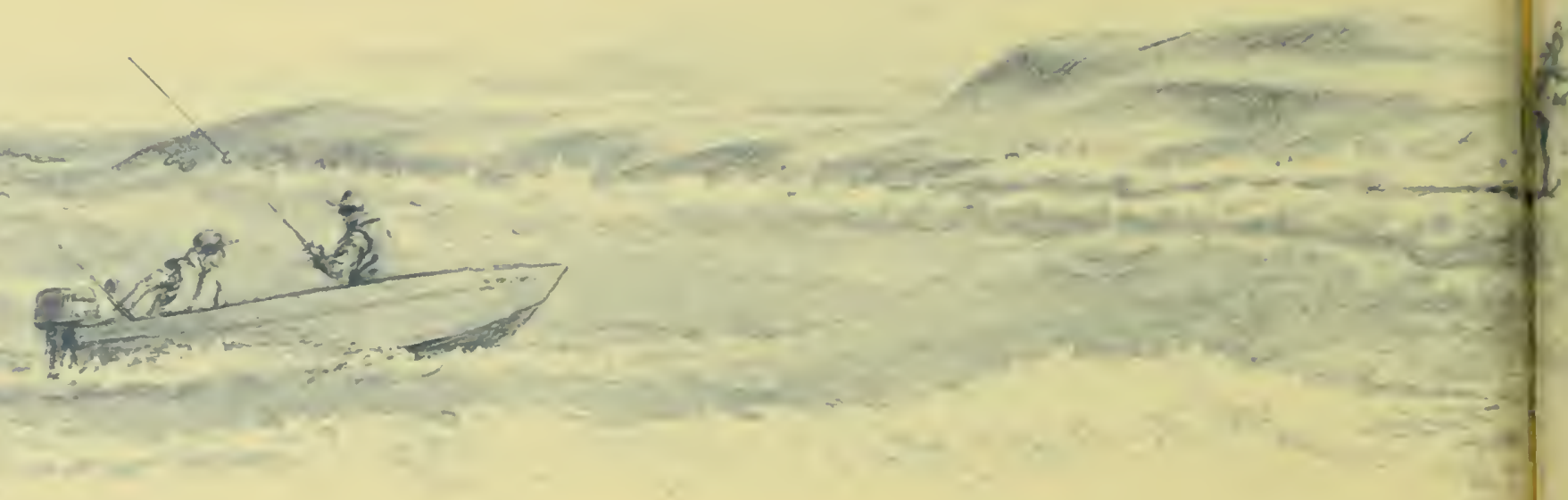

\section{Angling and Handling Tips}

$\mathrm{F}$

ew fish are more delicately flavored or more finely fleshed than the haddock. Traditionally, haddock fillets are marketed with their distinctively colored skin intact as a sign to consumers that the high price they are paying is indeed purchasing this highly valued fish.

Haddock are caught from spring to fall, with fishing activity generally greatest in August and September. Anglers pursue this deep-water species from private, charter, or party boats.

A medium-action 8-foot boat rod with a fast-tapering tip is preferred by many anglers. A sensitive rod is necessary to feel the light bumps the haddock creates when it grabs a baited hook. Forty-pound test monofilament line on a high-speed conventional reel is usually recommended. Heavy line is necessary even though the haddock is a modest-sized species because anglers fishing in deep waters cannot predict what other larger fish might grab the bait. Old-timers often favor braided line, feeling that it does not have as much stretch as monofilament and more easily hooks a fish in deeper waters.

A typical haddock rig consists of the following. A swivel (to prevent twisting) is tied to one end of a 4-foot piece of 50-pound test leader. A bank sinker is looped to the other end of the leader. Number $6 / 0$ or smaller hooks, with a short piece of yellow surge wound over their shanks, are attached to the leader by two 6 to 10 inch long "droppers," or loops. Ten to 20 ounces of sinker are needed to hold the rig on the bottom, depending upon currents and depths. Fresh clams or squid are very successful baits.

After the baited rig is lowered to the bottom, all slack should be retrieved. Unlike the cod, which gives a sharp yank, haddock bite in a series of light bumps. These slight taps can best be felt if the line is held between a thumb and finger. Because haddock have soft mouths, they are easily lost if not properly played after being hooked. When a haddock taps the bait, the hook should be set with a steady pull rather than a jerk, and the fish should be steadily retrieved without pumping the rod.

The meat of haddock is lean and white. It is less firm than cod and flakes beautifully when cooked. Haddock is excellent baked, broiled, poached, microwaved, or used in chowders and stews. Traditionally, New Englanders fry haddock fillets or bake them whole with a bread crumb and spice stuffing. For a change of pace, try the following simple New England style of poaching. Rub the inside of a dressed haddock with salt, wrap it in cheesecloth, and cook it in boiling water or bouillon for 25 or 30 minutes, or until it flakes. Remove it to a platter, garnish, surround with alternating boiled potatoes and cooked beets, and serve with mushroom soup as a sauce.

Michael R. Ross and Laura A. Thorpe

Department of Forestry and Wildlife Management

University of Massachusetts
Robert C. Biagi

Cooperative Extension

University of Massachusetts

Supported by Federal Aid in Sport Fish Restoration Act, through the Massachusetts Division of Marine Fisheries, Department of Fisheries, Wildlife, and Environmental Law Enforcement, Executive Office of Environmental Affairs.

Produced by Cooperative Extension Communications Center. Liz Scott, design; Nancy Haver, Roy Lewando, illustration. University of Massachusetts, United States Department of Agriculture, and Massachusetts counties cooperating. Issued by E. Bruce MacDougall, Dean, in furtherance of the Acts of May 8 and fune 30, 1914. Cooperative Extension offers equal opportunity in programs and employment. When a product name is mentioned, no discrimination is implied against similar or equivalent products. CR60:12/87-10.M 


\section{$\because 5.0 M 4.2: M 34 / H a l$.}

University of Massachusett\$Cooperative Extension - Massachusetts Division of Marine Fisheries

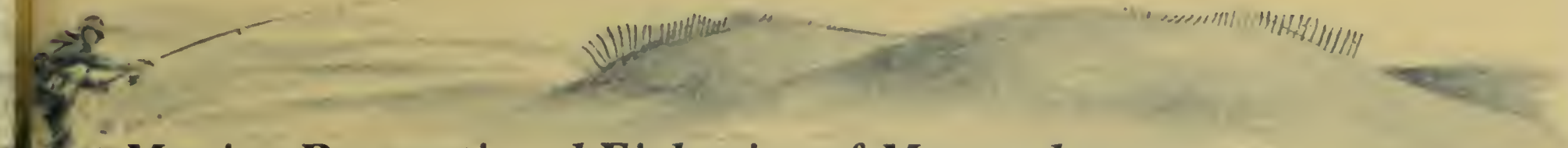

\section{Marine Recreational Fisheries of Massachusetts}

\section{Halibut}

he Atlantic halibut, a giant amongst the flatfish, is native to both sides of the Atlantic

Ocean. In the western Atlantic it ranges from the coast of Greenland to New Jersey. It is

most abundant from Nantucket Shoals to the northern Gulf of St. Lawrence, the southern portion

of the Grand Bank, and the deep waters of the outer continental shelf off Labrador.

Like other flatfish, halibut have both eyes on one side of the head. When they are newly hatched larvae, these fish have one eye on each side of the head; as they grow, one eye migrates, and the body becomes markedly flattened. In the halibut, this metamorphosis is completed when the fish is less than $1 \frac{1}{2}$ inches long. The halibut is called a right-handed species because both eyes occur on the right side of the body. When resting on the ocean floor, it lies on its "blind" left side. Other flattened bottom dwellers such as skates and rays rest on their broadly expanded bellies; such fish do not possess the specialization of eye position displayed by the flatfish.

The halibut differs markedly from other right-handed flatfish in the northwest Atlantic. Its body is less broadly flattened and thicker. It has a large mouth that extends posteriorally to below the eyes and contains sharp, curved teeth. The dorsal and anal fins ( $\mathrm{A}$ and $\mathrm{B}$ respectively on dia-

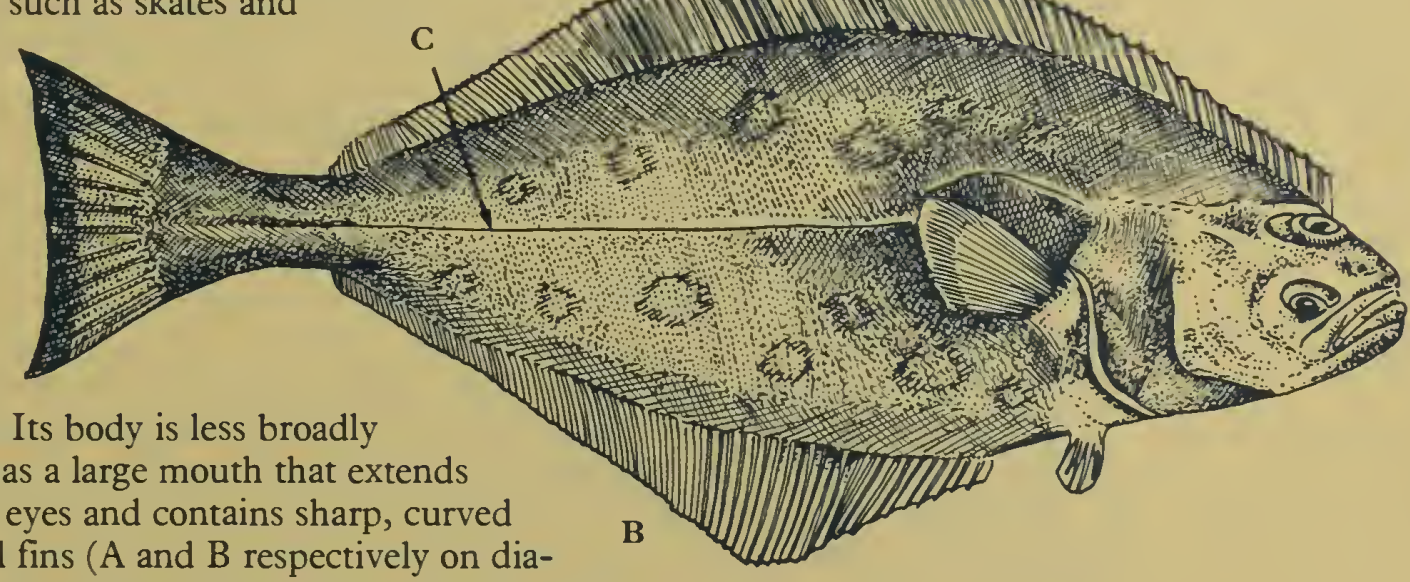
gram) are decidedly highest at their middle. The posterior edge of the tail is concave, and the lateral line (a series of sensory pores that detect vibrations in the water) is noticeably arched at its anterior end ( $\mathrm{C}$ on diagram).

Halibut range in color from olive-brown to chocolate or almost black on the upper side. Younger fish are usually paler and blotched. The blind or lower side is pure white in smaller fish or mottled with gray in larger fish.

Halibut are the largest of all flatfish. The largest northwestern Atlantic halibut on record weighed about 700 pounds. However, fish exceeding 300 pounds were considered rarities even before this species was depleted due to fishing pressure. The angling record for Massachusetts waters weighed 250 pounds. Most "large" halibut commercially landed weigh from 50 to 200 pounds.

Females are somewhat longer and heavier than males of the same age. Halibut grow very slowly. Five-year-old fish average about 22 inches in length, and weigh 3 to 4 pounds; 10 -year-olds range from about 30 to 55 inches in length and weigh from 12 to 60 pounds. It has been estimated that the immense fish weighing 400 or more pounds may be as much as half a century old. 


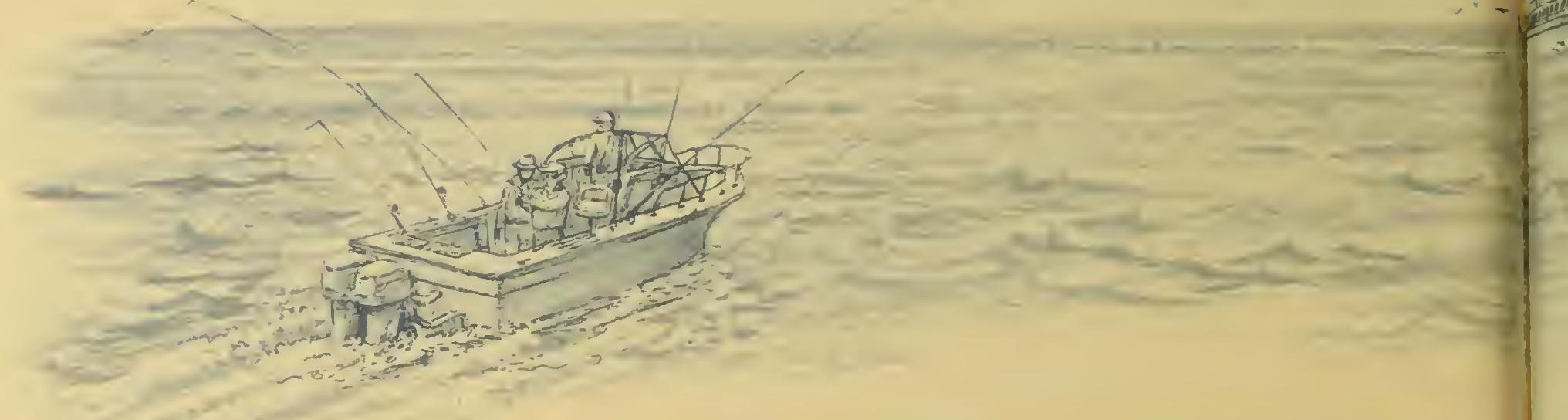

Females become sexually mature at about 9 or 10 years of age, while males do so somewhat earlier. The fecundity (number of eggs produced in a given spawning season) of females increases with size and weight. A female Atlantic halibut of about 200 pounds produces as many as $2,180,000$ eggs in a season.

\section{Habits}

$\mathrm{H}$ alibut are found in subarctic waters; they prefer temperatures from 36 to 47 degrees $F$ and depths from 200 to 3,000 feet. As young fish, they inhabit shallower areas, but move into progressively deeper waters as they grow. Thus, the largest, oldest specimens tend to occur in the deeper waters inhabited by this species. Although they are bottom dwellers, individuals are occasionally sighted feeding at the surface. They live on sand, gravel, or clay bottoms, tending to avoid mud and rock substrates.

Halibut display seasonal movement patterns associated with changes in water temperature. In the southern portion of their range, they tend to be found in shallow areas such as Georges Bank and Nantucket Shoals only in the winter and spring; as water temperatures rise in the summer to the upper $40 \mathrm{~s} \mathrm{~F}$, these fish withdraw to deeper waters. In the northern portion of their range, halibut tend to move to deeper waters with more stable water temperatures in the fall as shallower areas cool to the low 30 s F.

Halibut reproduce from December to February. In the northwestern Atlantic, peak spawning activity occurs in January. Halibut reproduce on the ocean bottom at depths of from 900 to over 2,000 feet, and are believed to congregate at particular spawning sites every year.

Although laid on the bottom, the eggs subsequently are suspended in the water column at depths of 180 to 300 feet, and at temperatures between 37 and 39 degrees F. After hatching, larval halibut remain suspended in the water column, feeding upon plankton and drifting in currents. During this time, halibut tend to rise slowly in the water column and drift toward more inshore areas. Thus, by the time they metamorphose, young halibut settle to the substrate as bottom dwellers in waters much shallower than those they may occupy later in life.

Halibut feed mainly on groundfish, but occasionally eat a variety of shellfish. Their diet includes whatever species happen to be most abundant at a particular time, including cod, cusk, haddock, sculpins, silver hake, herring, sand lance, flounders, crabs, lobsters, shrimps, clams, and mussels. Seabirds have even been found in the occasional specimen. In turn, adult halibut are eaten by seals and Greenland sharks. They serve as a major dietary item for the latter, when available. 


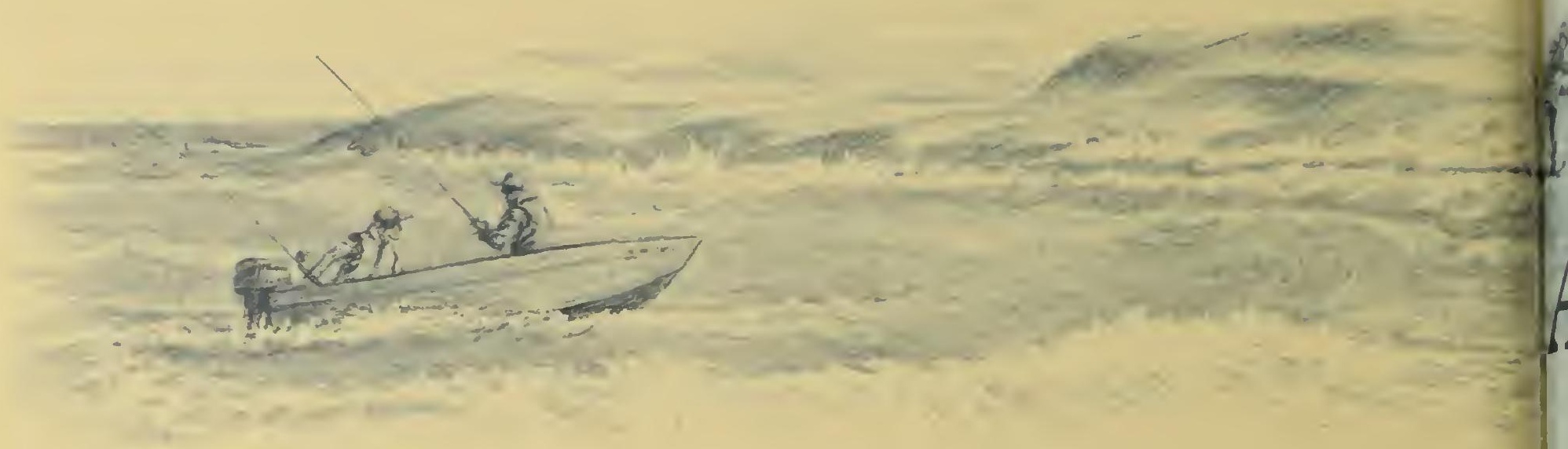

fishing rods and $6 / 0$ reels spooled with 60 - to 80 -pound test dacron line. When fishing with bait such as clams, add 4 to 5 feet of monofilament leader with large $8 / 0$ cod hooks. Ten-to 20 -ounce Swedish jigs or 16- to 20 -ounce bank sinkers may be needed to hold the bait on the bottom in 200 to 300 -foot depths.

Halibut that are hooked are occasionally lost due to stripped or broken lines, broken reels, or even twisted gaffs. Halibut frequently make only a short run with the bait immediately after being hooked. If this happens, the angler should retrieve as much line as possible and prepare for a prolonged battle with a powerful fish.

The thick, firm, and sweet-flavored steak of the Atlantic halibut is a popular, versatile meat that can be baked, broiled, grilled, sautéed, or steamed. To grill, take halibut steaks about 11/2 inches thick, flour, and baste with a mixture of melted butter (mayonnaise or margarine), lime juice, and white wine. Place the steaks on a hot, oiled grill for a total of 5 to 10 minutes per inch of thickness, turning once. The steaks are done when they flake.

Pan-baked halibut is also a favorite. Marinate one-inch thick steaks for several hours in $1 / 2$ cup of olive oil, freshly ground pepper, and seafood seasoning. Heat the marinade in an iron skillet, flour the steaks, and lightly brown them in the skillet. Place the skillet in an oven at 375 degrees F for 10 to 15 minutes, basting with the marinade. After cooking, add white wine to make a light sauce, and serve the halibut with a quartered lemon.

Michael R. Ross and Laura A. Thorpe

Department of Forestry and Wildlife Management

University of Massachusetts

Robert C. Biagi

Cooperative Extension

University of Massachusetts

Supported by Federal Aid in Sport Fish Restoration Act, through the Massachusetrs Division of Marine Fisheries, Department of Fisheries, Wildlife, and Environmental Law Enforcement, Executive Office of Environmental Affairs.

Produced by Cooperative Extension Communications Center. Liz Scott, design; Nancy Haver, Roy Lewando, illustration. University of Massachuserts, Unired States Department of Agriculture, and Massachuserts counties cooperating. Issued by E. Bruce MacDougall, Dean, in furtherance of the Acts of May 8 and June 30, 1914. Cooperarive Extension offers equal opportunizy in programs and employment. When a product name is mentioned, no discrimination is implied against similar or equivalent products. CR60:12/87-10.M

This publication is part of the Marine Recreational Fisheries series, available from the Division of Marine Fisheries, 100 Cambridge Street, Boston, MA 02202. 


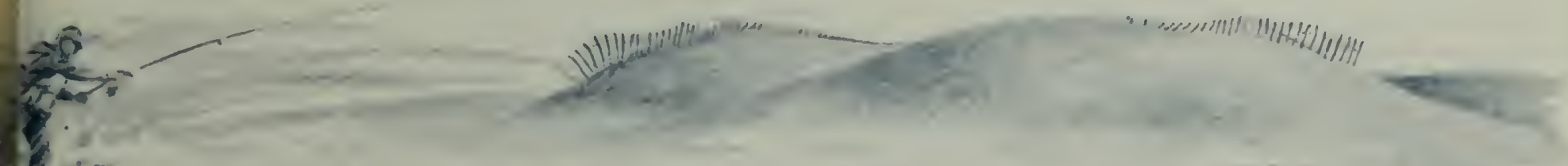

\section{Marine Recreational Fisheries of Massachusetts}

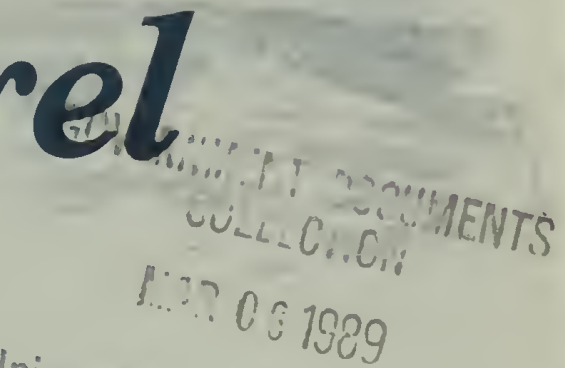

$\mathrm{T}$ he Atlantic mackerel, a popular recreational species because of its seasonal abundanceand voracious feeding habits, is native to both sides of the Atlantic Ocean. On our coast it ranges along the continental shelf from Labrador south to Cape Hatteras, North Carolina.

The swift-swimming mackerel has a streamlined body that is about five times as long as it is wide, a long, pointed head, and a mouth with numerous, small teeth. It has two large dorsal fins (A on diagram) and one anal fin (B). The tail is broad and deeply forked and is preceded by a series of finlets on the dorsal and ventral sides $(\mathrm{C})$. The tiny scales of the mackerel make the fish feel velvety when stroked.

The upper sides of the mackerel are dark gray to blue, and the head is almost black. Up to 33 blackish bands run vertically on each side of the body. This bold striped pattern easily distinguishes the mackerel from other recreational species in coastal Massachusetts waters. A dark stripe runs lengthwise along the body below the banded area. The lower sides and the gill covers are silvery, and the belly is silvery white.

Mackerel may grow as large as $71 \frac{1}{2}$ pounds, but the largest caught by angling in Massachusetts weighed 2 pounds 12 ounces. In recent years, the largest harvested by commercial boats have rarely weighed more than 3 pounds and measured more than 18 inches long, while most have not exceeded 12 to 14 inches. The maximum age for mackerel is about 20 years.

Many males and females reach sexual maturity at the age of 2 , and all do so by 4 . The fecundity (number of eggs produced in a given spawning season) of females increases as a function of age and size, with an individual female spawning from 550,000 to $1,000,000$ eggs per season.

\section{Habits}

$M$ ackerel are typically open-ocean fish, but large schools occasionally stray into estuaries and harbors in search of food. Most mackerel inhabit the inner half of the continental shelf, with none straying beyond the shelf's outer edge. Although frequently found near the water's surface, they also can be found as far down as 600 feet.

Mackerel range over extensive areas, traveling in schools that often contain many thousands of fish. All individuals within a specific school tend to be the same size. Mackerel swim at high speeds for extended periods of time while searching for food. For example, small 1 -year-old mackerel can swim at an average speed of 13 miles per hour. Since cruising speed increase:s significantly with age and size, scientists believe that conformity of body size within a specific school is necessary to allow all fish to maintain identical swimming speeds. 


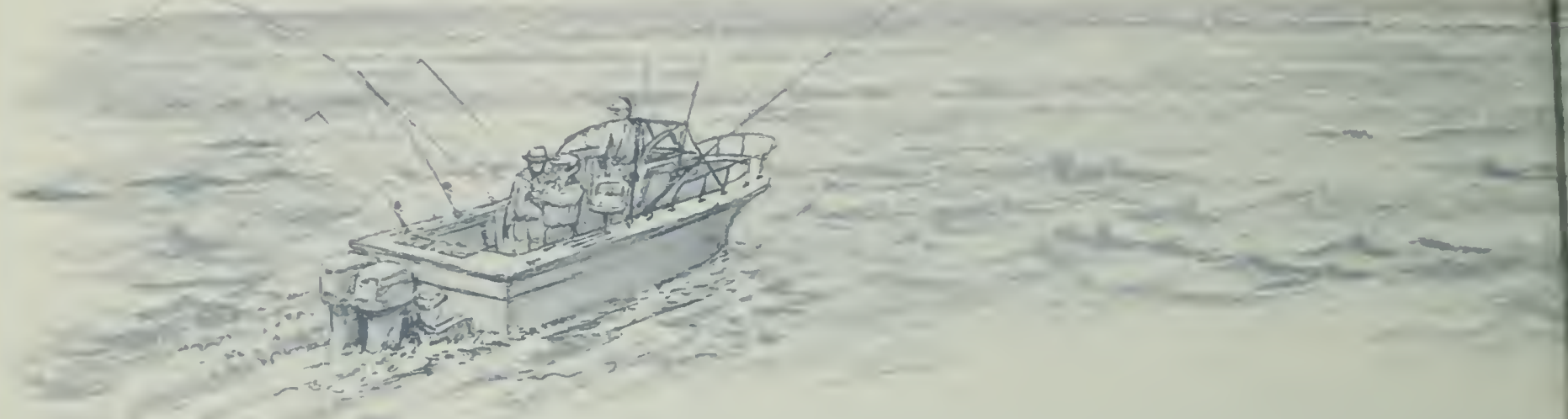

Mackerel migrate from southerly, offshore waters in winter to northerly, inshore waters in the warmer months. They typically arrive in our waters by the end of June; when they do not, anglers can expect low catches throughout the summer. Mackerel residing in Massachusetts waters in the summer move southward by September, but they are normally replaced for at least part of the fall by northern populations moving down from Canada. By late November, these northern fish move well offshore on the Continental Shelf to overwinter.

Mackerel reproduce from spring through summer, with the more northerly fish spawning later in the season. In coastal Massachusetts, spawning activity peaks in June. The mid-Atlantic Bight and the Gulf of St. Lawrence represent the two greatest spawning grounds for this species.

Mackerel spawn near the surface, and the eggs float in the water column. Hatching occurs within 90 to 102 hours when the water is 55 to 57 degrees F. Larval mackerel form into schools about 40 days after hatching, at which time they are approximately 2 inches long.

The mortality rates of larval mackerel fluctuate from year to year, but are generally very high. Fewer then 10 larvae out of every 1,000,000 eggs produced may survive years when wind-driven currents drive them far offshore over the Continental Shelf. Predation and starvation are other factors accounting for much of the death rate of young fish.

Young mackerel feed on microscopic copepods. As they grow, they feed on progressively larger prey. Adults will eat any fish smaller than themselves, feeding heavily upon small herring, sand lance, and young mackerel. They also commonly consume a variety of invertebrates such as copepods, crab larvae, squid, and shrimp. Their voracious feeding behavior leads them to strike at a wide array of baits thrown in their paths by anglers. In the spring, mackerel are thin-bodied because they have eaten very little during the winter; conversely, in late summer and fall they are usually fat from feeding upon abundant inshore foods.

Numerous animals feed upon mackerel, including whales, porpoises, mackerel sharks, thresher sharks, dogfish, cod, tuna, bluefish, and striped bass. Squid feed on small mackerel, and sea birds snatch this species from the surface waters.

\section{Management}

$\mathrm{T}$ he Atlantic mackerel has exhibited rapidly fluctuating population densities since colonial times. Fluctuations typically occur more rapidly and to greater extremes than do those of many other fish. Peak years of abundance usually have produced record harvests; for example, in $1885,100,000,000$ pounds were landed in Massachusetts ports alone. Such periods were normally followed by rapid reductions in catch; after 1885, harvest levels dropped to as low as 580,000 pounds for the entire east coast by 1910. In 1916, the catch was 25 times greater than that in 1910 . Gulf of Maine harvests in peak years were occasionally 50 to 100 times greater than in poor years.

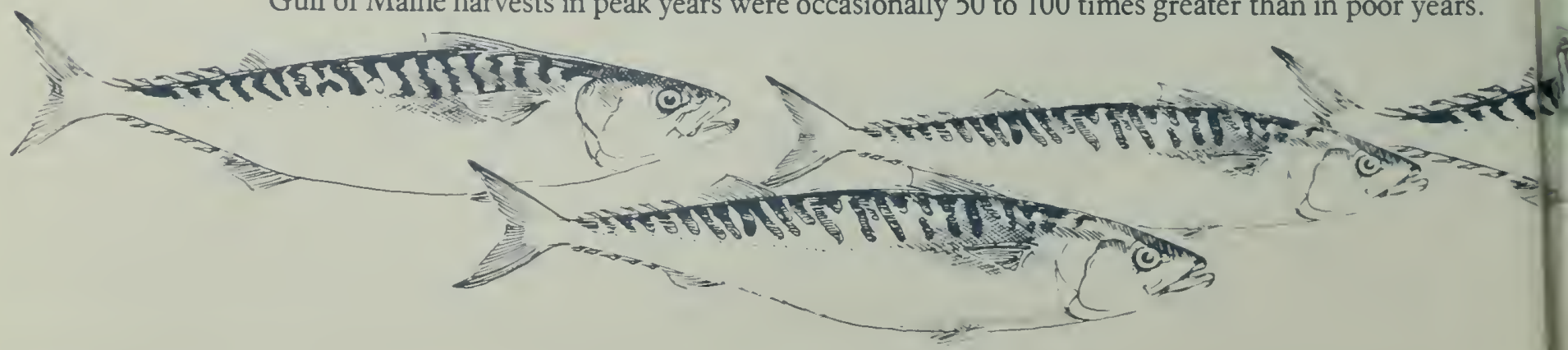


A medium spinning rig spooled with 15-pound test line is best for casting, although adventuresome anglers may use medium- or light-action spinning rods with a single 1-ounce mackerel jig or a saltwater fly rod rigged with a streamer. Any metal lure that resembles a sand eel or other bait fish can be used when casting (for example, a miniature Hopkins, Kastmaster, or leadhead, or even small plugs). After casting, lures should be allowed to flutter down through the water for a moment, then jerked and retrieved rapidly.

Many anglers fishing from a boat use the mackerel tree, which is a small diamond jig preceded by 2 or more $1 / 0$ surge tube worms. The tree is jigged so that it resembles a larger fish chasing small bait fish. Typically the jig is dropped to the bottom, lifted with a jerk, and allowed to settle; this action should be repeated at a rapid pace.

Mackerel can also be pursued with bait such as sand eels, sea worms, squid, or small fish on long shank hooks with on-line sinkers. Mackerel strike hard and then momentarily release the bait before attempting to swallow it. Therefore, the greatest success is achieved by setting the hook on the second strike.

Mackerel lose their flavor rapidly if they are not kept cool. Fish should be iced immediately upon capture if possible. If ice isn't available, they should be kept wet in a burlap bag that is frequently dampened; evaporation from the bag will help keep the fish cool.

Salted mackerel with potatoes and biscuits is a traditional New England Sunday breakfast. This species is also enjoyed by many who prefer a more conventional approach to eating fish. The mackerel carries high concentrations of Omega-3 oil, valued for its important impact upon human cardiovascular health. Many people prefer marinating mackerel in citrus juices to lighten the full flavor that the oil imparts to the flesh. Marinated mackerel that has been cooked skin down on a covered grill provides the angler with a pleasurable ending to a day's successful fishing.

Michael R. Ross and Laura A. Thorpe

Department of Forestry and Wildlife Management

University of Massachusetts

Robert C. Biagi

Cooperative Extension

University of Massachusetts

Supported by Federal Aid in Sport Fish Restoration Act, through the Massachusetts Division of Marine Fisheries, Department of Fisheries, Wildlife, and Environmental Law Enforcement, Executive Office of Environmental Affairs.

Produced by Cooperative Extension Communications Center. Liz Scott, design; Nancy Haver, Roy Lewando, illustration. University of Massachusetts, United States Department of Agriculture, and Massachusetts counties cooperating. Issued by E. Bruce MacDougall, Dean, in furtherance of the Acts of May 8 and June 30, 1914. Cooperative Extension offers equal opportunity in programs and employment. When a product name is mentioned, no discrimination is implied against similar or equivalent products. CR60:12/87-10:M

This publication is part of the Marine Recreational Fisheries series, available from the Division of Marine Fisheries, 100 Cambridge Street, Boston, MA 02202. 
UM4:2: M34/Marlin, Wlite

University of Massachusetts Cooperative Extension - Massachusetts Division of Marine Fisheries

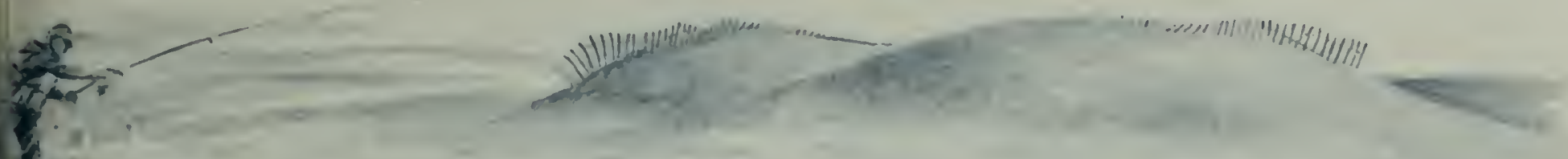

\section{Marine Recreational Fisheries of Massachusetts}
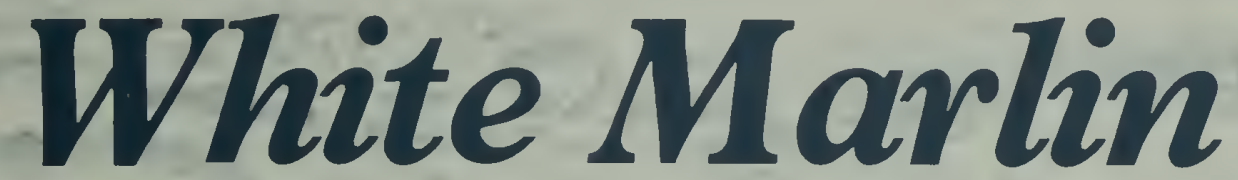

University

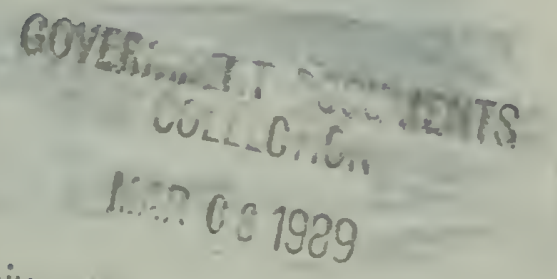

$\mathrm{T}$ he white marlin, a highly prized game species of the eastern coast of the United States is native to the western Atlantic Ocean from the northern coast of Brazil to Cape Cod. It is abundant throughout the year from the Caribbean to southern Florida, and is seasonally abundant from Cape Hatteras, North Carolina, to Cape Cod.

The white marlin resembles the larger and more southerly distributed blue marlin, but differs in having a rounded instead of a pointed anterior dorsal fin (A on diagram) and lighter coloration on its sides and belly. The white marlin has a much shorter "sword" (elongate projection of the snout and upper jaw) and a much longer dorsal fin than the swordfish; it also has scales, whereas adult swordfish are scaleless.

The white marlin is bright greenish blue dorsally, fading to pale blue laterally, and to white on its belly. The sides are striped with as many as a dozen light blue or purple vertical bands. The dorsal fin is blue with dark spots.

The largest white marlin landed by a recreational angler in Massachusetts waters weighed 131 pounds. However, most weigh less than 60 pounds. Little is known about the growth rates of this species, but females tend to grow larger than males. The maximum age is thought to be somewhat greater than 10 years.

Female white marlin reach sexual maturity at the weight of about 44 pounds. The fecundity (number of eggs produced in a season) of females increases with age and weight, with a 60-pound female producing about 5,125,000 eggs and an 80-pound female about 10,500,000 eggs in a year.

\section{Habits}

W hite marlin are oceanic, ranging from coastal waters to well beyond the continental shelf of the U.S. They are transient in Massachusetts, moving northward to the southern New England region in the summer and migrating southward by the beginning of fall. The marlin occasionally occurs as far north as Nova Scotia, but the waters off the southern and eastern shores of Cape Cod are its normal northern limit. Major currents appear to play an important role in migratory and distribution patterns of this species, which is frequently found in greatest abundance within or near the Gulf Stream when along our eastern coast. White marlin are often found 


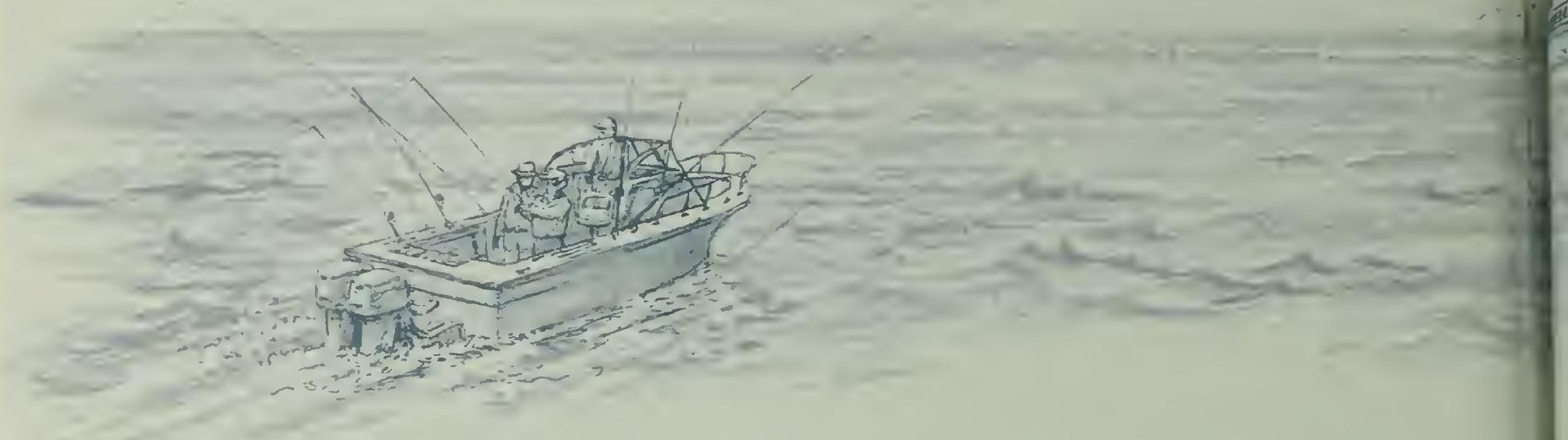

in shoals, submarine canyons, or steep drop-offs of the ocean floor where current boundaries, upwellings, and thermal fronts tend to concentrate food resources.

White marlin spawn during April and May throughout the Caribbean, Gulf of Mexico, and in the straits of Florida. Little is known about the survival of larvae and juvenile fish. Each year up to $40 \%$ of all adult white marlin die either from fishing or natural causes.

White marlin larvae feed on microscopic organisms until they are large enough to pursue larger prey. Adults feed mainly on small schooling species, including herring, squid, and anchovies, but the composition of their diet can differ markedly from one region to another.

\section{Management}

A recreational fishery for white marlin has existed off the coast of the U.S. since the early 1900 s. However, prior to 1950 , this fishery was limited to a few areas. Since then, a coast-wide fishery has developed for this species.

In recent years, competition for the white marlin has intensified between the recreational fishery, the yellowfin tuna or swordfish longline fisheries that capture it as by-catch (incidental catch while fishing for other species) in more southern waters, and a directed commercial fishery. Mortality due to commercial harvest is felt to be reducing this resource to potentially critical levels. The average total harvest in the years 1977 to 1979 was about half the average for the previous 10 -year period (which was approximately $2,200,000$ pounds or 44,000 fish). Total harvest in the 1980s has increased somewhat, but remains below that of the 1966 to 1976 period.

The New England, Mid-Atlantic, South Atlantic, Caribbean, and Gulf of Mexico Regional Fishery Management Councils have prepared a draft Atlantic Billfish Fishery Management Plan that addresses the conservation of white marlin. This proposed plan contains regulations meant to protect the white marlin resource for recreational harvest. Regulations in the plan include:

1. prohibiting the sale of any landed fish (in order to prevent further development of a commercial market for this species),

2. requiring the release of all fish weighing less than 50 pounds (in order to reduce significantly mortality caused by the recreational fishery), and

3. prohibiting longline and drift net commercial vessels from keeping it as by-catch (in order to maximize the release of live fish by the commercial boats most likely to catch them). Since the white marlin is oceanic, the Atlantic population extends far beyond U.S. territorial waters. For this reason, the proposed plan suggests that the management regime for white marlin should complement any initiatives undertaken through international agreements.

In December 1987, previous to final disposition of the draft management plan, the New England Council voted to prohibit the sale of white marlin. This followed similar action taken in the summer of 1987 by the Massachusetts Division of Marine Fisheries to protect this resource in Massachusetts waters. 

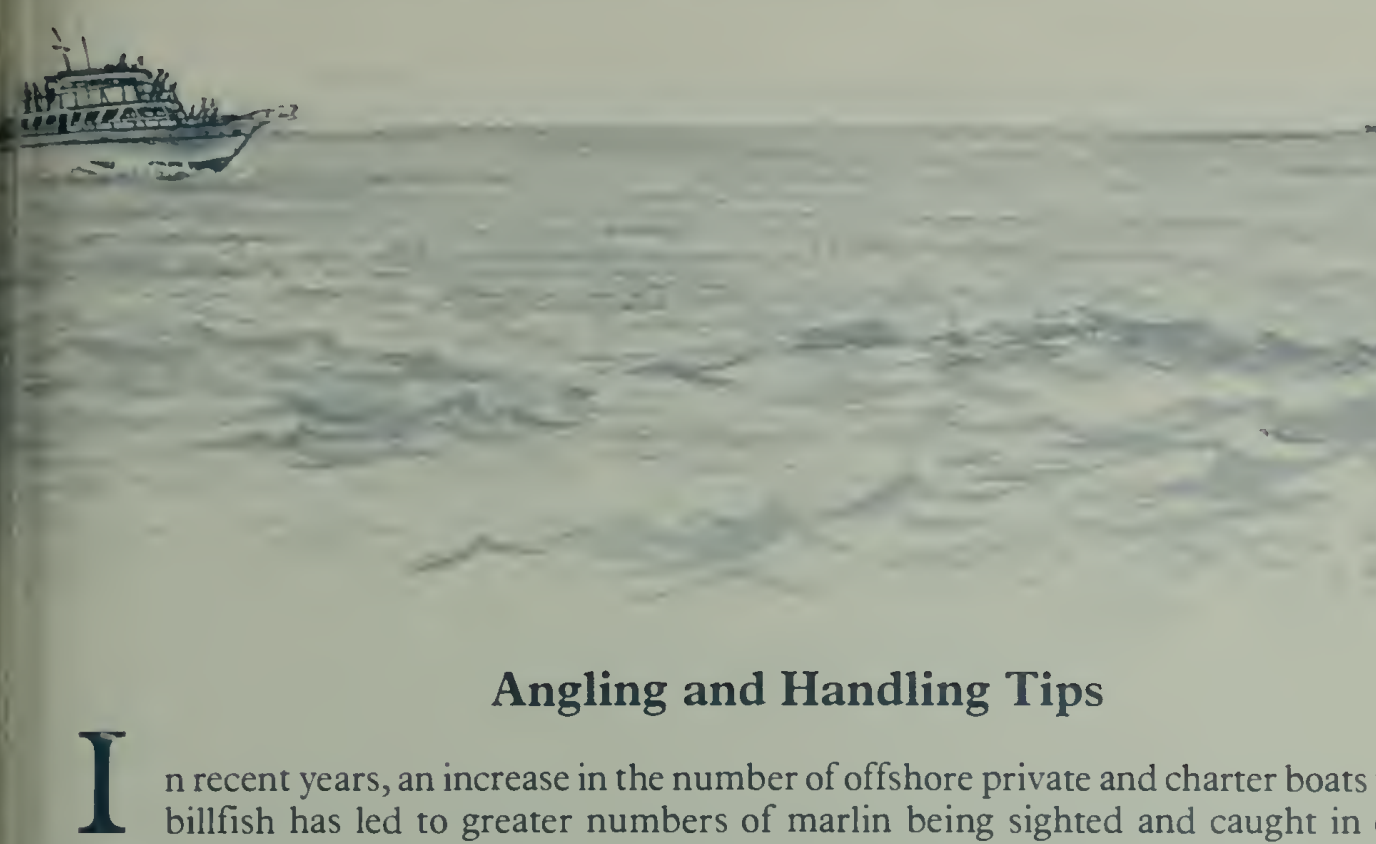

\section{Angling and Handling Tips}

$\mathrm{n}$ recent years, an increase in the number of offshore private and charter boats that fish for billfish has led to greater numbers of marlin being sighted and caught in our waters. Anglers usually call upon an array of indicators to locate this pelagic species. In order to have a successful trip, the angler must be able to correctly interpret a number of factors, such as: water temperature changes, weed lines, water color changes, fathom curves, and the presence of schools of bait fish or of sea birds. Therefore, many prefer to charter an experienced boat and captain when fishing for white marlin.

Unlike the closely related blue marlin, that tends to travel singly, white marlin occasionally gather in small groups while feeding. When white marlin are spotted, careful presentation of bait or lures can often lead to a strike.

Those anglers that use the more traditional method of trolling prefer stout rods and reels that can handle 450 yards of 50 pound test line. Anglers experiment with sizes, shapes, styles, and colors of lures to achieve the greatest success. Hex heads, daisy chains, green machines, and smokers are all favored lures.

Casting live or frozen bait to fish seen finning the surface waters is preferred by many anglers. Spinning outfits fitted with 20 pound test line are typically used when casting. The line is doubled directly to a size $6 / 0$ offset "sailfish" hook. Live tinker mackerel, scup, and northern ballyhoo, or frozen spanish minnows or mullet are commonly used baits.

In the U.S., marlin historically have been considered a nonfood gamefish; thus, anglers in the past typically released their catch. Catch-and-release is still being promoted as one means of conserving the

marlin resource. However, as consumers become more willing to experiment with fish that have traditionally not been eaten, more white marlin are being retained as seafood. The marlin is esteemed in the Caribbean and Latin America, where it traditionally has been grilled, broiled, or baked. Smoked marlin is also considered a delicacy. Marlin can be cooked using any recipe written for swordfish, mako shark, or even fresh tuna.

Marlin kabobs offer an interesting dining change. Marinate chunks of marlin in olive oil and lemon juice for at least one hour. Alternate the meat on the skewer with vegetables such as zucchini, yellow squash, onions, green peppers, tomatoes, and broccoli; then brush with the marinade. Season and grill on a hot fire, or broil, turning and basting for 15 to 20 minutes. 


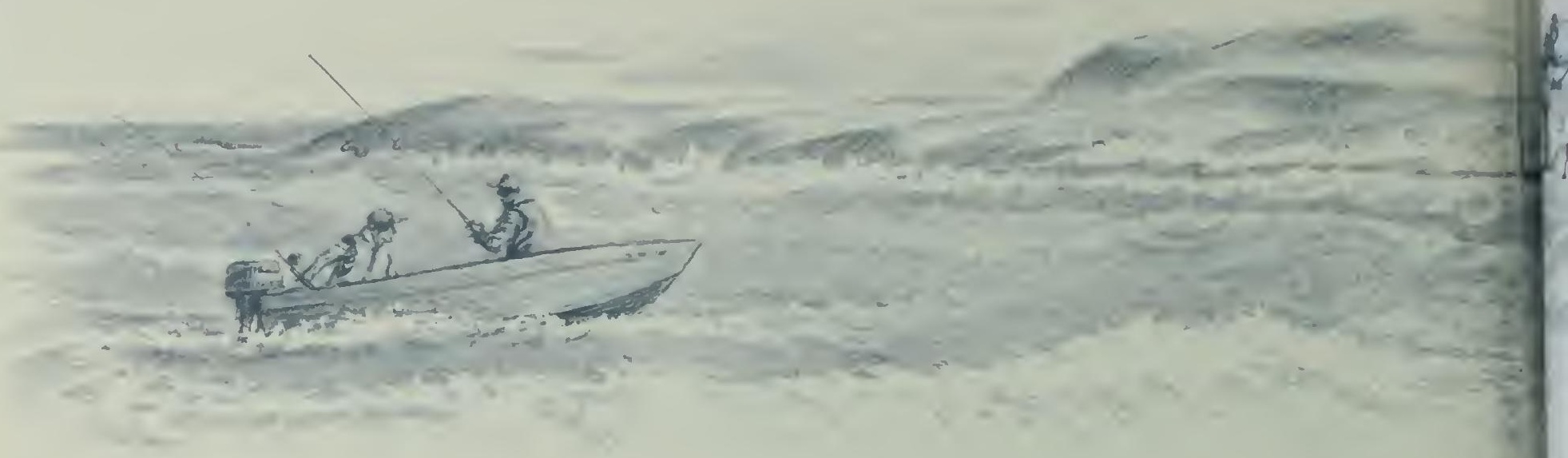

Michael R. Ross and Laura A. Thorpe

Department of Forestry and Wildlife Management

University of Massachusetts

Robert C. Biagi

Cooperative Extension

University of Massachusetts

Supported by Federal Aid in Sport Fish Restoration Act, through the Massachusetts Division of Marine Fisheries, Department of Fisheries, W'ildlife, and Environmental Law Enforcement, Executive Office of Environmental Affairs.

Produced by Cooperative Extension Communications Center. Liz Scott, design; Nancy Haver, Roy Lewando, illustration. University of Massachusetts, United States Department of Agriculture, and Massachusetts counties cooperating. Issued by E. Bruce MacDougall, Dean, in furtherance of the Acts of May 8 and June 30, 1914. Cooperative Extension offers equal opportunity in programs and employment. When a product name is mentioned, no discrimination is implied against similar or equivalent products. CR60:12/87-10.11

This publication is part of the Marine Recreational Fisheries series, available from the Division of Marine Fisheries, 100 Cambridge Street, Boston, MA 02202. 
$4.2: M 34 / M$ m $k$.

University of Massachusetts Cooperative Extension - Massachusetts Division of Marine Fisheries

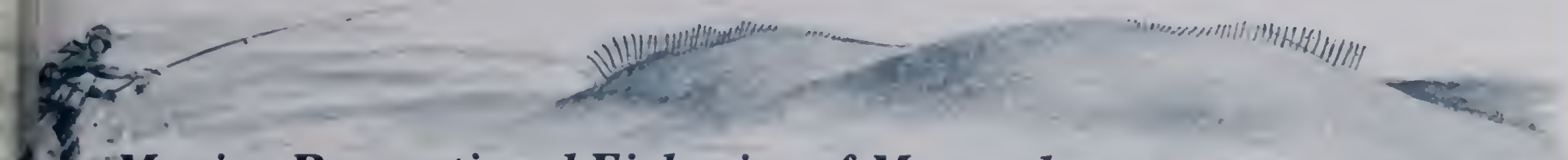

\section{Marine Recreational Fisheries of Massachusetts}

\section{Monkfish}

$\mathrm{T}$

he monkfish, also known as the goosefish or angler, is native to the eastern coast of Nort

America from Newfoundland to North Carolina. It also inhabits the Gulf of Mexico and waters off Brazil.

The monkfish is so unique in appearance, it cannot be confused with any other fish of coastal

Massachusetts. It has an enormous head and mouth and a flattened body of strikingly modest

proportion in relation to the head. The eyes are on top of the head, pointing upward.

The lower jaw projects so far beyond the upper that its 2 to 3 rows of slender,

curved teeth are

exposed even

when the

mouth is

closed. The

upper jaw also

possesses large, curved teeth,

and there are several rows of thorn-like teeth on the roof of

the mouth. The gill openings, positioned behind the pectoral fins (fins

marked A on diagram), lack the gill covers seen in most bony fish. The

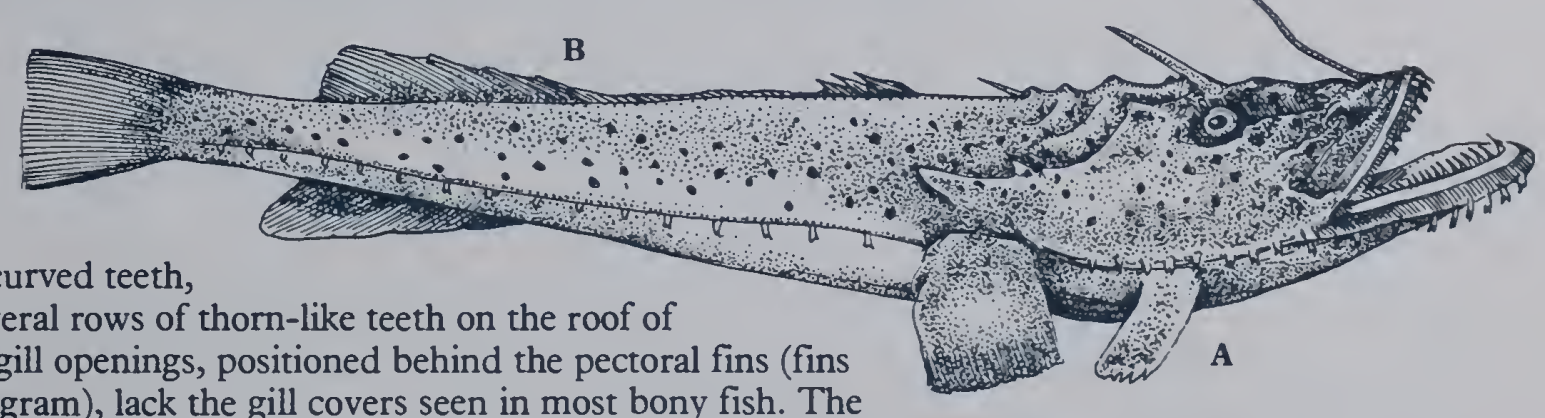

dorsal fin (B) is preceded by a row of 3 elongate rays, the most anterior of which has a fleshy pad that is used to lure small fish close to the huge mouth.

A monkfish is usually brown dorsally and pale to a white on its belly. The tips of the dorsal fins, pectoral fins, and tail are black.

Monkfish can reach 4 feet in length and up to 50 pounds in weight. They are 6 to 9 inches long at $1 \frac{1}{2}, 14$ to 19 inches long at $2 \frac{1}{2}$, and 21 inches long at 3 years of age.

Both males and females reach sexual maturity after they have reached 30 inches or more in length, at which time they are at least 4 years old. Fecundity (the number of eggs produced in a given season) increases with age and size. Females may produce over 1,300,000 eggs per season.

\section{Habits}

I

$\mathrm{n}$ the southern New England region, monkfish are found from a few feet below tide line to depths of over 2,000 feet on the Continental Slope. They live on various types of substrate, including sand, gravel, rocks, beds of broken shells, and mud. Monkfish are tolerant of a wide range of temperatures; they have been collected in waters from as cold as 32 to as warm as 70 degrees F. However, even though monkfish do not display temperature-driven seasonal migrations, they may descend into deeper waters during summer or winter to avoid the temperature extremes found in inshore waters at those times of year.

Monkfish reproduce in shallow to deep water from spring through early fall. The timing in a given region depends upon latitude; fish in New England spawn from late June to mid-September. Large masses of eggs are shed in ribbon-like veils of mucus that may be 25 to 36 feet long and 2 to 3 feet wide. Within each mass eggs are arranged singly or in small groups in separated, hexagonal 


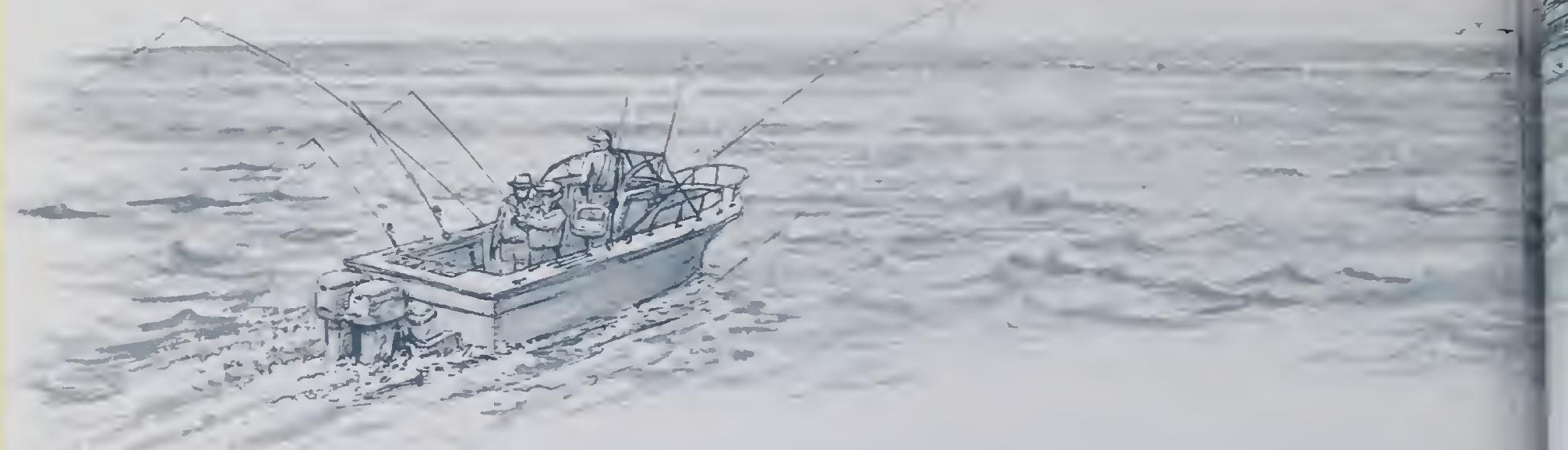

compartments. The egg masses float within the water column. Soon after they hatch and their yolk sacs are resorbed, fry begin feeding upon copepods, crustacean larvae, and glass worms. At this point the fry are about 0.1 inch long. Fry metamorphose into bottom dwellers by the time they have grown to about 2 inches in length.

The voracious monkfish becomes a fish eater by the time it starts bottom dwelling. Adults feed upon a variety of fish such as spiny dogfish, skates, eels, sand lance, herring, mackerel, silver hake, cod, haddock, flounders, tautog, and sea bass. "Angler" is a well-earned nickname for this species, which often lies motionless in eel grass, waving the "lure" at the end of its first dorsal ray. As small fish approach, the monkfish gapes its mouth and literally sucks them in.

Monkfish also eat numerous sea birds such as comorants, herring gulls, scoters, loons, and diving water fowl. As a result, they are sometimes called "goosefish," although a full grown goose has never been found in the stomach of a landed monkfish.

It is not unusual for a monkfish to contain up to half its own weight in its stomach. One specimen taken in a net contained 21 flounders and a dogfish, while another had engulfed 7 ducks. Its huge mouth also allows the monkfish to capture extremely large food items. One analyzed specimen had eaten a 12-pound, 31-inch-long haddock; another had a winter flounder nearly its own size in its stomach. In spite of occasional catches of spectacularly large prey, the bulk of the monkfish's diet apparently consists of large numbers of small fish.

\section{Management}

$\mathrm{H}$ istorically, monkfish populations along the East Coast of the United States have not been commercially harvested, as this species was not considered to be marketable. This is in contrast to the closely related European monkfish, which was heavily exploited as early as the 1940s due to the high price it brought in English and Scottish ports. In recent years, the collapse of the populations of high-value fish in the northwest Atlantic has led to an increase in the market value of other species. Thus, the monkfish now commands a high price due to its greater acceptance as a food fish. However, it is so sparsely distributed that no fishery has developed that is specifically directed toward its harvest. The monkfish is typically landed as incidental catch by commercial vessels directing their efforts toward other fish. Likewise, the recreational harvest of monkfish consists mostly of individuals being by anglers fishing for other species. Therefore, the numbers landed each year are extremely modest.

Although the commercial harvest may be increasing, there is no available evidence that the monkfish off the Massachusetts coast are being reduced to critical levels. Because of this, regulations governing the recreational or commercial harvest of this species have not been established as of 1988 . 


\section{$+\cdots$}

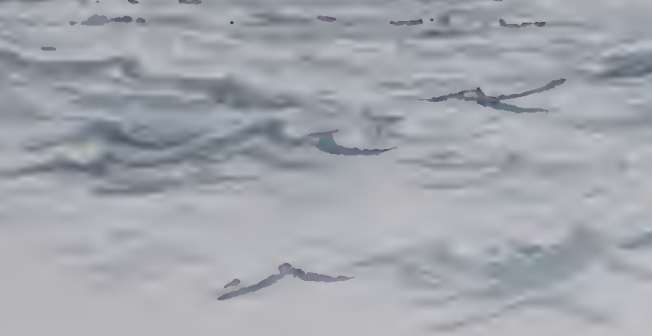

\section{Angling and Handling Tips}

$M$

onkfish are typically captured incidentally by anglers using live bait in pursuit of other

fish. This species is encountered so infrequently that few methods have been developed specifically for pursuing and landing it. Since it typically eats a wide variety of organisms, the monkfish can be hooked with many different types of live bait that are being fished near the bottom for other large, predatory species.

Although called the "angler," this species is considered by most people to be far uglier than any angler one might ever encounter! The monkfish's bizarre appearance has led more than one inexperienced person to dump it over the side; however, the joke is on the angler, for over the side of the boat went one of the best chunks of thick fillet that the sea can produce. Its firm, white meat has been held in esteem in Europe for years. Its firm texture is considered similar to that of the lobster; hence, it is referred to as "poor man's lobster." It is often found on restaurant menus as "Lotte," or in supermarkets under its own name, and is frequently included in dishes such as Spanish "Paella" and the French bouillabaisse.

After monkfish are filleted and skinned, they become a versatile dish that can be sautéed in a pan or wok; broiled; added to chowder or stew; poached; or cut into strips, dipped in batter, and deep fried. It is excellent when chunked and added to a kabob, since it stays together like red meat does when grilled.

For an interesting appetizer, try monkfish cocktail. Bake a thick fillet in a 350 degree oven for 10 minutes per inch of thickness. After the fillet cools, slice it into short strips about the size of shrimp. Chill, arrange on a bed of lettuce, and serve with a seafood cocktail sauce as monk "shrimp."

Michael R. Ross and Laura A. Thorpe

Department of Forestry and Wildlife Management University of Massachusetts

Roberi C. Biagi

Cooperative Extension

University of Massachusetts

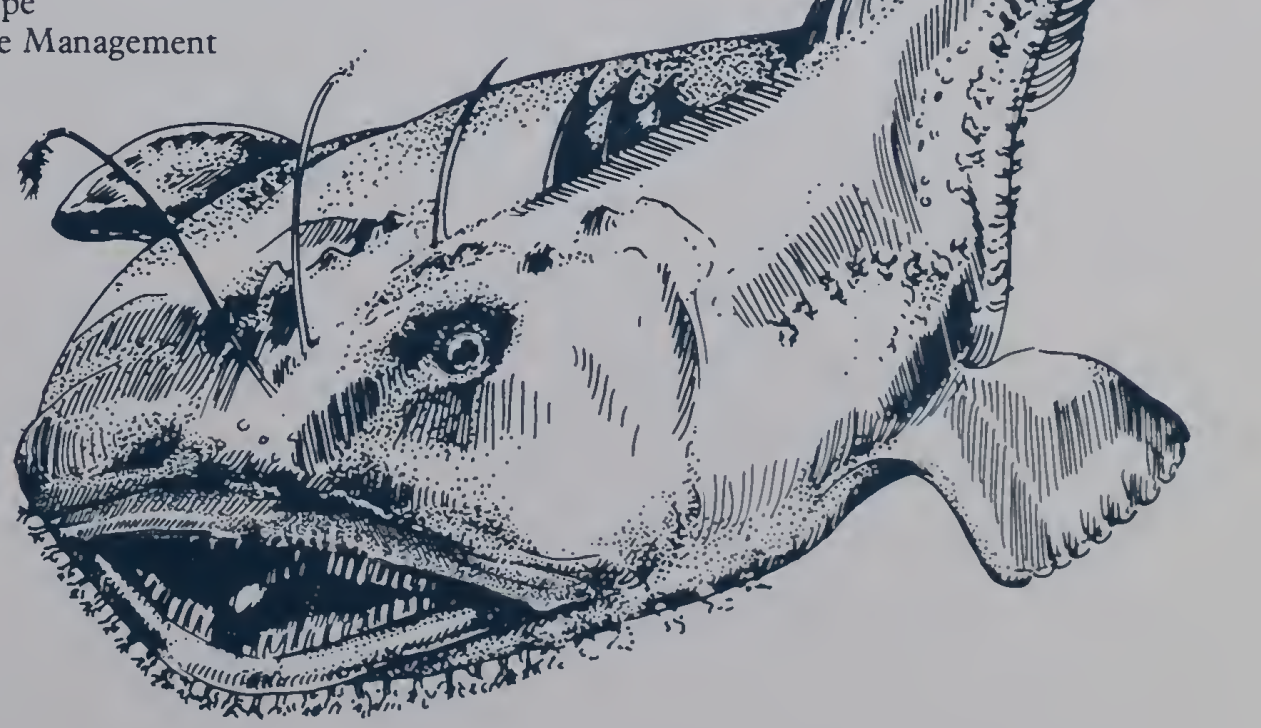




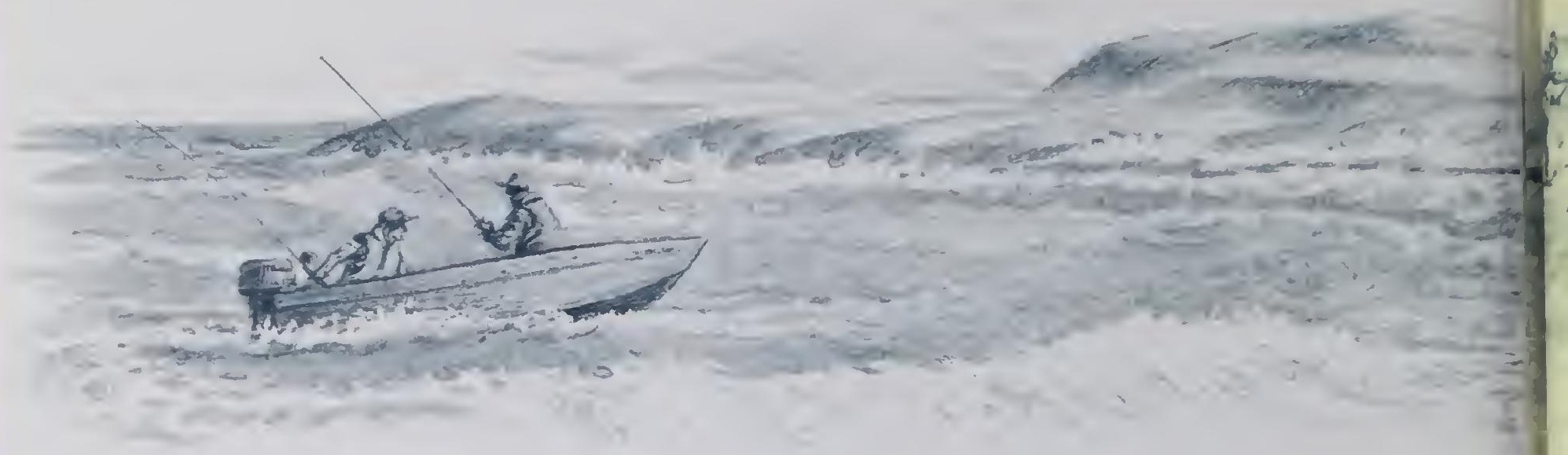

Supported by Federal Aid in Sport Fish Restoration Act, through the Massachusetts Division of Marine Fisheries, Department of Fisheries, Wildlife, and Environmental Law Enforcement, Executive Office of Environmental Affairs.

Produced by Cooperative Extension Communications Center. Liz Scott, design; Nancy Haver, Roy Lewando, illustration. University of Massachusetts, United States Department of Agriculture, and Massachusetts counties cooperating. Issued by E. Bruce MacDougall, Dean, in furtherance of the Acts of May 8 and June 30, 1914. Cooperative Extension offers equal opportunity in programs and employment. When a product name is mentioned, no discrimination is implied against similar or equivalent products. CR60:12/87-10.M

This publication is part of the Marine Recreational Fisheries series, available from the Division of Marine Fisheries, 100 Cambridge Street, Boston, MA 02202. 


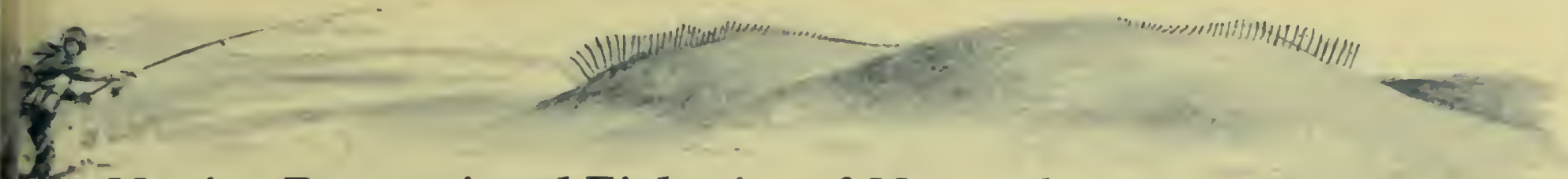

\section{Marine Recreational Fisheries of Massachusetts}

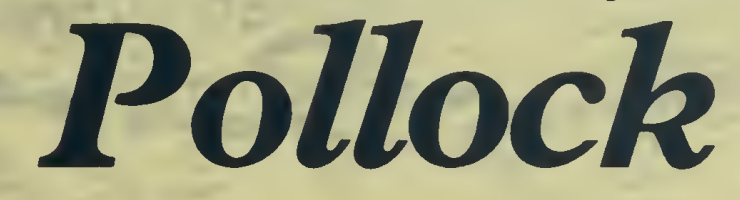

$\mathrm{T}$

he pollock (also called "Boston bluefish"), a popular fish available to anglers from inshore bays and estuaries to offshore banks, occurs on both sides of the North Atlantic. In the northwestern Atlantic, it is found as far south as the Chesapeake Bay and as far north as the southern Labrador and western Greenland coasts. The major center of abundance in the western Atlantic occurs in the Gulf of Maine on the offshore banks and along the entire coastline from Nantucket Shoals and Cape Cod to Cape Sable, Nova Scotia.

This species is one of the more deep-bodied members of the cod family. The lower jaw, projecting beyond the upper, has a small chin barbel ("whisker") in young fish that is usually missing in larger fish. The pollock has 3 separate dorsal fins (A on diagram) and 2 separate anal fins (B), as do the cod, haddock, and tomcod. The first and the second dorsal fins are triangular in shape, with the second noticeably longer than the first. The tail is indented along its posterior edge, with both lobes of the fin

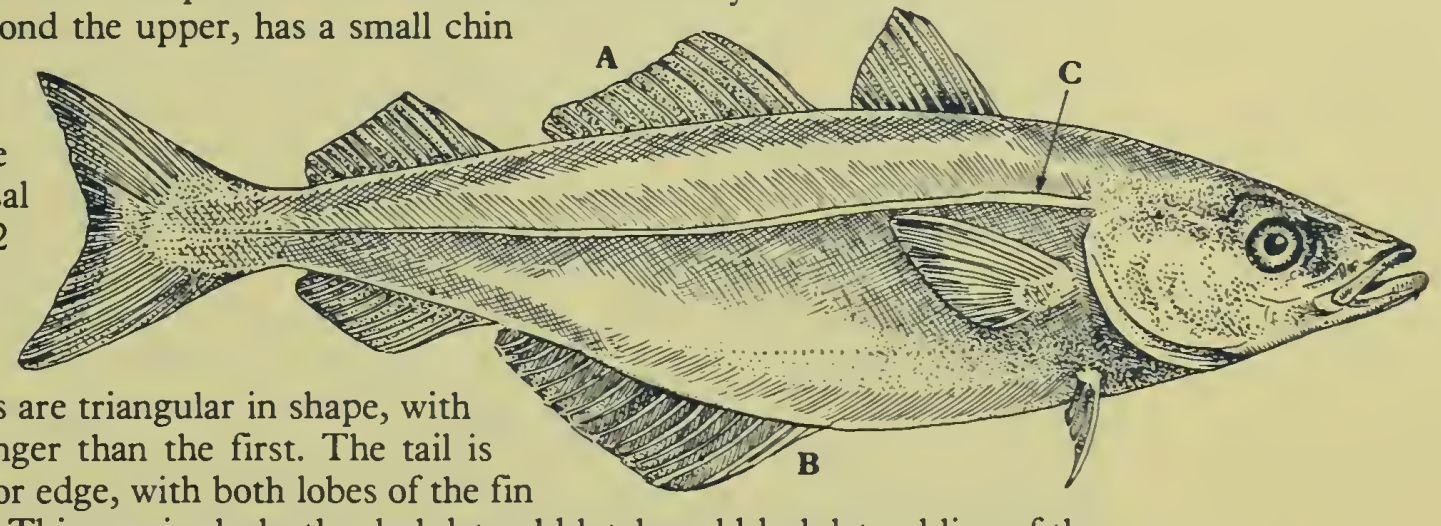
being pointed or angular. This species lacks the dark lateral blotch and black lateral line of the haddock, the rounded tail and equal-sized dorsal fins of the tomcod, and the overhanging snout and shorter lower jaw of the cod.

Pollock range from olive green to brownish green dorsally and pale gray to yellow laterally. The belly is silvery. The lateral line ( $\mathrm{C}$ on diagram), a series of sensory pores used to detect disturbances in the water, is lighter than the upper sides of the body. Young pollock are darker and yellower on the lower sides than are older, larger pollock.

The largest pollock landed by hook-and-line in Massachusetts weighed 44 pounds 7 ounces and was caught at Cashes Ledge. Pollock grow about 5 inches a year for the first 3 years of life, 2 to 4 inches a year for the next 3 years, and about 1 to 2 inches a year thereafter. A 5 -year-old pollock may weigh 4 to 5 pounds and measure up to 25 inches in length, and a 9 -year-old 8 to 10 pounds and 30 inches in length. The maximum age reached by pollock is about 19 years.

Male pollock become sexually mature at 4 to 7 years, and females at 5 to 7 years of age. Fecundity (the number of eggs a female produces in a given season) increases with age and size. Large females may produce as many as 4,000,000 eggs in a spawning season. 


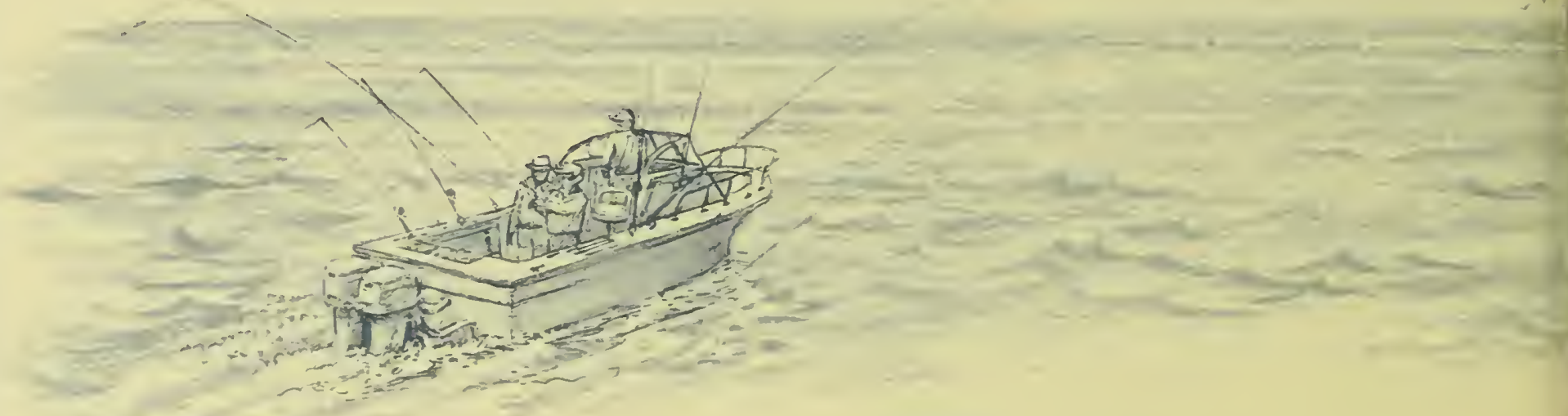

\section{Habits}

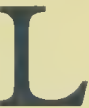

ike other members of the cod family, pollock live on or near the bottom in areas of rocky substrates. They are found from shallow waters to depths as great as 600 feet, depending upon water temperatures and food availability. Pollock can tolerate temperatures near 32 degrees $\mathrm{F}$, but off the Massachusetts coast they are most abundant in temperatures from 51 to 68 degrees $\mathrm{F}$.

Large schools of pollock migrate inshore during spring, and move to offshore waters in the colder months. Large schools of younger fish called "harbor pollock" move into estuaries and shallow bays in the spring. They remain there until dropping inshore temperatures in the fall force them to move offshore to deeper, and at that time of the year warmer, waters.

The western Gulf of Maine region is a major pollock spawning area. The mouth of Massachusetts Bay, southeast of Gloucester to the eastern slope of Stellwagen Bank, is a particularly active area. Pollock generally spawn during the autumn and early winter in water 90 to 300 feet deep. Spawning begins when the water cools to about 48 to 59 degrees $F$. The buoyant eggs hatch 6 to 9 days after fertilization, and the larvae remain near the surface for at least 3 months before moving downward to become bottom-dwelling juveniles.

Pollock are largely daytime sight feeders. Yearlings eat microscopic crustaceans such as copepods. Adults feed on large pelagic crustaceans such as shrimp and small fish such as herring, sand lance, cod, haddock, and hake. Juvenile pollock occasionally are seen chasing schools of smelt through estuaries in the fall. Unlike the more demersal (bottom-dwelling) cod, pollock will pursue schools of small fish at any depth, occasionally driving them to the surface of the water where frantic splashing can be seen as the prey attempt to escape. Pollock are noted for their voracious behavior while feeding; one 9-inch specimen had 77 two-inch herring in its stomach when it was captured during a feeding episode.

\section{Management}

$\mathrm{H}$ istorically, the pollock had modest market value and was commercially harvested largely as by-catch (caught while fishing for other species). As other coastal fisheries have declined in abundance, the pollock has developed a higher market value and has become the target of moderate commercial fishing effort. Commercial landings from the Scotian Shelf to Georges Bank have gradually increased from around 50,000,000 pounds in 1968 to over 140,000,000 pounds in 1985 . This increase seems to have had modest effect on pollock abundance; the biomass of age 2 and older pollock fluctuated slightly from the late 1970s to 1980, then increased significantly (as shown in the figure).

Recreational harvest varied from less than $1 \%$ to $3 \%$ of the total yearly harvest of pollock from 1979 to 1985 . The total yearly recreational harvest peaked at about $2,680,000$ pounds in both 1982 and 1983. 


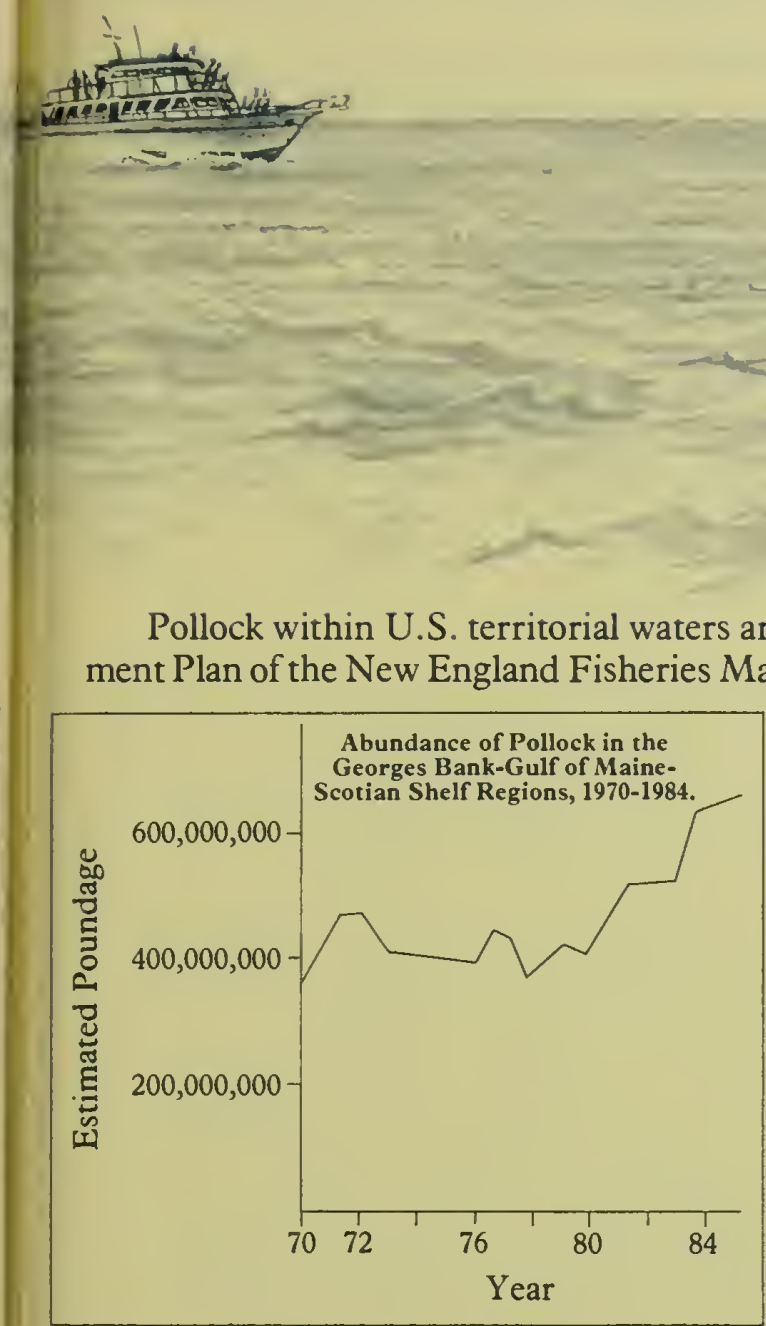

Pollock within U.S. territorial waters are managed under the Multispecies Fishery Management Plan of the New England Fisheries Management Council. Regulations controlling commercial harvest include a 19-inch minimum legal size limit, mesh size regulations, and an area closure that was established to protect spawning of the depleted haddock fishery. Due in part to the modest level of total harvest that is attributed to recreational anglers, it has not been necessary to regulate recreational harvest of the coastal pollock resource managed by the Massachusetts Division of Marine Fisheries as of 1987.

\section{Angling and Handling Tips}

$\mathrm{P}$ ollock are aggressive, strong fighters that frequently strike at fast-moving lures. Anglers pursue pollock from party boats, private boats, or shoreline. Inshore fishing lasts from spring to very late fall, depending upon water temperatures, the presence of bait fish, and the fortitude of the angler. The larger pollock tend to gather in deeper, more offshore waters, while the younger fish ("harbor pollock") frequent areas along the shoreline.

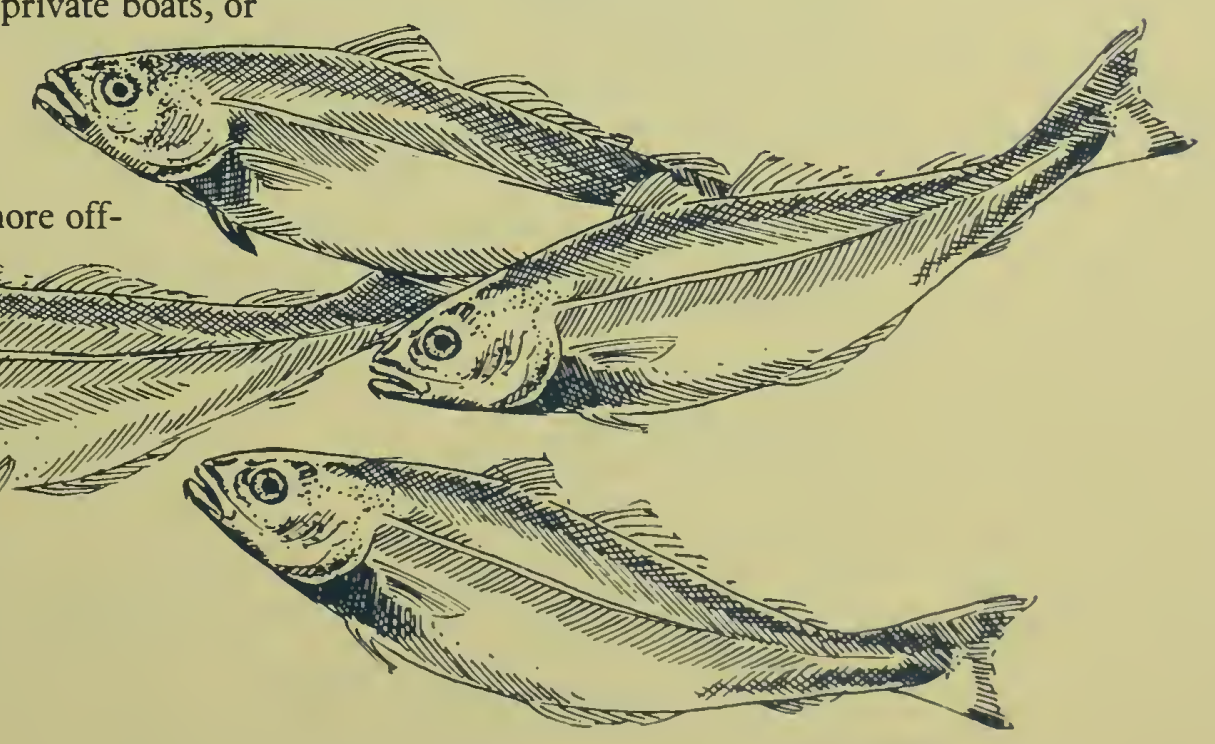




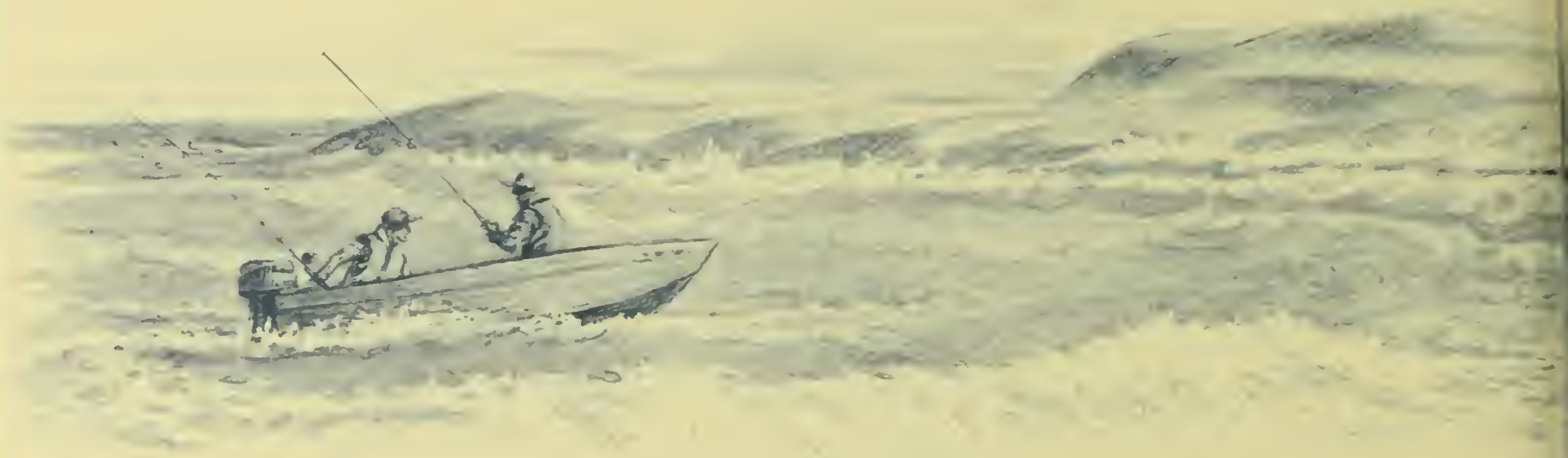

In deeper water, pollock are taken with the same tackle and rigs as those used for cod. A medium/ heavy 7-to 9-foot "cod rod" and a 4/0 conventional reel spooled with 40- to 50-pound test dacron line are commonly used by anglers. Lures are especially effective on pollock. A 10 - to 20 -ounce Vike or Norwegian-type jig with a dropper/teaser tied about 3 feet above the jig is a particularly popular rigging. Attaching the teaser to a 2-way swivel by a split ring or a bead chain helps make the action more effective and does not weaken the line as a dropper can. When fishing with this rig, allow it to settle to the bottom; then alternately retrieve a small amount of line, jig the lure, and allow it to flutter downward before repeating the sequence. Pollock most frequently strike during the flutter downward. While most pollock are caught on jigs and teasers, they are also taken with bait, such as clams with entrails hanging off the hook or 1- by 3-inch strips of fish.

In inshore areas, pollock are particularly active around breakwaters and other structures during a moving tide. Early morning and evening produce the best results, but pollock can be caught throughout the day. Smaller inshore pollock are often pursued with lighter spinning outfits spooled with 12- to 15-pound test line. One-quarter- to 2-ounce lures such as streamers, leadheads, mackerel jigs, Kastmasters, and small plugs that resemble sand eels all catch fish. A small strip of squid or other bait added to a metal lure can increase the angler's success.

A pollock should be iced at capture to preserve its excellent taste and delicate texture. The nickname "Boston bluefish" reflects this species' appearance and fighting ability, not its culinary uses. Its light, flaky flesh can be substituted for cod or haddock in most recipes. Pollock can be poached, baked, broiled, grilled, or put into fish chowders. For an easily prepared meal, put a large pollock fillet into a baking dish greased with margarine and cover it with a can of undiluted cream of mushroom soup. Sprinkle with a little paprika and parsley. Bake at 400 degrees for 20 minutes or more, depending upon the thickness of the fillet. The fillet is ready to eat when it begins to flake easily. Serve the fish and sauce on a bed of rice, and enjoy a delicious meal.

Michael R. Ross and Laura A. Thorpe

Department of Forestry and Wildlife Management

University of Massachusetts

Robert C. Biagi

Cooperative Extension

University of Massachusetts

Supported by Federal Aid in Sport Fish Restoration Act, through the Massachusetts Division of Marine Fisheries, Department of Fisheries, Wildlife, and Environmental Law Enforcement, Executive Office of Environmental Affairs.

Produced by Cooperative Extension Communications Center. Liz Scott, design; Nancy Haver, Roy Lewando, illustration. University of Massachusetts, United States Department of Agriculture, and Massachusetts counties cooperating. Issued by E. Bruce MacDougall, Dean, in furtherance of the Acts of May 8 and fune 30, 1914. Cooperative Extension offers equal opportunity in programs and employment. When a product name is mentioned, no discrimination is implied against similar or equivalent products. CR60:12/87-10.11

This publication is part of the Marine Recreational Fisheries series, available from the Division of Marine Fisheries, 100 Cambridge Street, Boston, MA 02202. 


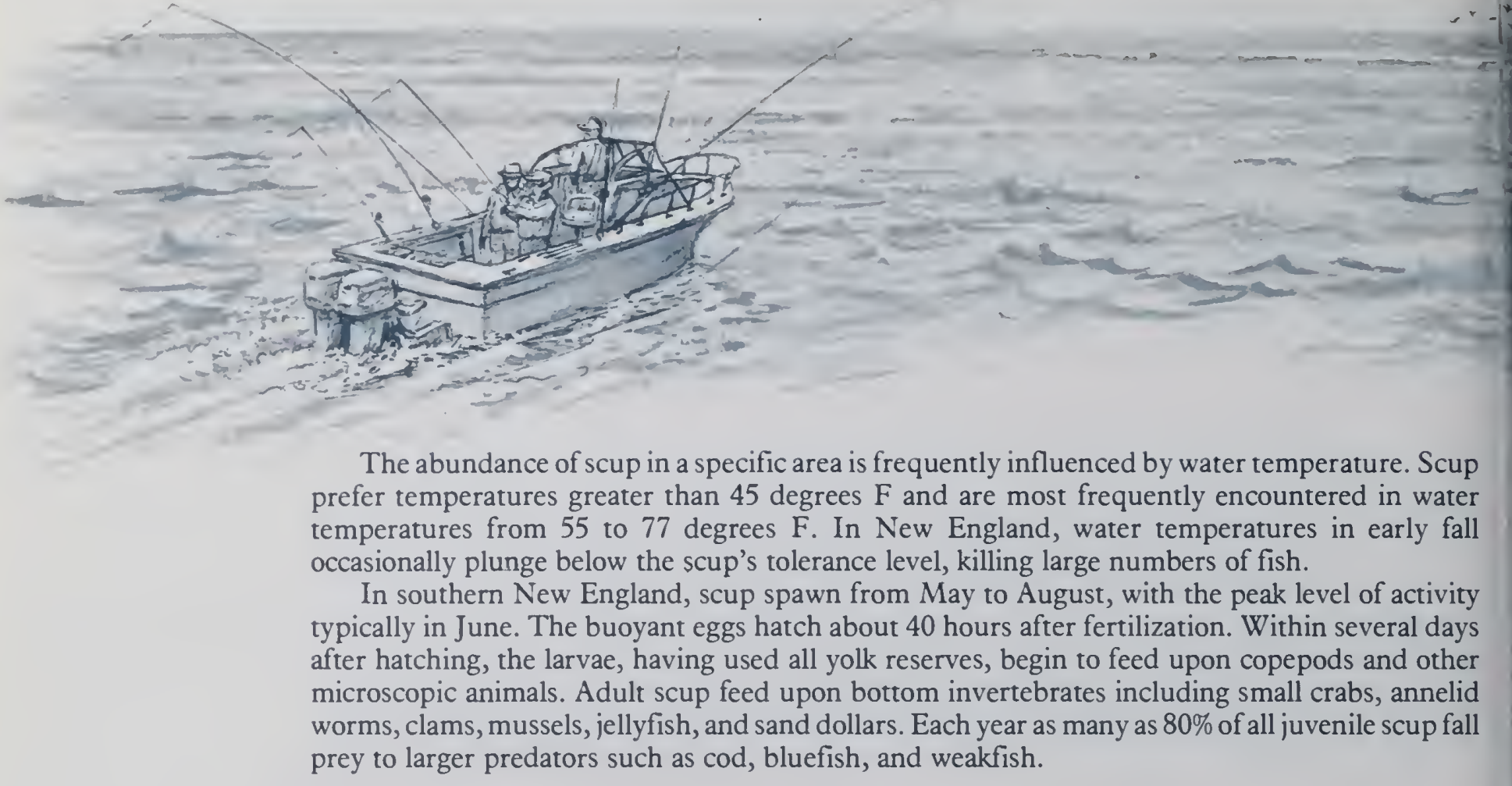

\section{Management}

$\mathrm{R}$

ecreational fishing constitutes a significant proportion of the total harvest of scup. From 1977 to 1985 , an average of $24 \%$ (ranging from $17 \%$ to $33 \%$ ) of the harvest of scup along the east coast was taken by anglers.

Scup populations on the east coast have displayed periodic cycles of abundance over the last twenty years, with any change in population density generally lasting for 2 to 4 years before being reversed. Commercial and recreational catches peaked in the 1950 s to 1960 s, declined markedly by the early 1970s, and recovered to relatively high levels before 1980. Much of the increase in harvest in the 1970s is attributed to an increase in fixed gear and otter trawl activity in the southern New England region. Harvest levels have steadily declined since 1981, with 1985 commercial landings $24 \%$ below the average for the previous 7-year period and the 1984-1985 recreational catch the lowest since 1972.

Scup are currently being harvested at the maximum level their populations can withstand. The Massachusetts Division of Marine Fisheries has established a minimum legal size limit for scup (7 inches in 1987) to protect this species from the longterm effects that any additional increase in harvest might engender.

\section{Angling and Handling Tips}

cup feed frantically and fight energetically when hooked, thereby providing angling enjoyment for the entire family. This little scrambler is especially fun for children, as a school of actively feeding scup typically provides non-stop fishing action.

Scup provide particularly exciting battles when anglers use either a medium-weight spinning or light-weight surf outfit carrying a 10 -to 20 -pound test line. Some anglers prefer jigging small lures, but the overwhelming majority prefer bait fishing. A typical rig includes the following. A bank sinker is tied to the end of the line. One to 3 snelled hooks (size \#1 to \#8) are then tied to loops 


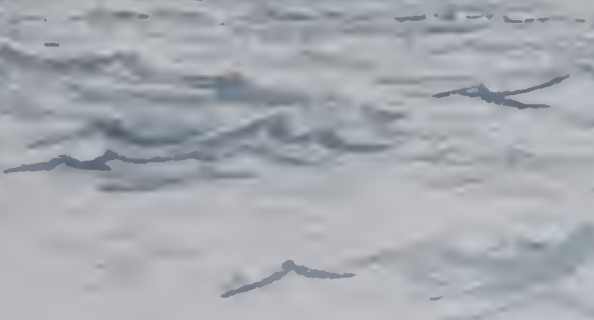

6 to 10 inches above the sinker. Sea worms, squid strips, and pieces of clam or fish work well as bait. Squid strips are favored because they last well through the frantic attacks a school of scup will make upon baited hooks.

Although scup are quick to grab a bait, they are difficult to hook. For greatest success anglers need to become adept at setting the hook as soon as the tip of the fishing rod shows the slightest dipping, or at lifting the baited hooks gently off the bottom to induce fish to strike sharply rather than allowing them to nibble at the bait. Upon finding a school of actively feeding scup, some anglers lower the bait to the bottom, count to five and set the hook, rather than risk having their bait stolen while waiting for the subtle nibble of this fish.

Scup do not spoil as quickly as many other fish, which must be immediately cleaned or placed in ice. Still, timely icing and cleaning is recom-

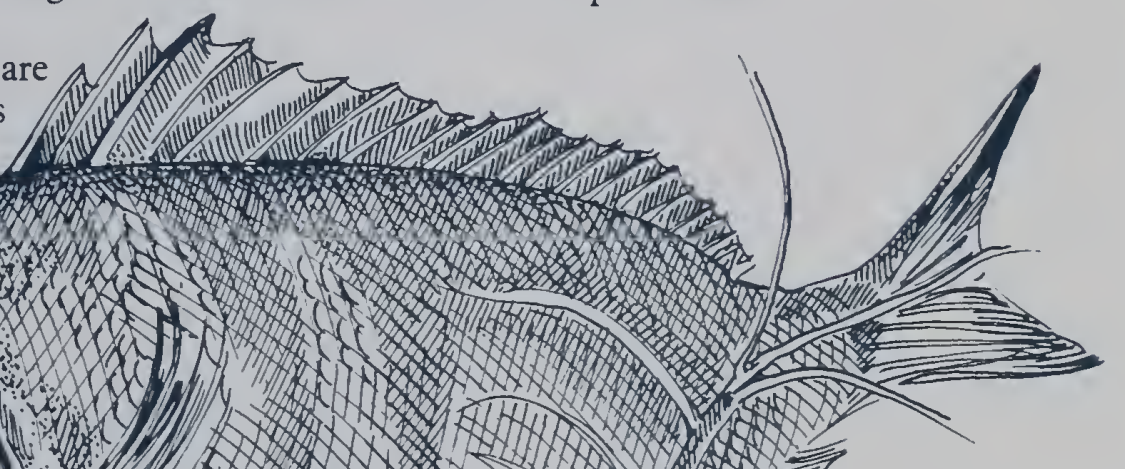
mended in order to enjoy the full sweetness of this species' flavor. Simple methods of preparation are best. Favored recipes include frying or poaching and serving with melted butter or margarine and a slice of lemon or lime. Large scup are delicious when lightly coated with butter, margarine, or mayonnaise and grilled over a charcoal or gas fire. Leaving the scaled skin on the fillets will help hold the flesh together when grilling.

Michael R. Ross and Laura A. Thorpe

Department of Forestry and Wildlife Management

University of Massachusetts

Robert C. Biagi

Cooperative Extension

University of Massachusetts 


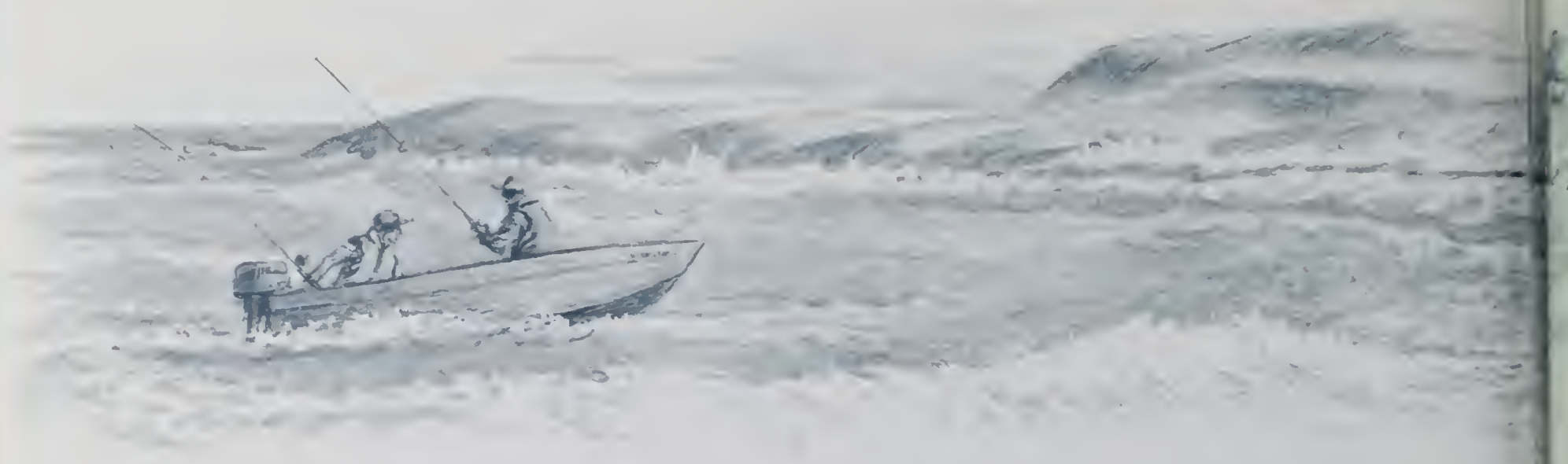

Supported by Federal Aid in Sport Fish Restoration Act, through the Massachusetts Division of Marine Fisheries, Department of Fisheries, Wildlife, and Environmental Law Enforcement, Executive Office of Environmental Affairs.

Produced by Cooperative Extension Communications Center. Liz Scott, design; Nancy Haver, Roy Lewando, illustration. University of Massachusetts, United States Department of Agriculture, and Massachusetts counties cooperating. Issued by E. Bruce MacDougall, Dean, in furtherance of the Acts of May 8 and fune 30, 1914. Cooperative Extension offers equal opportunity in programs and employment. W'hen a product name is mentioned, no discrimination is implied against similar or equivalent products. CR60:12/87-10M

This publication is part of the Marine Recreational Fisheries series, available from the Division of Marine Fisheries, 100 Cambridge Street, Boston, MA 02202. 


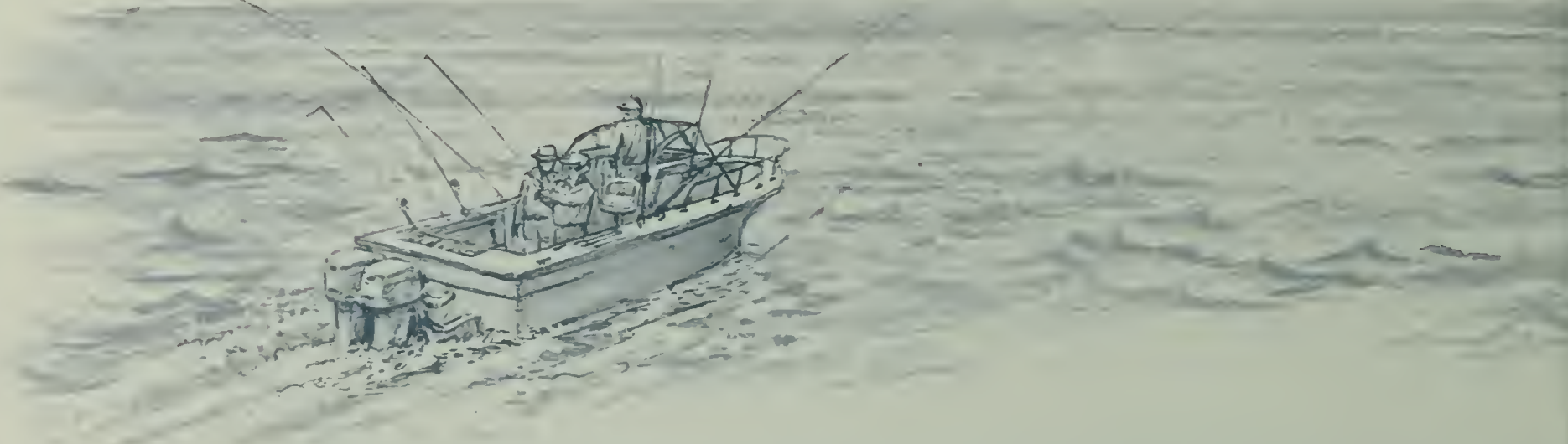

Makos migrate to northerly latitudes during the warm months of summer. As waters cool in the fall, they swim southward along the Continental Shelf to winter in the Caribbean.

Male sharks have two specialized copulatory organs, the claspers, which are derived from pelvic fins (B on diagram). These allow sperm to be passed into the reproductive tract of the female. After eggs are fertilized, they develop within the uteri of the female. Developing young are nourished largely by yolk reserves deposited around the egg cells before fertilization. During later stages of development, they may also feed upon unfertilized egg cells or uterine fluids. After about one year of embryological development, a female mako gives birth to one or several young, each measuring 24 to 31 inches in length. Shark offspring are generally much larger and more highly developed than are newly hatched young in species that reproduce by external fertilization. Thus, the prolonged period of internal incubation furnishes young sharks with a much higher probability of survival than is characteristic of the majority of fish species.

Makos feed heavily upon schools of smaller fish such as mackerel and herring, but also attack large fish such as the swordfish. In the southern New England region, bluefish can comprise up to $80 \%$ of this species' diet.

\section{Management}

I

n 1986, an estimated 2,322,000 sharks, excluding dogfish, were landed recreationally along the Atlantic and Gulf coasts of the United States. The middle Atlantic states landed the highest proportion at approximately 1,141,000 fish; 33,000 sharks were harvested along the northeast coast. The mako has been one of the most avidly sought shark species. It is pursued in private or charter boats 20 to 60 feet long that are powered by everything from outboards to large diesel engines.

Mako sharks are also harvested by commercial operations, taken either as by-catch by pelagic longline vessels pursuing tuna, or by a bottom longline fishery directed specifically toward makos. Shark bottom longline gear may be composed of up to 300 baited hooks strung along an 8-mile line, and pelagic (mid-water column) tuna longline gear may have up to 2,200 baited hooks spaced along a line up to 60 or 70 miles long.

A Preliminary Management Plan for Atlantic sharks was prepared in fall 1987 by the Regional Management Councils (established by the Magnuson Fishery Conservation and Management Act) in order to reduce the potentially conflicting interests of foreign and domestic fishermen, including recreational anglers. This plan sets an annual quota for foreign landings, identifies seasonal closures for regions off the Atlantic Coast, and establishes gear limitations (such as minimum hook sizes) for foreign vessels participating in the directed shark longline fishery. As of 1988 , no state regulations have been established to control harvest of this species in Massachusetts territorial waters. 


\section{.}

st:

sinter

\section{Angling and Handling Tips} investment in specialized equipment.

Most makos range from 50 to 300 pounds and can be landed with 30 - to 50 pound test dacron line. A strong wire leader that will resist cutting by the mako's sharp teeth and rough skin is a necessity. The mako prefers baits with a high oil content, such as bluefish and mackerel; however, it will strike at a variety of baits when attracted to them. Bait should be placed whole or in paired fillets on size $8 / 0$ to $14 / 0$ hooks.

A variety of tactics is used to attract sharks to the area of baited hooks. Sharks can be attracted from great distances by low frequency vibrations set up by sound waves in the water. Anglers pound or bang objects off the side of the boat or splash buckets in the water as a means of attracting sharks. A few go to extremes, such as playing music from waterproof speakers placed in the water.

Chumming is considered the most effective way to attract sharks. The simplest method is to periodically ladle a mixture of ground fish and water over the side of the boat, occasionally adding chunks of fish to the chum slick.

When a mako picks up the bait and starts swimming, line should be free-spooled before the hook is set. After a brief run, the hook should be set hard three or four times. Extreme care should be taken when the fish is ready to be landed. Once gaffed, a mako is capable of wrenching the gaff from the angler's grip or bending it out of shape. Never attempt to boat the mako prematurely; such action will result in a lost fish, destroyed gear, or possibly severe damage to the boat or angler before the fish is subdued. It is best for the novice shark fisherman to accompany someone experienced, so that shark fishing can be learned safely.

Although shark meat was long ago accepted as desirable table fare by many cultures, only recently has it been marketed under its own name in the United States. As other traditional seafoods, such as swordfish, have become less avail- 
able and more expensive, more people have been willing to substitute shark as a specialty fish item in their menu.

The blood and tissues of sharks contain unusually high amounts of urea, which must be drained to prevent the flesh from becoming unpalatable; thus, makos should be bled as soon as possible after capture. Careful immediate icing is also a necessity to prevent the flesh from building up an ammonia flavor. Mako steaks can be soaked in brine (use uniodized salt) and/or marinated in citrus juice prior to cooking.

Grilling mako is quick and simple. Marinate one-inch-thick steaks in orange juice and lemon slices for at least one hour. Remove from the marinade, pat dry and brush with mayonnaise or olive oil, and add some freshly ground pepper. Grill on a hot fire or broil four inches from heat for five minutes on a side and serve with a quartered lime.

Michael R. Ross and Laura A. Thorpe

Department of Forestry and Wildlife Management

University of Massachusetts

Robert C. Biagi

Cooperative Extension

University of Massachusetts

Supported by Federal Aid in Sport Fish Restoration Act, through the Massachusetts Division of Marine Fisheries, Department of Fisheries, W'ildlife, and Environmental Law Enforcement, Executive Office of Emironmental Affairs.

Produced by Cooperative Extension Communications Center. Liz Scott, design; Nancy Haver, Roy Lewando, illustration. University of Massachusetts, United States Department of Agriculture, and Massachusetts counties cooperating. Issued by E. Bruce MacDougall, Dean, in furtherance of the Acts of May 8 and June 30, 1914. Cooperative Extension offers equal opportunity in programs and employment. When a product name is mentioned, no discrimination is implied against similar or equivalent products. CR60:12/87-10.19

This publication is part of the Marine Recreational Fisheries series, available from the Division of Marine Fisheries, 100 Cambridge Street, Boston, MA 02202. 


\section{Marine Recreational Fisheries of Massachusetts}

\section{Tautog}

$\mathrm{T}$ he tautog (or "tog"), a popular inshore game fish, has ranked as high as fourth in recent the Atlantic coast from Nova Scotia to South Carolina, with the greatest number lying along inshore waters from southern Cape Cod to the Delaware Capes. It does not sustain a recreational fishery north of Massachusetts.

The tautog is a stout fish with a blunt nose and a thicklipped mouth that has large conical teeth in front and flat crushing teeth in back. The single dorsal fin (A on diagram) originates over the gill slit and runs back nearly to the tail. The anterior three-quarters of this fin possesses a series of stiff, sharp spines. The anal fin (B) has three spines, and the paired pelvic fins $(\mathrm{C})$ have one spine each.

The color of the tautog's dorsal area ranges from dark green to black, with these shades mottling a lighter background color on the

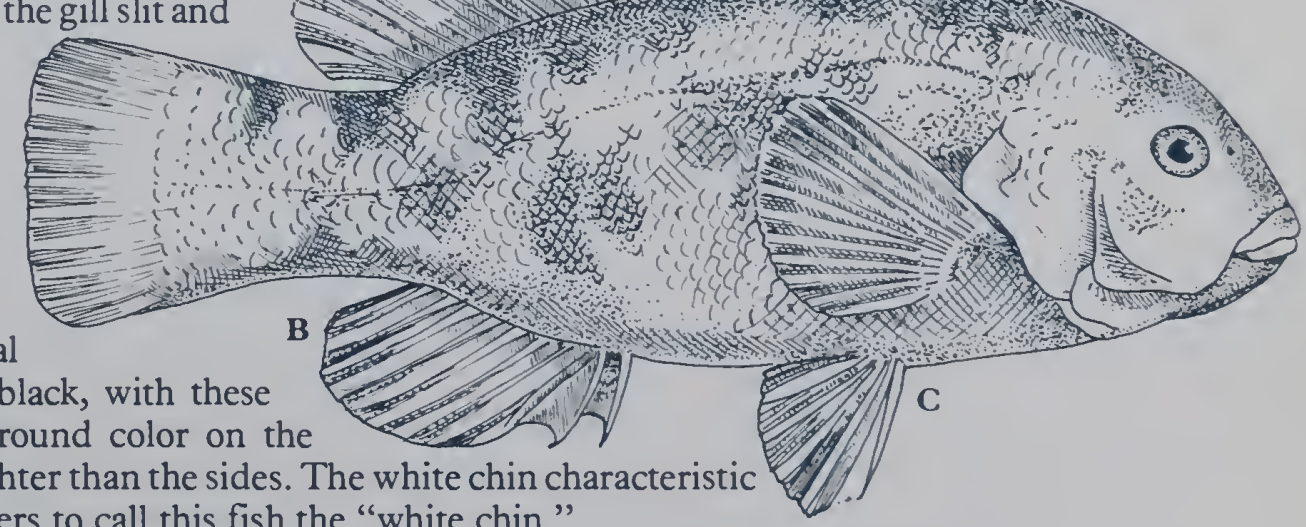
of large tautog has led many anglers to call this fish the "white chin."

Although capable of reaching relatively large sizes, tautog are very slow-growing. The largest tautog caught with hook-and-line in Massachusetts weighed 22 pounds 9 ounces. However, the average fish caught by anglers is 6 to 10 years old and weighs 2 to 4 pounds. The table below lists the average lengths and weights attained by male and female tautog at selected ages. Males typically grow faster and live longer than females. The maximum age for males appears to be about

\begin{tabular}{|ccccc|}
\hline $\begin{array}{c}\text { Length } \\
\text { in Inches }\end{array}$ & \multicolumn{2}{c}{ Weight } & \multicolumn{2}{c|}{ Age } \\
lbs. and ozs. & males & females \\
6 & 0 & 3 & 2 & 2 \\
10 & 0 & 9 & 4 & 4 \\
14 & 2 & 0 & 6 & 7 \\
17 & 3 & 7 & 9 & 9 to 11 \\
20 & 5 & 8 & 12 to 15 & $\begin{array}{c}13 \text { to } 20 \\
\text { no data } \\
\text { available }\end{array}$ \\
24 & 10 & 0 & 18 to 27 & \\
\hline
\end{tabular}
35 years.

Both sexes mature at 3 or 4 years of age. The fecundity (number of eggs produced in a spawning season) of females is directly related to their size and weight. Females 12 inches long and 1 pound in weight produce about 30,000 eggs, while females 20 inches long and 5 pounds produce about 196,000 eggs per season. 


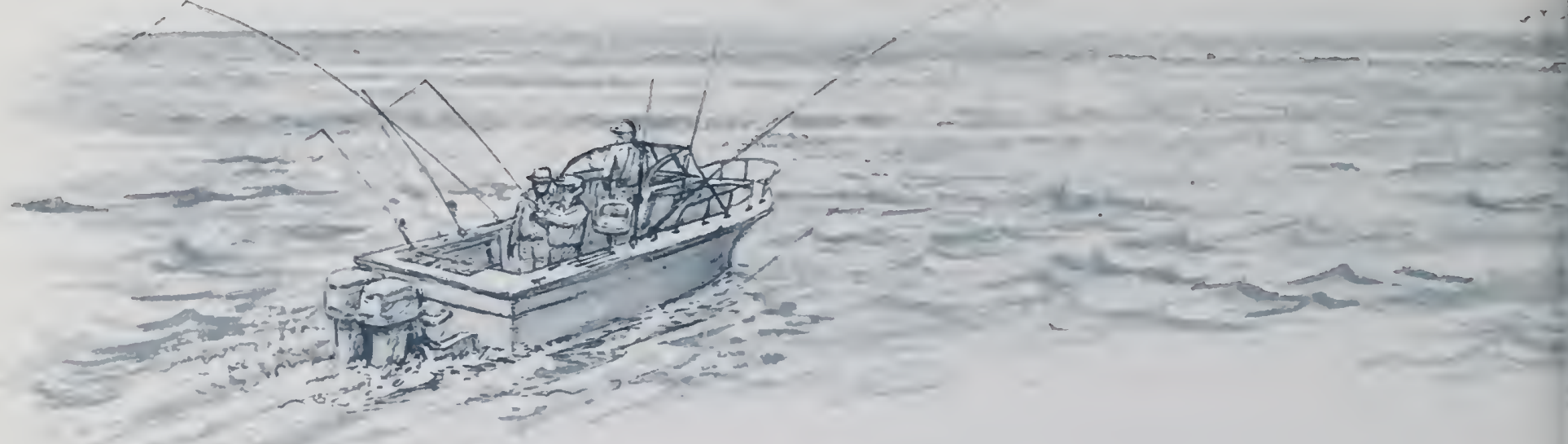

\section{Habits}

I

$\mathrm{n}$ the northern part of their range, tautog are typically encountered within several miles of shore in water less than 60 feet deep. More southern populations can be found somewhat farther offshore. Tautog frequently follow flood tides inshore to feed in the intertidal areas, and drop back to deeper waters with the following ebb tides.

Tautog are found in association with cover, hovering around steep, rocky shorelines or hiding near wrecks, wharf pilings, piers, jetties, mussel and oyster beds, and boulder-strewn bottoms. They generally stay within localized home ranges while feeding and resting. While on their summering grounds, tautog establish a "home site," a protected spot in which they rest every night. Small tautog do not venture far from their home site during the day, but adults range widely when feeding.

Tautog do not undertake seasonal migration, but tend to move inshore as water temperatures rise in spring, and overwinter in large groups offshore in waters 50 to 150 feet deep in areas where the bottom is covered with large boulders. Fish less than 10 inches long may remain in shallow estuaries throughout the winter. Some fish remain offshore all year, exhibiting no movement except when searching for food or cover.

In Massachusetts, tautog reproduce from May until August, with peak spawning activity occurring in June at water temperatures of 62 to 70 degrees F. Most spawning takes place inshore in areas dominated by eelgrass beds. Although they intermix in large groups for the rest of the year, tautog tend to remain in small, discrete groups during the spawning season. After reaching sexual maturity, many fish return to the same spawning area each year throughout their lives.

The fertilized eggs are buoyant, floating for about 2 days before hatching. Within 4 days after hatching, the larvae begin feeding on microscopic plankton.

Juvenile and adult tautog are exclusively daytime feeders, with feeding peaks at dawn and dusk. They are usually so inactive at night that divers can easily catch them by hand as they lie motionless on the bottom. Tautog feed upon shallow water invertebrates such as mussels, clams, crabs, sand dollars, amphipods, shrimp, small lobsters, and barnacles. Juveniles and adults living around shoreline ledges feed heavily on blue mussels; their flat grinding teeth are well-suited for crushing the hard shells of such animals.

\section{Management}

$\mathrm{T}$

autog population levels have been generally stable since colonial times. This species has historically had little market value, and thus has not been commercially exploited. However, in recent years the poundage taken by commercial fishermen has increased markedly. Between 1983 and 1986, the poundage of tautog landed by gear other than hook and line has increased nearly three times, as indicated in the figure. This increase in harvest, generally occurring throughout coastal areas of southern New England and New York, is due in part to an 
increase in the tautog's market value as other traditionally more valuable commercial species become less abundant and harder to catch. Slow-growing species such as the tautog can be reduced in abundance easily by exploitation. One of the first signs of overexploitation of such species is a

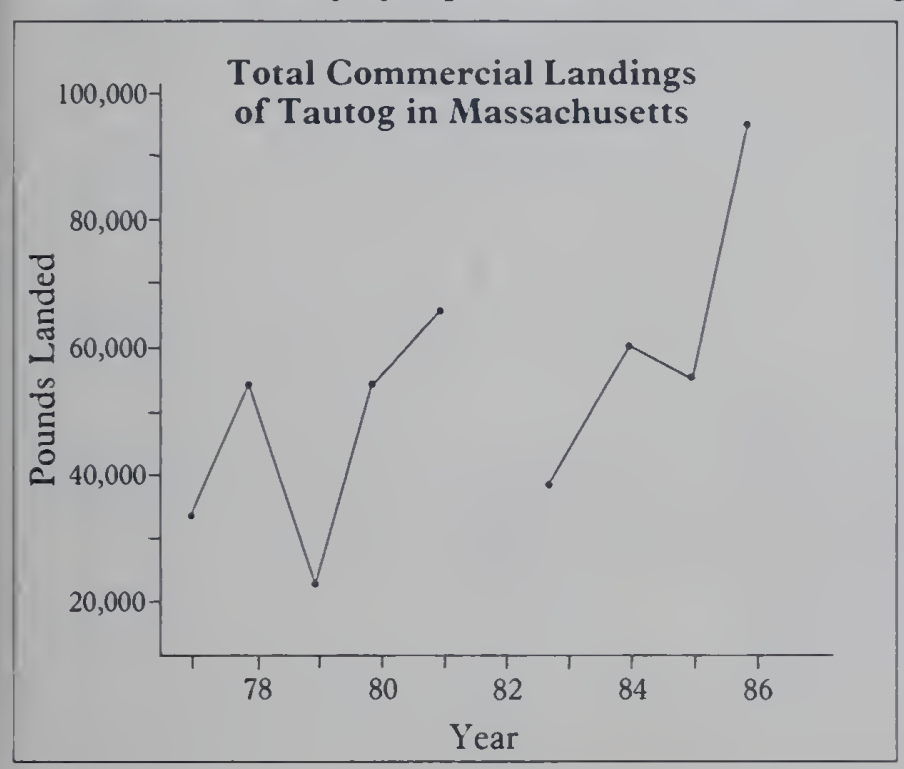
marked reduction in the average size of fish harvested; this phenomenon is currently being exhibited by tautog fisheries. Massachusetts is monitoring the effects of commercial and recreational harvests to determine whether regulations governing landings will be needed in future years.

\section{Angling and Handling Tips}

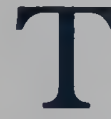

autog are hard-fighting, tough on tackle, and excellent on the table. Tog are one of the first species available to anglers in the spring and one of the last available in the fall. Anglers are particularly successful from April through May, and in early fall when tautog are concentrated in the greatest numbers along shorelines. While the best fishing is centered on Cape Cod, tautog can be caught all along the Massachusetts coast from Cape Ann to the South Shore.

\section{Tog are}

caught 

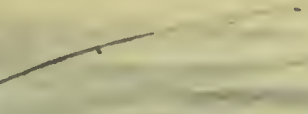

\section{Marine Recreational Fisheries of Massachusetts}

\section{Tomcod}

to Virginia. Its center of abundance extends from coastal Newfoundland to the New York bight

region. A typical inhabitant of brackish water, this fish is also found landlocked in several freshwater lakes of coastal Canada.

Like other members of the cod family such as the haddock, cod, and pollock, the tomcod has 3 dorsal fins (A on diagram) and 2 anal fins (B). The tomcod can be distinguished most easily from these other species by the presence of elongate rays (support elements) in its pelvic fins (C) and a rounded tail.

Tomcod are olive or brownish-green on the back and upper sides, paling to white or yellowish-gray on the belly. The back and sides are tinged with yellow and are darkly mottled. The dorsal fins and tail are the same color as the back, and the anal fins are olive or pale gray.

The tomcod can weigh up to $1 \frac{1 / 4}{4}$ pounds and measure 15 inches; however, most individuals weigh less than a pound and measure less than 12 inches in length. Although some tomcod reach 4 or 5 years of age, few exceed the age of 3 .

Both males and females reach sexual maturity by the end of their first year. The fecundity (number of eggs produced in a given season) of females increases with size and weight. Two- and 3-year-old females from the Weweantic River carried 6,000 to 30,000 eggs. In analyses of Canadian populations, the largest females (14 inches in length) carried as many as 65,780 eggs.

\section{Habits}

$\mathrm{T}$ he tomcod is a near-shore inhabitant along the Canadian and Gulf of Maine coasts; south of Cape Cod it can be found somewhat farther from the coastline, although never occurring more than 1 mile from shore, nor in water deeper than 20 feet. Although tomcod are sometimes caught by anglers on open, exposed shores, most fish prefer shallow, protected bays and the mouths of rivers with expansive eelgrass beds. 


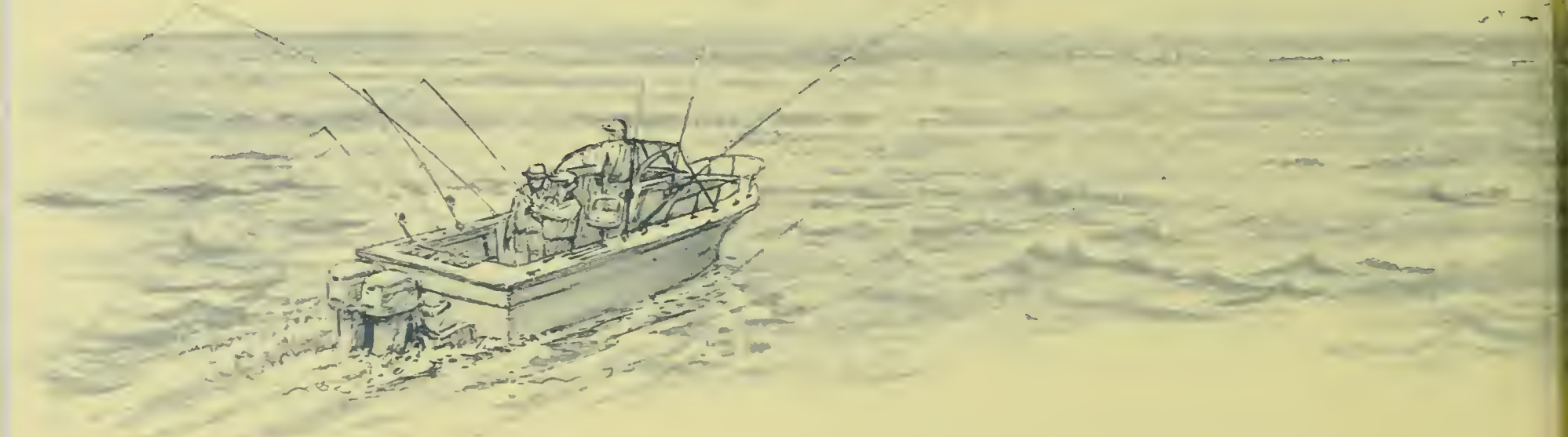

Tomcod are called "frostfish" because they appear in very shallow water during the fall and winter. They exhibit no migratory pattern in the Gulf of Maine, but south of Cape Cod they tend to move into deeper waters in the spring and summer and return to shallow bays and estuaries in the late fall and winter. Tomcod are extremely tolerant of the sudden changes in temperature and salinity that are characteristic of life in shallow estuarine waters.

Tomcod reproduce in brackish or freshwater areas of estuaries and streams from November to early February, with peak spawning activity occurring from December to early January. The eggs are demersal (sink to the bottom) and adhere in clumps to seaweeds, rocks, or other projections of the substrate. The eggs hatch after 22 to 35 days, depending upon water temperature; eggs in warmer waters hatch more rapidly than those in colder waters. Within several days after hatching, larvae begin to feed on microscopic invertebrates.

Larvae normally drift downstream into the estuary, where they stay throughout their first summer. Juvenile tomcod are found in greatest numbers in beds of eel grass, which provide them with shelter and food resources. While in estuaries and quiet bays from October to May, adult tomcod exhibit activity patterns keyed to tidal fluctuations. During flood tides they actively feed over subtidal flats, while during ebb tides they move to deeper channels nearby.

Tomcod eat many types of fish and invertebrates. Shrimp and amphipods make up the greatest portion of their diet. They also eat small molluscs, squid, marine worms, and small fish such as smelt, sticklebacks, alewives, shad, herring, cunners, mummichogs, sand lance and even young striped bass. Mainly bottom feeders, tomcod use the chin barbel and long rays of the pelvic fins to detect food on the substrate over which they are swimming.

\section{Management}

$\mathrm{T}$ he tomcod supported a very modest inshore commercial fishery through the early 20th Century. In 1929, about 28,000 pounds of tomcod were harvested and marketed in Massachusetts, Maine, and the Canadian shores of the Gulf of Maine. In Massachusetts, the commercial harvest was largely a hook-and-line fishery north, and a trap-and-weir fishery south of Plymouth. By 1942, the commercial fishery had generally disappeared from Massachusetts, but persisted in Maine and Nova Scotia, where 27,500 pounds were reported landed. No commercial harvest of this species has occurred since the early 1950 s.

The recreational fishery for tomcod is most active in the winter and early spring in estuaries and in the mouths of coastal streams. This species is frequently caught incidentally during the active recreational smelt fishery that is conducted along the Massachusetts coast. As of 1988, there are no restrictions on recreational harvest of the tomcod in Massachusetts. 


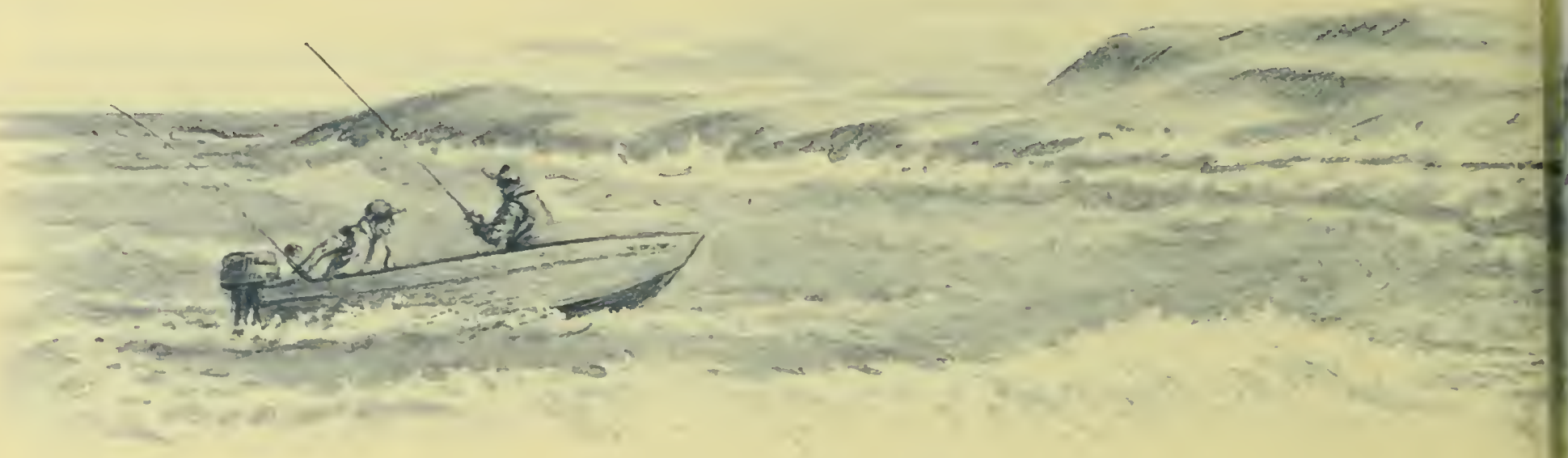

Supported by Federal Aid in Sport Fish Restoration Act, through the Massachusetts Division of Marine Fisheries, Department of Fisheries, Wildlife, and Environmental Law Enforcement, Executive Office of Environmental Affairs.

Produced by Cooperative Extension Communications Center. Liz Scott, design; Nancy Haver, Roy Lewando, illustration. University of Massachusetts, United States Department of Agriculture, and Massachusetts counties cooperating. Issued by E. Bruce MacDougall, Dean, in furtherance of the Acts of May 8 and fune 30, 1914. Cooperative Extension offers equal opportunity in programs and employment. When a product name is mentioned, no discrimination is implied against similar or equivalent products. CR60:12/87-10M

This publication is part of the Marine Recreational Fisheries series, available from the Division of Marine Fisheries, 100 Cambridge Street, Boston, MA 02202 . 


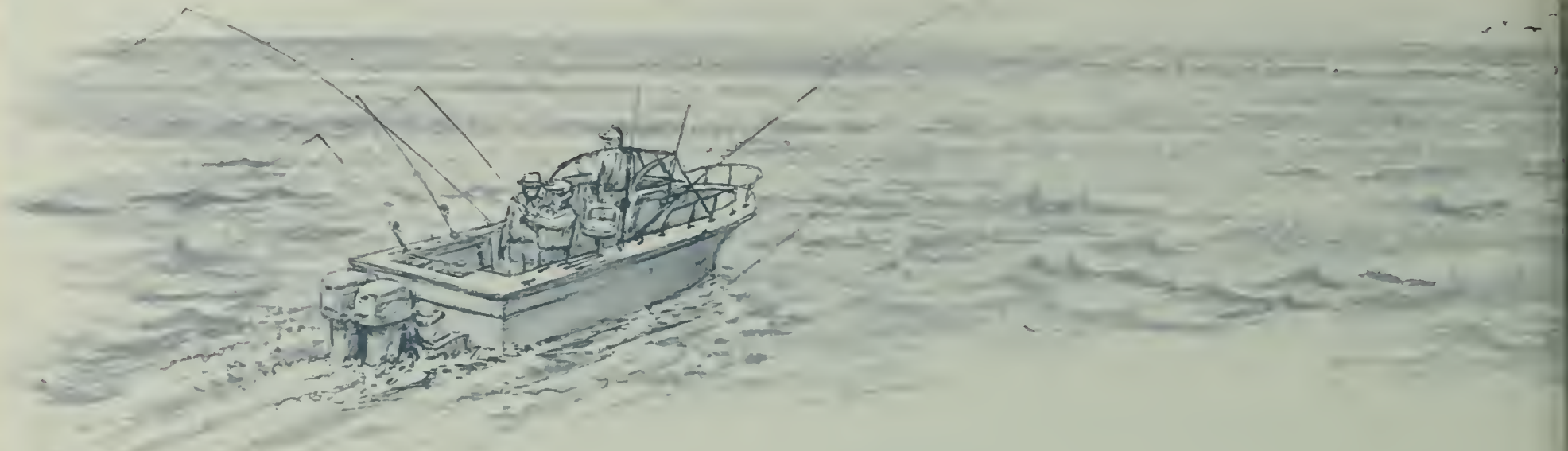

\section{Habits}

$\mathrm{B}$ luefin tuna travel both in schools and individually in inshore and offshore areas. They rarely occur more than 300 feet below the surface and are occasionally sighted swimming at the surface with their dorsal fins exposed above the water.

Bluefins follow extensive migratory routes within the Atlantic Ocean. Larger fish can tolerate waters as low as 50 to 54 degrees F, but smaller fish stay in areas where temperatures do not fall below 60 degrees F. Thus, giant tuna appear in New England waters by the end of June, having moved northward along the Atlantic Coast from Florida, while smaller fish do not typically arrive in our region until the late summer and fall. Reproduction takes place in the Straits of Florida from May to early June, before this species' northward migration.

Unlike most fish whose body temperatures match the temperatures of the surrounding water, tuna have the ability to regulate their internal body temperatures. This remarkable adaptation allows bluefin tuna to maintain body temperatures within a 5 degree $F$ limit when exposed to waters with as much as a 30 degree $\mathrm{F}$ range. This temperature control helps tuna maintain very high swimming speeds over prolonged periods of time. Bluefin tuna are noted open-water predators, chasing and feeding upon schooling species such as herring, mackerel, silver hake, and squid.

\section{Management}

A lthough historically a valued food fish in the Mediterranean and the West Coast of the U.S., until this century bluefin were considered little more than a nuisance along the East Coast of North America. Landings along the East Coast have increased dramatically as markets have developed since the turn of the century. For example, annual landings for the coasts of Maine and Massachusetts increased from less than 100,000 to nearly 2,000,000 pounds between 1919 and 1948. Over 6,250,000 pounds were landed in Massachusetts alone in 1975. Consistently increasing fishing pressure along the entire East Coast during the past several decades has significantly reduced the bluefin tuna resource. The value of bluefin tuna in the Japanese market has been a major driving force in this recent period of intensive exploitation.

The range of this highly migratory species extends well beyond U.S. territorial waters. The Magnuson Fishery Management and Conservation Act of 1976 (the "220-mile limit law") specifically excludes the United States from having sole management responsibility for tuna resources. The International Commission for the Conservation of Atlantic Tunas (ICCAT) recommends catch quotas for the bluefin tuna; these quotas are meant to maintain the bluefin resource at levels that will sustain future maximum harvests. Quotas are then allocated to nations participating in this fishery (the United States, Canada, and Japan). Under this allocation system, the United States has received approximately $52 \%$ of the total allowable annual harvest from 1982 
to 1987. The National Oceanic and Atmospheric Administration (NOAA) is responsible for regulating harvests by U.S. citizens and their vessels. The allocation to the United States is presently divided among 5 categories of fisheries:

1. a limited-entry purse seine fishery,

2. a harpoon fishery,

3. a general fishery including hook and line, hand line, and harpoon vessels,
4. an incidental catch fishery where bluefin are landed by vessels fishing for other species or other size classes of bluefin, and

5. an angling fishery for small fish.

Under this system, no one can participate in more than one category. Fishing within any category may be regulated by closed seasons, size and number limitations, and/or gear restrictions.

Once allocations intended for a particular category are met, the fishery for that category is closed for the year. Within a season, the Assistant Administrator for Fisheries

(NOAA) can adjust allotments by drawing on a portion of the total allocation that has been held in reserve.

\section{Angling and Handling Tips}

$\mathrm{T}$ he bluefin tuna (or "horse mackerel," as it was once called) is the ultimate big-game fish. It is more than a greatly desired trophy; it is also revered as a food species. Many anglers are willing to endure the hours of fishing typically necessary to hook into a bluefin in order to land one of these magnificent fish.

Bluefin are pursued largely from private and charter boats. The greatest success is achieved in areas of pronounced drop-offs and deep trenches adjacent to shallower waters.

Many anglers prefer the stand-up tuna rods and a $4 / 0$ to $6 / 0$ reel spooled with 30 to 80 -pound test dacron line. These rods are shorter and easier to use than are trolling rods. A variety of artificial 


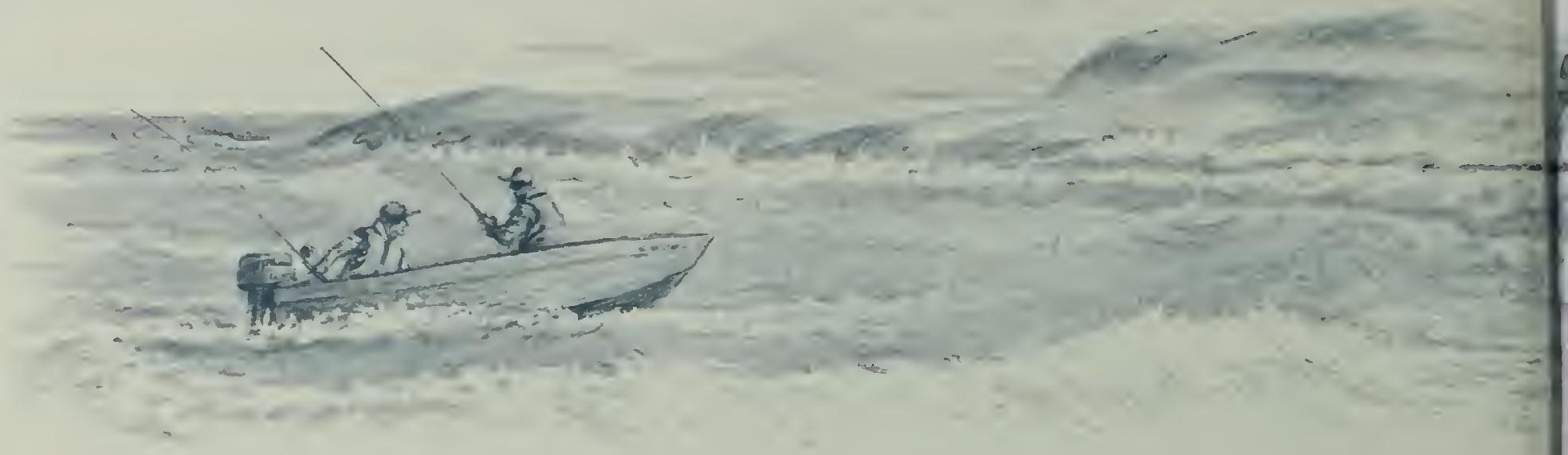

lures including diamond jigs, spoons, leadhead tuna feathers, 6-inch plastic squids, multi-squid rigs, daisy chains, and Kona or jet heads can be used. Live bait fishing is often accomplished by chunking. This method consists of first dropping chum and pieces of fish overboard at frequent intervals. After a few minutes, whole fish such as butterfish are placed on a $4 / 0$ to $8 / 0$ hook and dropped overboard into the "chum slick."

Giant fish are rarely retained for home consumption due to their extremely high value in Japanese markets. However, anglers often retain small school tuna for the table. Once landed, tuna need immediate attention if their light flavor is to be fully retained. Tuna should be bled immediately upon capture. Start by making a cut to the backbone just forward of the tail. Next, cut about two inches into the flesh under the pectoral fin. Gut and chill the fish as soon as possible. Later the tuna can be filleted, cut into steaks, and rinsed to flush out any remaining blood.

The Japanese prefer raw tuna prepared as sushi. However, the American palate typically prefers cooked tuna. Tuna can be pressure cooked, broiled, baked, and grilled as a kabob or as steaks covered with mayonnaise. Many people enjoy braising tuna. For this, tuna steaks should be soaked in cold water for an hour, patted dry, dusted with flour, and sautéed in butter or olive oil. After 10 minutes add pepper, parsley, seasoning of choice, and one cup of red or white wine. The tuna should be basted with the liquid, and cooked until the sauce is reduced by about one half.

Michael R. Ross and Laura A. Thorpe

Department of Forestry and Wildlife Management

University of Massachusetts

Robert C. Biagi

Cooperative Extension

University of Massachusetts

Supported by Federal Aid in Sport Fish Restoration Act, through the Massachusetrs Division of Marine Fisheries, Department of Fisheries, Wildlife, and Environmental Law Enforcement, Executive Office of Environmental Affairs.

Produced by Cooperative Extension Communications Center. Liz Scott, design; Nancy Haver, Roy Lewando, illustration. Unizersity of Massachusetts, United States Department of Agriculture, and Massachusetts counties cooperating. Issued by E. Bruce MacDougall, Dean, in furtherance of the Acts of May 8 and June 30, 1914. Cooperative Extension offers equal opportunity in programs and employment. W'hen a product name is mentioned, no discrimination is implied against similar or equivalent products. CR60:12/87-10.M

This publication is part of the Marine Recreational Fisheries series, available from the Division of Marine Fisheries, 100 Cambridge Sireet, Boston, MA 02202. 


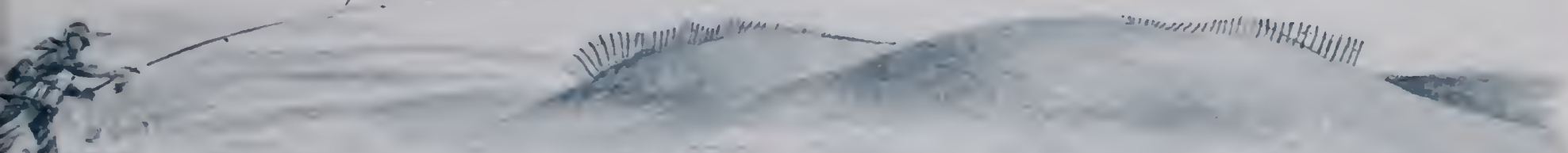

\section{Marine Recreational Fisheries of Massachusetts}

$$
\text { Weakfish }
$$

$\mathrm{T}$ he weakfish, also called the squeteague or gray sea trout, ranges from southern Florida north to Massachusetts Bay and occasionally to the waters off Nova Scotia. Abundant from the Virginia coast to the New Jersey shoreline, it occurs only as a summertime transientin Massachusetts waters. Its occurrence north of Cape Cod is too spotty to sustain a recreational fishery.

The weakfish is a streamlined species, the body being about four times as long as it is deep. Its head, about $1 / 3$ the length of its body, has a pointed snout and large mouth. The upper jaw is equipped with two large canine teeth and is shorter than the lower jaw, which projects noticeably beyond it. There are two separate dorsal fins (A on diagram). The anterior dorsal is triangular in shape and possesses a series of spines; the posterior dorsal is about three times the length of the anterior. The anal fin (B) is less than $1 / 2$ as long as the posterior dorsal. The tail is broad and slightly concave in outline.

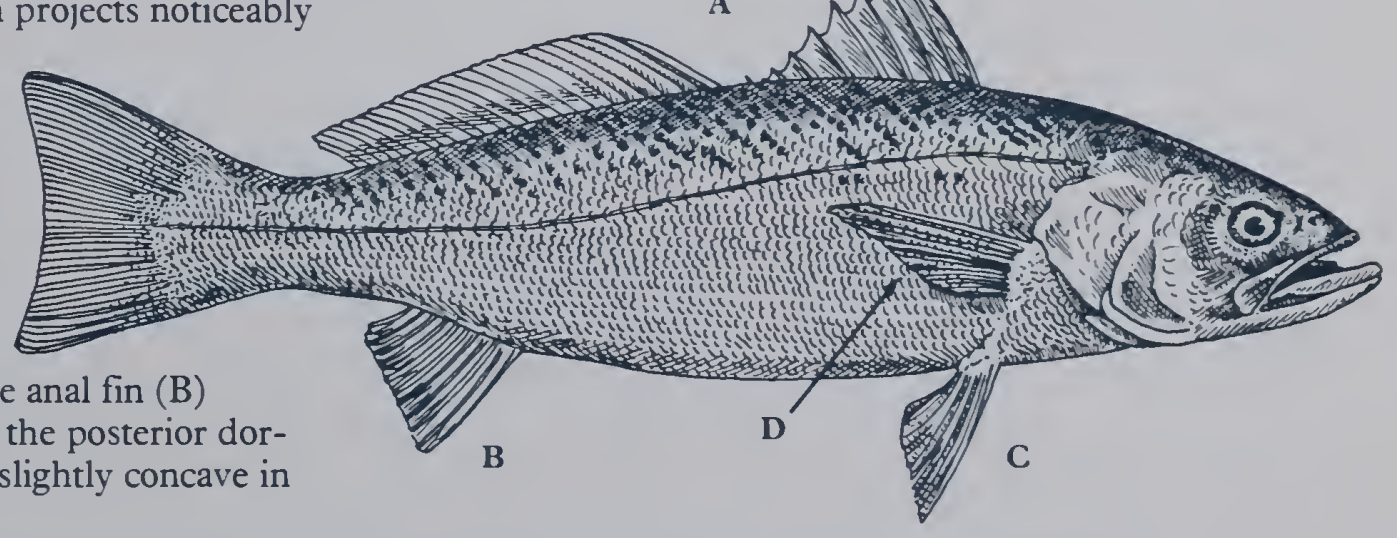

Weakfish are dark green or olive above, and blazed with purple, blue, and gold on the back and sides. Vertical rows of small dark spots occur on either side of the body. The belly is white. The dorsal fins and tail are dark, the pelvic (C) and anal fins are yellow, and the pectoral fins (D) are olive, marked with yellow near the base.

The largest weakfish landed by a recreational angler in Massachusetts weighed 18 pounds 12 ounces. However, most weigh less than 6 pounds. Although avidly pursued as a sport fish, the relatively slow-growing weakfish is at least several years old before it is large enough to be viewed as a "keeper" by many anglers. Specimens that exceed 2 feet in length are at least 10 years old. The adjoining table lists average lengths and weight ranges for weakfish up to the age of 6 years.

Both sexes become sexually mature at 3 to 4 years of age. The fecundity (number of eggs

\begin{tabular}{|ccc|}
\hline Age & Length in Inches & Weight in Lbs. \\
1 & 7.5 & less than 0.5 \\
2 & 10.4 & less than 0.5 \\
3 & 12.2 & 0.7 to 1.0 \\
4 & 14.8 & 1.0 to 1.5 \\
5 & 17.1 & 1.3 to 1.8 \\
6 & 18.9 & 1.7 to 2.5 \\
\hline
\end{tabular}
produced in a season) of females increases with age and size. An 11 inch female produces about 260,000 eggs, while a 22 inch female produces about $1,700,000$ eggs in a given spawning season. 


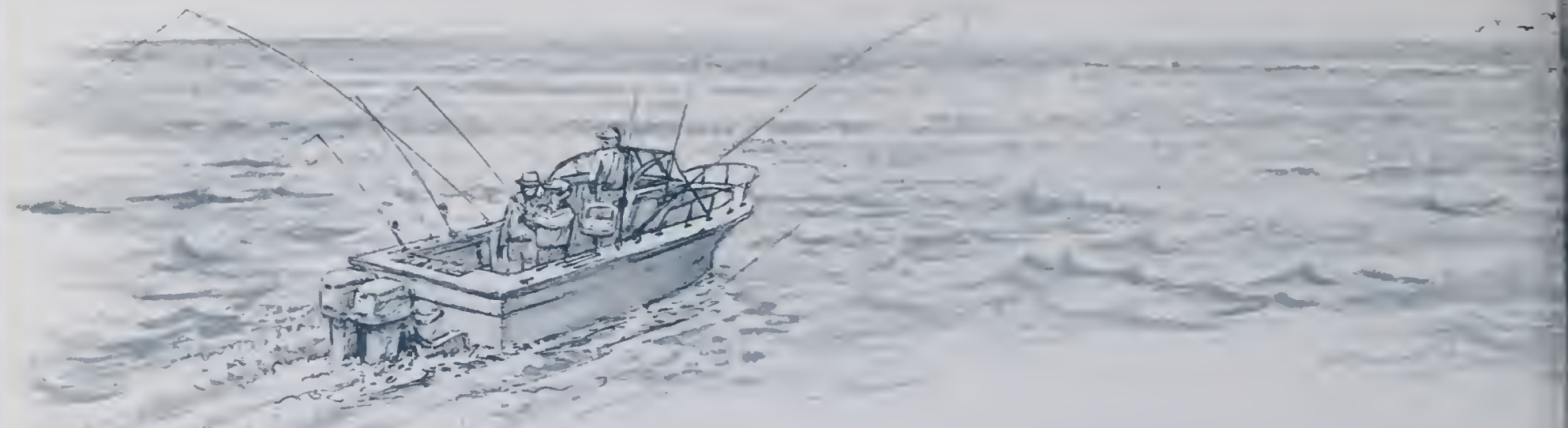

\section{Habits}

$\mathrm{T}$

he weakfish, although a frequent summer visitor to Cape Cod waters, is only occasionally

found in Massachusetts Bay. This species generally appears in southern Massachusetts in May and leaves by October. Some fish move offshore to deeper, warmer waters in the winter, but many are believed to migrate offshore and southward during this time of the year. Weakfish tend to move about in schools of similar-sized individuals. Evidence from Delaware Bay suggests that in the summer at least some of these schools are made up mostly of individuals of a single sex.

During the summer, weakfish inhabit inshore areas such as open sandy shorelines, bays and estuaries, and even salt marsh creeks. They typically occur in water less than 30 feet deep. Weakfish usually move about near the surface, although they also feed off the substrate in estuaries and the surf of the open coast.

This species reproduces in the mid-Atlantic region from May to October. Spawning takes place at night in estuaries and inshore areas. In years of high population abundance, weakfish may spawn as far north as Woods Hole or even in Massachusetts Bay.

The buoyant eggs hatch 36 to 48 hours after fertilization. Initially, the larvae swim within the water column, feeding upon microscopic plankton. When the larvae reach about 0.4 inches, they move to the bottom of muddy creeks and coves.

Juvenile weakfish feed heavily upon small crustaceans, particularly shrimp. Adults occasionally feed upon invertebrates such as crabs, shrimp, and squid. However, fish such as sand lance, silversides, scup, mackerel, butterfish, and particularly juvenile menhaden constitute the major portion of their diet.

\section{Management}

$\mathrm{H}$ istorically, the abundance of weakfish along the southern New England coast has fluctuated greatly, and this species occurs north of the southern shore of Cape Cod only when its abundance peaks in the southern New England region.

Although supporting only a modest fishery in New England, the weakfish is avidly pursued throughout the mid-Atlantic states. An estimated 11,106,000 fish were recreationally harvested in the mid-Atlantic region in 1986, which ranked this species sixth among all recreational species of that region.

As of spring 1988, there is no federal management plan overseeing the harvest of the weakfish, although the Mid-Atlantic Fishery Management Council plans to develop a management strategy in coming years. Since this species occurs only in modest numbers in Massachusetts' waters, management of its fishery here would likely have little impact on its coastwide abundance, or its continued occurrence in this state. Thus, the Massachusetts Division of Marine Fisheries has not established any regulations governing this species' harvest in our inshore waters. However, as coastwide management plans are developed in the future, Massachusetts might establish regulations as part of a multi-state effort in managing this resource. 

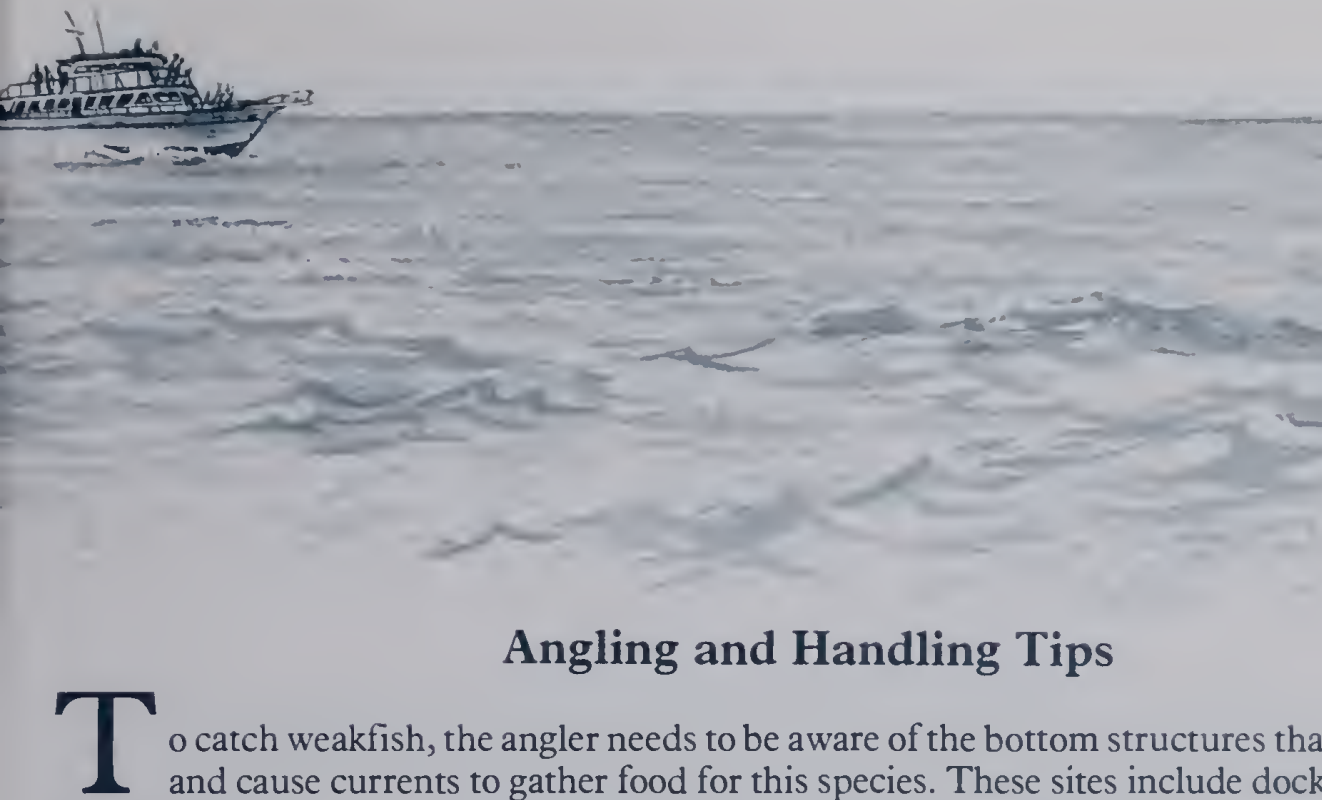

\section{Angling and Handling Tips}

o catch weakfish, the angler needs to be aware of the bottom structures that provide cover and cause currents to gather food for this species. These sites include docks, breakwaters, rises in the bottom contour (such as sand bars), rocks that produce "rips" of water, deep water drop-offs, and channels.

Typical gear includes a light- to medium-spinning outfit with a smooth drag and 8 to 15-pound test line. Weakfish cannot be "horsed in" with a heavy line because hooks will tear away from their soft mouths, hence the name "weakfish."

Artificial lures are most effective in the spring and fall. Weakfish strike at a variety of lures, including bright plastic shrimp, worms, bucktails, yellow leadheads, twisters, tubes, jigs, metal lures, and sand eel imitations.

Anglers generally find baits more successful than lures in the heat of the summer. Weakfish can be taken on a variety of baits including shrimp, seaworms, bunker, tinker mackerel, eels, strips of squid, and sometimes snapper blues. Live baits on a $6 / 0$ hook with a strong leader often work best for big weakfish. Many anglers will use strips of bait on a standard 2-hook bottom rig with 2/0 or 3/0 hooks, up to 2 feet of monofilament leader, and a sinker (flat or round types for bottom-fishing in calmer water, pyramid for fishing in surf).

The greatest success in landing weakfish is gained by anglers who show patience. The bail of the reel should be open to allow the weakfish to run with the bait after picking it up. When the fish stops running to swallow its catch, count to ten and set the hook, which by that time should be deep into its throat. Patient retrieval of line is necessary to prevent the hook from tearing away if the fish is hooked in the mouth.

The flesh of weakfish, white with a reddish mid-stripe, has a mild, almost sweet, flavor. "On-the-spot" icing is necessary to preserve its delicate flavor and texture.

Weakfish can be prepared in a variety of ways. One popular approach is to dip weakfish in milk, dust with flour, and sauté in butter or margarine for five minutes, turning once. Weakfish can be

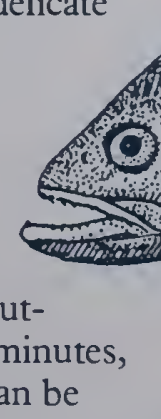


steamed in broth, or broiled, until the meat flakes; then served with lemon. A popular method in more southern areas is to stuff weakfish with crabmeat, wrap the fish in aluminum foil, and bake over hot coals on the grill for 10 to 15 minutes.

Michael R. Ross and Laura A. Thorpe

Department of Forestry and Wildlife Management

University of Massachusetts

Robert C. Biagi

Cooperative Extension

University of Massachusetts

Supported by Federal Aid in Sport Fish Restoration Act, through the Massachusetts Division of Marine Fisheries, Department of Fisheries, Wildlife, and Environmental Law Enforcement, Executive Office of Environmental Affairs.

Produced by Cooperative Extension Communications Center. Liz Scott, design; Nancy Haver, Roy Lewando, illustration. University of Massachusetts, United States Department of Agriculture, and Massachusetts counties cooperating. Issued by E. Bruce MacDougall, Dean, in furtherance of the Acts of May 8 and June 30, 1914. Cooperative Extension offers equal opportunity in programs and employment. When a product name is mentioned, no discrimination is implied against similar or equivalent products. CR60:12/87-10:M

This publication is part of the Marine Recreational Fisheries series, available from the Division of Marine Fisheries, 100 Cambridge Street, Boston, MA 02202. 
Q35. UM4.2:M34/Wndow.

University of Massachusetts/Cooperative Extension - Massachusetts Division of Marine Fisheries
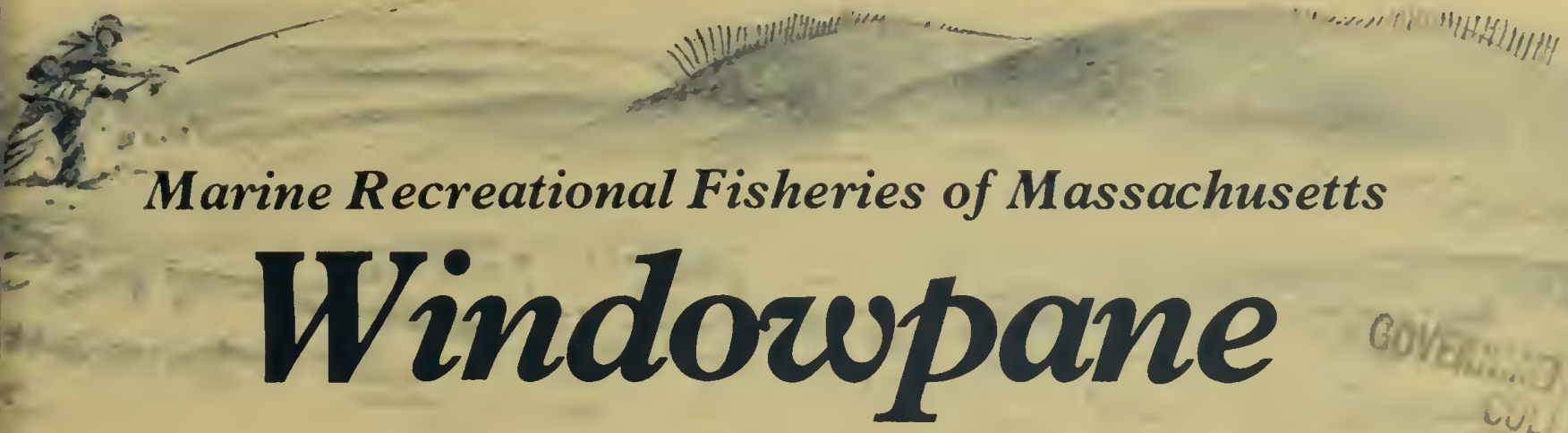

\section{Marine Recreational Fisheries of Massachusetts}

\section{Windowpane}

$\mathrm{T}$ he windowpane flounder, or sand flounder, a common species in the shallows of Massachusetts bays and out to Georges Bank, is native to the eastern coast of the United States from Maine to Florida. It is most abundant south of Cape Cod, and is abundant only in specific areas north of the Cape.

Like other flatfish, windowpane flounders are laterally flattened and have both eyes located on the upper side of the body. After hatching, larval flounders begin their lives with an eye on either side of the head. However, as the larvae mature, one of the eyes migrates to the other side of the head, and the body becomes markedly flattened. Unlike most bottom fish, which rest on their bellies, flounders are able to lie on one side with both eyes facing upward. Windowpane flounders are called lefthanded because both eyes are on the upper surface when the fish is pointing to the left.

Windowpane flounders are nearly circular in shape and are so thin that they appear translucent when held up to light. The tail is rounded at its outer margin. The pelvic fins ( $A$ on diagram) are broad-based and appear nearly continuous with the anal fin (B).

The first several rays of the windowpane's dorsal fin (C) are branched and unconnected by membrane, giving this fin a fringed appearance near the head. This characteristic separates the windowpane from all other northwest Atlantic flatfish.

The windowpane varies less in color than do most shallow water flounders. Generally, it is pale brown or olive green and mottled with irregularly-shaped small brown spots. The anal fin, dorsal

\begin{tabular}{|cc|}
\hline Age & Length in Inches \\
1 & \multicolumn{2}{c|}{ up to 7.1} \\
2 & \multicolumn{2}{c|}{7.9 to 11.4} \\
4 & males $11.6 \quad$ females 12.4 \\
6 & males $12.4 \quad$ females 13.6 \\
\hline
\end{tabular}

fin, and tail match the body color. The blind side is white.

The maximum size of windowpane flounders is about 18 inches in length and 2 pounds in weight. Fish of 14 inches weigh about 1 pound. The young grow rapidly during their first several years of life, after which growth slows markedly. Females are 


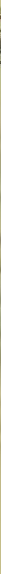

usually larger than males after the age of 3 years. Both sexes become sexually mature by 3 or 4 years of age. The preceding table lists typical sizes of windowpane at several different ages.

\section{Habits}

W indow pane flounders live in shallow water on the sandy bottom, hence the name "sand flounder." They occur from the intertidal zone to depths of nearly 150 feet in the northern portion of their range, but can be found at depths up to 2,000 feet in more southern areas. The windowpane is typically a year-round resident from southern New England northward. Individual fish may wander considerable distances along the coast, causing frequent intermingling among local populations. South of Cape Cod, these flounders tend to aggregate in shallow water in summer and early fall, and move more offshore in winter and spring. Windowpane can tolerate temperatures from 32 to 77 degrees F. However, this species' distribution is limited to areas where summer water temperatures exceed 55 degrees $\mathrm{F}$.

Windowpane flounders reproduce from spring to late summer in our region. Principal spawning grounds range from Chesapeake Bay to Cape Cod, and spawning takes place in water less than 120 feet deep. Estuaries serve as critical spawning habitat north of the New York Bight, but seem less important to the south.

The eggs are buoyant, floating near the surface for about 8 days before hatching. Larvae usually occur in water at depths of 65 to 131 feet. When they metamorphose to flatfish (before they reach $1 / 2$ inch in length), they move to the bottom, eventually descending to deeper waters as they mature.

Adults analyzed from Long Island Sound fed mostly upon species of shrimp, with small fish occurring only infrequently in their diet. Specimens from North Carolina contained fish as well as crabs and shrimp, and fish analyzed from Woods Hole had eaten small hake, herring, sand lance, and silversides. Various small invertebrates such as annelid worms, squids, and small molluscs also have been found in windowpane stomachs.

\section{Management}

$\mathrm{H}$ istorically, the windowpane had little commercial, and modest recreational, value. Its small, thin body does not produce as desirable a fillet as other, larger bodied flatfish. A commercial market developed for windowpane during World War II, but declined shortly thereafter. Commercial landings peaked at less than 360,000 pounds in 1945.

The decline in abundance of other flatfish species, particularly the yellowtail flounder, has prompted commerical vessels to land greater numbers of the windowpane in recent years. New Bedford, Massachusetts, has been a center of this activity. Commercial and recreational harvests 


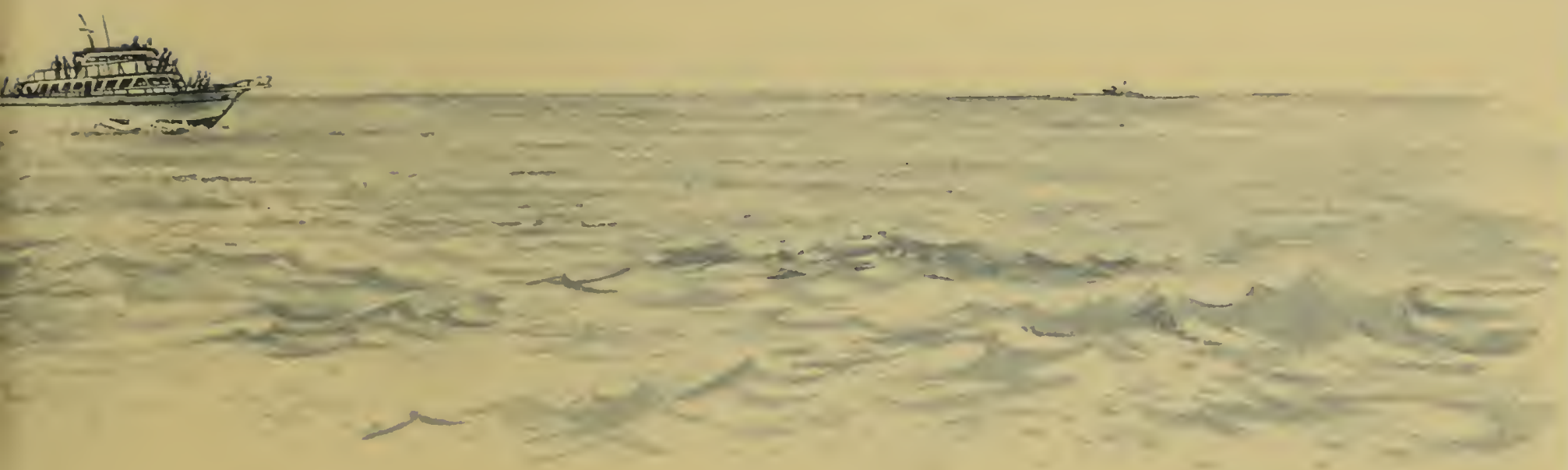

remain relatively modest, although they are increasing annually. To protect the windowpane from potential over-harvest, the Massachusetts Division of Marine Fisheries maintains a minimum legal size limit for this species.

\section{Angling and Handling Tips}

$\mathrm{T}$ he windowpane has traditionally held only modest interest for anglers due to the difficulty in removing fillets from its thin body. In recent years, anglers have directed increasing attention toward this flavorful species because it continues to be available while other larger inshore flatfish species become scarce.

Anglers catch windowpanes using gear and methods similar to those used for other flatfish, such as the summer flounder. Many anglers prefer light tackle, such as a medium-action spinning rod strung with 10- to 15-pound test line. Line this heavy is necessary because of the likelihood of occasionally hooking other, somewhat larger species when fishing for windowpane. Size \#1 hooks with snells or leaders can be tied to the line 12 to 18 inches below a sinker. A variety of baits can be used, such as sandworms, bloodworms, pieces of clams or even small strips of squid. However, fish strips or sand eels, retrieved along the bottom, may provide the greatest angling success. Hooks should be checked frequently in order to keep bait fresh.

Some anglers fillet this species, while others do not because they do not want to waste the meat near the frame bones. They simply scale, gut, and remove the head from the fish. Whole, cleaned windowpane are typicaly floured and pan fried.

Filleting the windowpane may be a greater challenge than catching it. Use a thin-bladed knife to fillet this species. Cut behind the head and gill and slice down the lateral line to the tail. A raised ridge of bones running from the head to the tail along the mid-lateral portion of the body naturally divides the fillet on either side into upper and lower halves. To remove these fillets, position the fish with its tail toward you. Cut along the frame, removing the fillet from the mid-line bones to the dorsal fin; use the same method to remove the lower fillet from the same side. Turn the fish over and repeat. Removing these fillets so that little meat is wasted requires experience. With practice, each fish will provide 4 thin but tasty pieces of meat.

Windowpane fillets have a mild, sweet flavor and are excellent when prepared with any flatfish recipe. Try the two easy, quick methods of cooking on the following page.

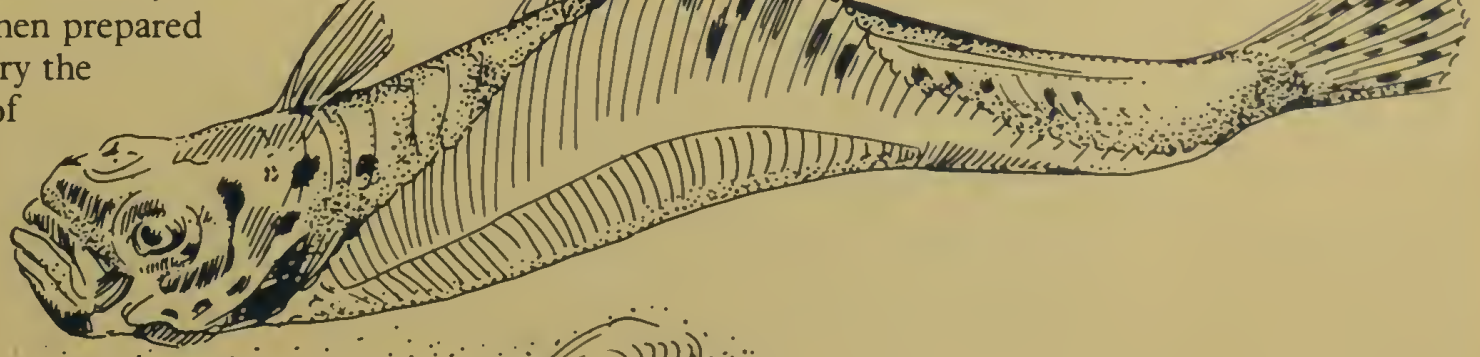


1) Dredge fillets in flour. Saute them in butter or margarine until lightly browned, turning each fillet once during cooking. Season to taste and sprinkle with parsley and lemon juice.

2) Quick broil under high heat for several minutes, basting with butter, or margarine. Add parsley and serve with a quarter wedge of lime.

Michael R. Ross and Laura A. Thorpe

Department of Forestry and Wildlife Management University of Massachusetts

Robert C. Bragi

Cooperative Extension

University of Massachusetts

Supported by Federal Aid in Sport Fish Restoration Act, through the Massachusetts Division of Marine Fisheries, Department of Fisheries, Wildlife, and Environmental Law Enforcement, Executive Office of Environmental Affairs.

Produced by Cooperative Extension Communications Center. Liz Scott, design; Nancy Haver, Roy Lewando, illustration. University of Massachusetts, United States Department of Agriculture, and Massachusetts counties cooperating. Issued by E. Bruce MacDougall, Dean, in furtherance of the Acts of May 8 and June 30,1914. Cooperative Extension offers equal opportunity in programs and employment. When a product name is mentioned, no discrimination is implied against similar or equivalent products. CR 60:12/87-10M

This publication is part of the Marine Recreational Fisheries series, available from the Division of Marine Fisheries, 100 Cambridge Street, Boston, MA 02202.

$176 \quad 106$ 

